\title{
Global and Regional Ecosystem Modeling: Databases of Model Drivers and Validation Measurements
}

R. J. Olson, K. R. Johnson, D. L. Zheng, and J. M. O. Scurlock

Environmental Sciences Division

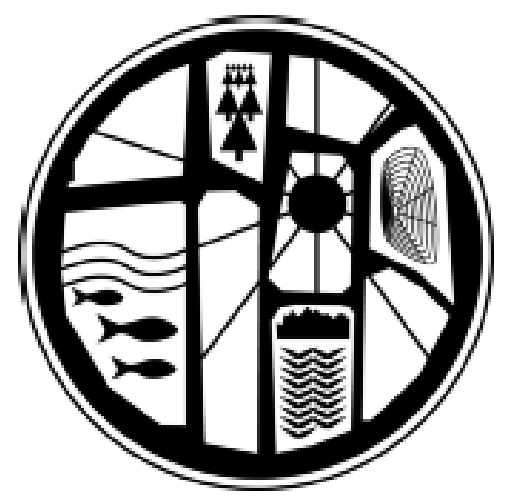




\section{DOCUMENT AVAILABILITY}

Reports produced after January 1, 1996, are generally available free via the U.S. Department of Energy (DOE) Information Bridge.

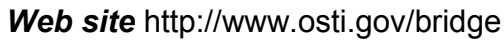

Reports produced before January 1, 1996, may be purchased by members of the public from the following source.

National Technical Information Service

5285 Port Royal Road

Springfield, VA 22161

Telephone 703-605-6000 (1-800-553-6847)

TDD 703-487-4639

Fax 703-605-6900

E-mail info@ntis.fedworld.gov

Web site http://www.ntis.gov/support/ordernowabout.htm

Reports are available to DOE employees, DOE contractors, Energy Technology Data Exchange (ETDE) representatives, and International Nuclear Information System (INIS) representatives from the following source.

Office of Scientific and Technical Information

P.O. Box 62

Oak Ridge, TN 37831

Telephone 865-576-8401

Fax 865-576-5728

E-mail reports@adonis.osti.gov

Web site http://www.osti.gov/contact.html

This report was prepared as an account of work sponsored by an agency of the United States Government. Neither the United States Government nor any agency thereof, nor any of their employees, makes any warranty, express or implied, or assumes any legal liability or responsibility for the accuracy, completeness, or usefulness of any information, apparatus, product, or process disclosed, or represents that its use would not infringe privately owned rights. Reference herein to any specific commercial product, process, or service by trade name, trademark, manufacturer, or otherwise, does not necessarily constitute or imply its endorsement, recommendation, or favoring by the United States Government or any agency thereof. The views and opinions of authors expressed herein do not necessarily state or reflect those of the United States Government or any agency thereof. 
ORNL/TM-2001/196

ENVIRONMENTAL SCIENCES DIVISION

\title{
GLOBAL AND REGIONAL ECOSYSTEM MODELING: DATABASES OF MODEL DRIVERS AND VALIDATION MEASUREMENTS
}

\author{
R. J. Olson \\ Environmental Sciences Division \\ Oak Ridge National Laboratory \\ P.O. Box 2008 \\ Oak Ridge, TN 37831-6407 \\ K. R. Johnson \\ Institute of Environmental Science \\ University of Miami, Ohio \\ Oxford, OH 45056 \\ D. L. Zheng \\ Department of Geography \\ University of Maryland \\ LeFrak Hall, Room 2181 \\ College Park, MD 20742-8225 \\ J. M. O. Scurlock \\ Environmental Sciences Division \\ Oak Ridge National Laboratory \\ P.O. Box 2008 \\ Oak Ridge, TN 37831-6407
}

Date Published: December 2001

This work was funded by the Terrestrial Ecosystem Program of the U.S. National Aeronautics and Space Administration

(NASA Reference Number TE/99-0005 under

Interagency Agreement number 2013-M164-A1 with the U.S. Department of Energy)

Prepared by the

OAK RIDGE NATIONAL LABORATORY

Oak Ridge, Tennessee 37831 managed by

UT-BATTELLE, LLC

for the

U.S. DEPARTMENT OF ENERGY

under contract DE-AC05-00OR22725 


\section{CONTENTS}

\section{Page}

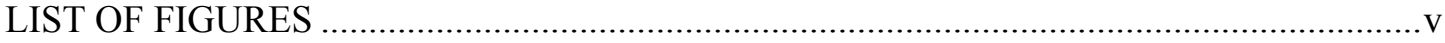

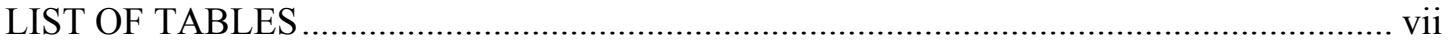

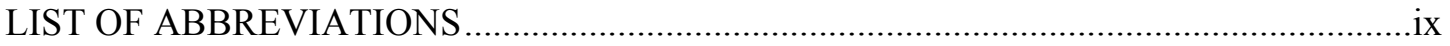

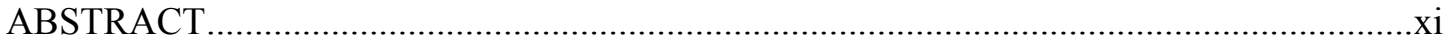

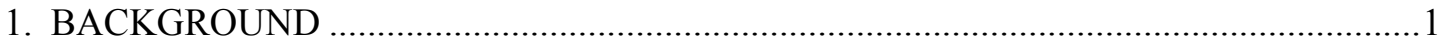

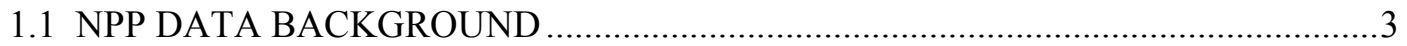

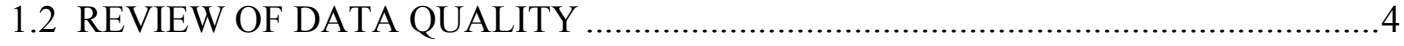

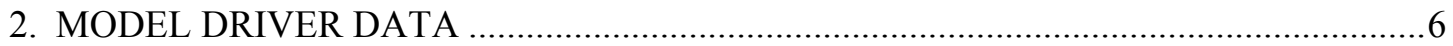

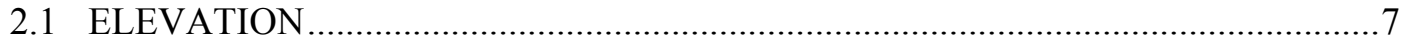

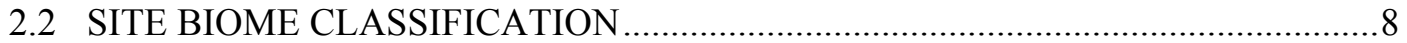

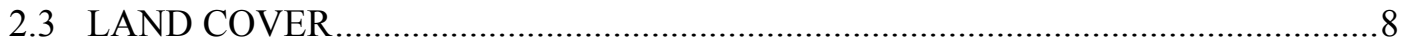

2.4 CLIMATE

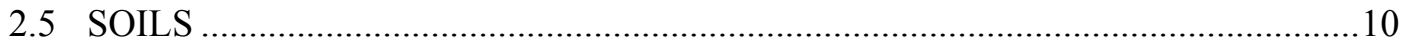

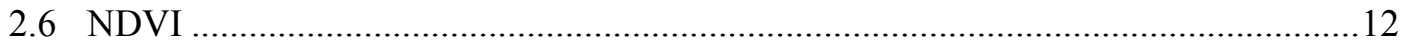

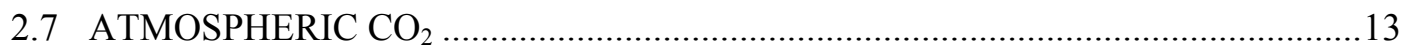

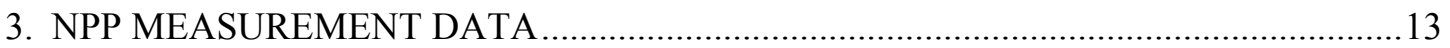

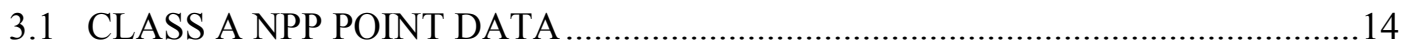

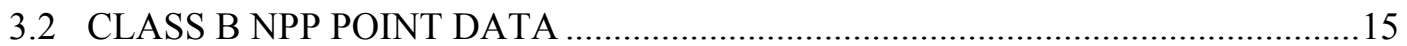

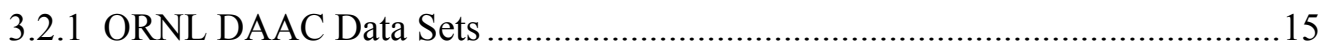

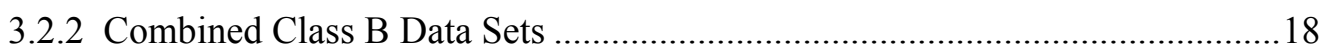

3.2.3 Additional Class B Data Sets ..................................................................... 18

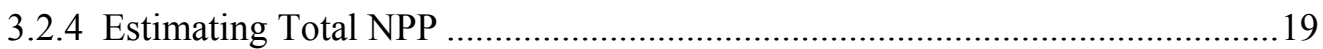

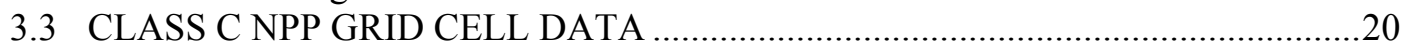

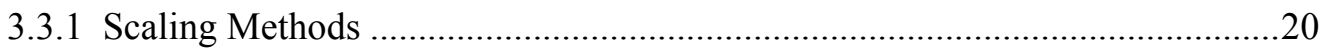

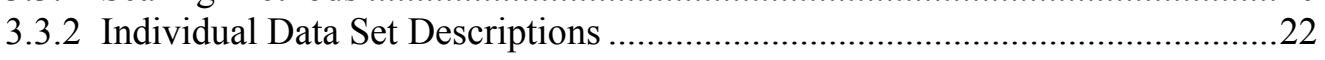

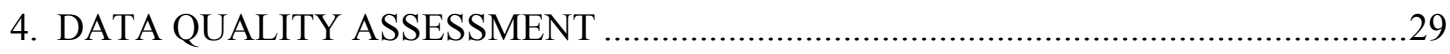

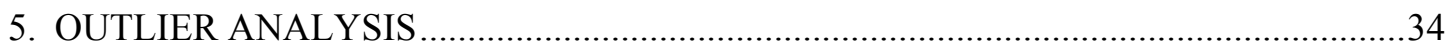

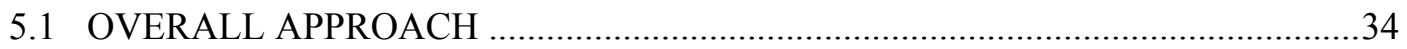

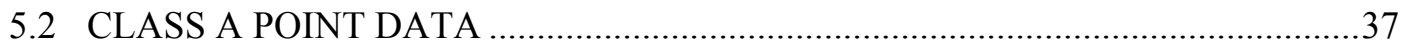

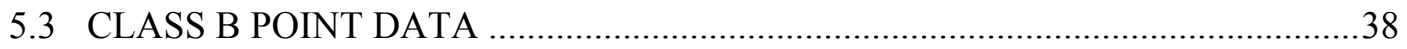

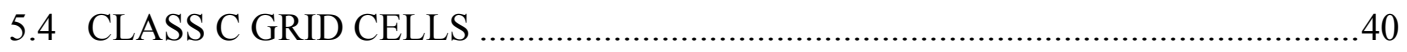

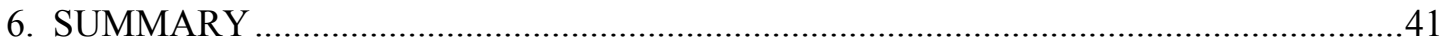

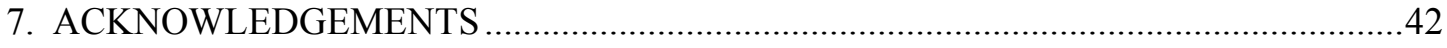

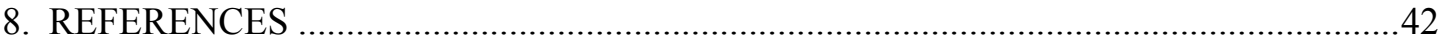

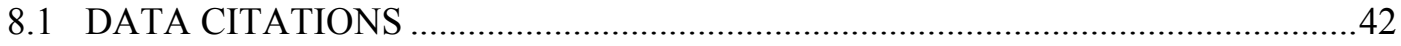

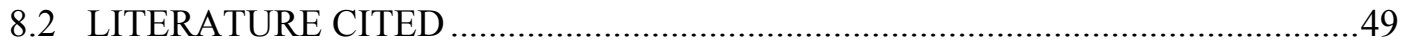


CONTENTS (continued)

Page

APPENDIX A: CONTRIBUTORS TO THE NPP DATABASE AND PARTICIPANTS

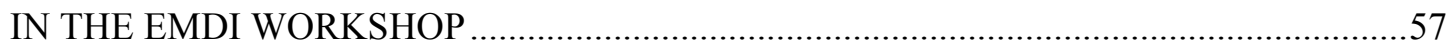

APPENDIX B: CLASS C $0.5^{\circ}$ GRID CELL DATA FORMAT AND

PROCESSING NOTES

APPENDIX C: STATISTICAL ANALYSIS OF RATIOS OF BELOW GROUND NET PRIMARY PRODUCTIVITY TO TNPP TO DERIVE CONVERSIONS TO ESTIMATE

TOTAL NPP

APPENDIX D: DATA SETS OF MODEL DRIVER AND VALIDATION

VARIABLES . 


\section{LIST OF FIGURES}

Figure

Page

1 Global distribution of Class A (Fig. 1a) and Class B (Fig. 1b) sites and Class C grid cells (Fig. 1c) .5

2 Mean NPP and number of measurements for aggregated biomes for Class A, $\mathrm{B}$, and $\mathrm{C}$ data sets

3 Mean ratio and standard error of below ground (BNPP) net primary productivity to total NPP for aggregated biomes .

4 Site-specific elevation versus elevation derived from global DEM for 817

Class B sites with elevation acquired from literature 30

5 Site-specific precipitation versus precipitation derived from global climate database for Class A sites with precipitation acquired from literature

6 Site-specific temperature versus temperature derived from global climate database for Class A sites with temperature acquired from literature.

$7 \quad$ Site-specific precipitation versus precipitation derived from global climate database for Class B sites with precipitation acquired from literature

8 Site-specific temperature versus temperature derived from global climate database for Class B sites with temperature acquired from literature 


\section{LIST OF TABLES}

Table

Page

1 Summary of activities in the development of global net primary productivity (NPP) data sets for use in model development and other ecological research ..........2

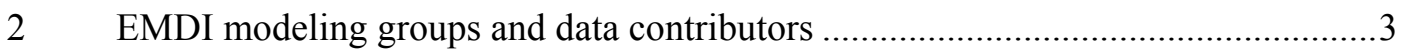

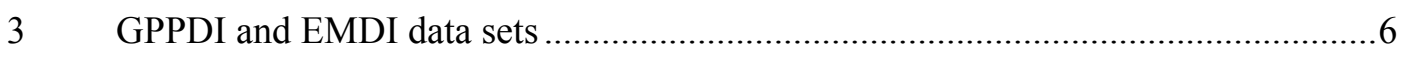

4 Biome categories for Class A and B sites as defined at the EMDI I Workshop........8

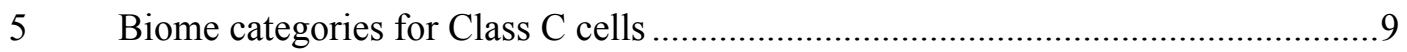

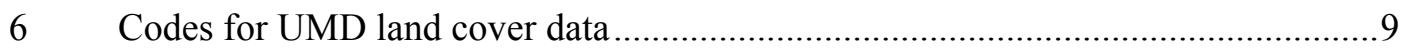

$7 \quad$ EMDI soil parameters extracted from the IGBP Soils Database .............................11

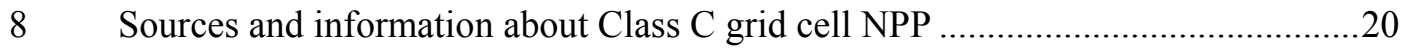

9 Summary of the availabilities of ANPP and TNPP in the 16 original studies ( $y=y e s, n=n o$, and $\mathrm{e}=$ estimated) along with NPP estimation and scaling methods

10 Flags' names, descriptions, and weights used for Class A records .37

11 Class A sites identified as outliers by participants in the EMDI I workshop ...........38

12 Flags' names, descriptions, and weights used for Class B records.........................39

13 Flags' names, descriptions, and weights used for Class $\mathrm{C}$ records.........................40

14 Maturation of the EMDI I data set.................................................................. 41

B.1 File layout, variables, and units of measure for the Class $\mathrm{C} 0.5^{\circ}$ grid cell measurements

C.1 Ratios of below ground to total NPP estimates summarized by biome.

C.2 Results of general linear models procedure on dependent variable:

BNPP:TNPP

C.3 Duncan's multiple range test for variable BNPP:TNPP with alpha $=0.05$, $\mathrm{df}=544, \mathrm{MSE}=0.017035$ 


\section{LIST OF TABLES (continued)}

Table

Page

D.1 Maturation of the ecosystem model-data intercomparison database.

D.2 Descriptions of data sets where $\mathrm{xxx}$ in data set name indicates the number of observations in the data set, e.g., 81, 933, and 1627 for Class A, B, and C sets, respectively

D.3 Model driver location information derived from site-specific sources.....................75

D.4 Model driver site soils information derived from site-specific sources...................75

D.5 Model driver site vegetation information derived from site-specific sources .........75

D.6 Model driver monthly temperature (Tmax, Tmin) and precipitation climate data from site-specific sources for 38 Class A sites, averaging 40 years of

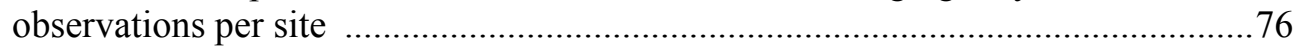

D.7 Model driver summary information derived from global sources .........................76

D.8 Model driver land cover information derived from global sources .........................77

D.9 Model driver soils information derived from global sources ...............................78

D.10 Model driver average monthly NDVI information derived from global sources ....78

D.11 Model driver 30-year average monthly climate information derived from global sources...

D.12 Model driver atmospheric carbon dioxide information derived from global sources.....

D.13 Model driver 95-year transient climate information derived from global sources

D.14 Model validation NPP information derived from site-specific sources.....

D.15 Model validation outlier flags derived from site-specific reviews

D.16 Model validation mean NPP information derived from site-specific data that passed outlier analysis

D.17 Model validation driver information derived from a variety of sources. 


\section{LIST OF ABBREVIATIONS}

\begin{tabular}{|c|c|}
\hline AET & actual evapotranspiration \\
\hline ANPP & aboveground net primary productivity \\
\hline AVHRR & Advanced Very High Resolution Radiometer \\
\hline $\mathrm{BA}$ & basal area \\
\hline BAHC & Biospheric Aspects of the Hydrological Cycle \\
\hline BNPP & below ground net primary productivity \\
\hline CDIAC & Carbon Dioxide Information and Analysis Center \\
\hline $\mathrm{CO} 2$ & carbon dioxide \\
\hline DAAC & Distributed Active Archive Center \\
\hline DEM & Digital Elevation Model \\
\hline DGVM & Dynamic Global Vegetation Model \\
\hline DIS & Data and Information System \\
\hline DSMW & Digital Soil Map of the World \\
\hline EBL & evergreen broad-leaf \\
\hline EMDI & Ecosystem Model-Data Intercomparison \\
\hline ENL & evergreen needle-leaf \\
\hline EOS & Earth Observing System \\
\hline ETM & Enhanced Thematic Mapper \\
\hline FAO & Food and Agriculture Organisation of the UN \\
\hline FIA & Forest Inventory and Analysis \\
\hline FLUXNET & Flux Network \\
\hline GAIM & Global Analysis, Interpretation, and Modelling \\
\hline GCMD & Global Change Master Directory \\
\hline GCOS & Global Climate Observing System \\
\hline GCTE & Global Change and Terrestrial Ecosystems \\
\hline GLOBE & Global Land One-km Base Elevation \\
\hline GNET & Global Network of Environment and Technology \\
\hline GOES & Geostationary Operational Environmental Satellite \\
\hline GOFC & Global Observation of Forest Cover \\
\hline GPPDI & Global Primary Production Data Initiative \\
\hline GTOS & Global Terrestrial Observing System \\
\hline IBP & International Biological Programme \\
\hline ICSU & International Council of Scientific Unions \\
\hline IGBP & International Geosphere-Biosphere Programme \\
\hline IGBP-DIS & International Geosphere-Biosphere Programme - Data and Information System \\
\hline IGOS & Integrated Global Observing Strategy \\
\hline ILTER & International Long Term Ecological Research \\
\hline ISRIC & International Soil Reference and Information Centre \\
\hline LAI & leaf area index \\
\hline LANDSAT & Land Remote Sensing Satellite \\
\hline LUCC & Land Use and Cover Change \\
\hline MAE & mean absolute error \\
\hline MLRA & Major Land Resource Area \\
\hline MODIS & Moderate Resolution Imaging Spectroradiometer \\
\hline NASA & National Aeronautics and Space Administration (U.S.A.) \\
\hline
\end{tabular}




\section{LIST OF ABBREVIATIONS (continued)}

$\begin{array}{ll}\text { NASS } & \text { National Agricultural Statistics Service } \\ \text { NCEAS } & \text { National Center for Ecological Analysis and Synthesis } \\ \text { NDVI } & \text { Normalized Difference Vegetation Index } \\ \text { NE } & \text { normalized error } \\ \text { NEP } & \text { net ecosystem productivity } \\ \text { NFI } & \text { National Forest Inventory } \\ \text { NOAA } & \text { National Oceanic and Atmospheric Administration (U.S.A.) } \\ \text { NPP } & \text { net primary productivity } \\ \text { ORNL } & \text { Oak Ridge National Laboratory (U.S.A.) } \\ \text { OTTER } & \text { Oregon Transect Ecosystem Research Project } \\ \text { PAL } & \text { Pathfinder AVHRR Land (data set) } \\ \text { PAR } & \text { photosynthetically active radiation } \\ \text { PI } & \text { Principal Investigator } \\ \text { PIK } & \text { Potsdam Institute for Climate Impact Research } \\ \text { PNW } & \text { Pacific Northwest } \\ \text { PR } & \text { Precipitation Radar } \\ \text { QA } & \text { quality assessment } \\ \text { QC } & \text { quality control } \\ \text { SCS } & \text { USDA Soil Conservation Service } \\ \text { STATSGO } & \text { State Soil Geographic } \\ \text { TEM } & \text { Terrestrial Ecosystem Model } \\ \text { Terra } & \text { Earth Observation Satellite - Land } \\ \text { TM } & \text { Thematic Mapper } \\ \text { TNPP } & \text { total net primary productivity } \\ \text { TPB } & \text { total plant biomass } \\ \text { UMD } & \text { University of Maryland } \\ \text { UNEP } & \text { UN Environmental Programme } \\ \text { USGCRP } & \text { US Global Change Research Program } \\ \text { USGS } & \text { United States Geological Survey } \\ \text { VEMAP } & \text { Vegetation/Ecosystem Modeling and Analysis Project } \\ \text { WISE } & \text { World Inventory of Soil Emission Potentials } \\ \text { WMO } & \text { World Meteorological Organisation } \\ & \end{array}$




\begin{abstract}
Olson, R. J., K. R. Johnson, D. L. Zheng, and J. M. O. Scurlock. 2001. Global and Regional Ecosystem Modeling: Databases of Model Drivers and Validation Measurements. ORNL/TM2001/196. Oak Ridge National Laboratory, Oak Ridge, Tenn.

Understanding global-scale ecosystem responses to changing environmental conditions is important both as a scientific question and as the basis for making policy decisions. The confidence in regional models depends on how well the field data used to develop the model represent the region of interest, how well the environmental model driving variables (e.g., vegetation type, climate, and soils associated with a site used to parameterize ecosystem models) represent the region of interest, and how well regional model predictions agree with observed data for the region. To assess the accuracy of global model forecasts of terrestrial carbon cycling, two Ecosystem Model-Data Intercomparison (EMDI) workshops were held (December 1999 and April 2001). The workshops included 17 biogeochemical, satellite-driven, detailed process, and dynamic vegetation global model types. The approach was to run regional or global versions of the models for sites with net primary productivity (NPP) measurements (i.e., not fine-tuned for specific site conditions) and analyze the model-data differences. Extensive worldwide NPP data were assembled with model driver data, including vegetation, climate, and soils data, to perform the intercomparison.
\end{abstract}

This report describes the compilation of NPP estimates for 2,523 sites and 5,164 0.5 -grid cells under the Global Primary Production Data Initiative (GPPDI) and the results of the EMDI review and outlier analysis that produced a refined set of NPP estimates and model driver data. The EMDI process resulted in 81 Class A sites, 933 Class B sites, and 3,855 Class C cells derived from the original synthesis of NPP measurements and associated driver data. Class A sites represent well-documented study sites that have complete aboveground and below ground NPP measurements. Class B sites represent more numerous "extensive" sites with less documentation and site-specific information available. Class C cells represent estimates of NPP for $0.5^{\circ}$-grid cells for which inventory, modeling, or remote-sensing tools were used to scale up the point measurements. Documentation of the content and organization of the EMDI databases are provided.

The first EMDI workshop demonstrated that model-data intercomparison is an important direction in regional and global model evaluation, but one that is an extraordinarily complex task. Comparing the NPP field measurements with an average NPP from an ensemble of model outputs provided a unique method to improve NPP data, model driver data, and model processes. Initial results showed general agreement between model predictions of NPP and field measurements of NPP but with obvious differences that indicated areas for potential data and model improvement. A second EMDI workshop, held in 2001, more fully analyzed the differences between measured NPP and model outputs.

The Global Analysis, Interpretation, and Modeling Task Force of the International GeosphereBiosphere Programme sponsored the EMDI Workshops; the National Center for Ecological Analysis and Synthesis (NCEAS) provided support for data organization and distribution; and the Terrestrial Ecology Program within NASA's Office of Earth Science (U.S. National Aeronautics and Space Administration, Office of Earth Science, Terrestrial Ecology Program, Activity No. 46WM16401) supported the NPP data compilation. 


\section{BACKGROUND}

Progress in modeling the global carbon cycle was previously inhibited by the lack of adequate observational data for model parameterization and validation, such as net primary productivity (NPP) and its individual components from field measurements (Scurlock et al. 1999). This problem came to light when the International Geosphere-Biosphere Programme (IGBP) project on Global Analysis, Interpretation, and Modeling (GAIM) held global NPP model intercomparison meetings in 1994 and 1995 at the Potsdam Institute for Climate Impact Research (PIK), Germany (Hibbard and Sahagian, 1998). The PIK workshops called specifically for the development of a publicly available database of NPP estimates (Lurin et al. 1994). More recently, the Vegetation/Ecosystem Modeling and Analysis Project (VEMAP) (Schimel et al. 1997) cited similar difficulties in comparing model predictions with currently available NPP estimates, an analysis of terrestrial carbon sinks cited the need for additional data to refine model constraints (Fan et al. 1998), and an overview of the variety of data for understanding the carbon cycle emphasized the value of field measurement of carbon fluxes (Canadell et al. 2000).

To assess the accuracy of global model forecasts of terrestrial carbon cycling, two Ecosystem Model-Data Intercomparison (EMDI) workshops were held at the University of New Hampshire, Durham, New Hampshire, U.S.A., December 5-8, 1999, and at the National Center for Ecological Analysis and Synthesis (NCEAS), Santa Barbara, California, U.S.A., April 18-21, 2001. The approach was to run regional or global versions of the models for sites with NPP measurements (i.e., not fine-tuned for specific site conditions) and analyze the model-data differences. The EMDI Workshops were possible because of the cumulative progress in compiling complete and consistent NPP data.

Activities leading to EMDI included the Global Primary Production Data Initiative (GPPDI), three NPP working groups sponsored by U.S. NCEAS, and two NPP projects at the Oak Ridge National Laboratory [ORNL Principal Investigator (PI) R. J. Olson and the University of Maryland (UMD) PI S. D. Prince] funded by the National Aeronautics and Space Administration (NASA) Terrestrial Ecosystems Program. GPPDI was established as an activity of the IGBP Data and Information System, a coordinated international program to improve worldwide estimates of terrestrial NPP for parameterization, calibration, and validation of NPP models at various scales (Prince et al. 1995). Under the NASA funding, 61 site-specific NPP data sets were compiled (Scurlock and Olson 2001) with grassland sites constituting over half the collection (Scurlock et al. 2001). Eight multi-site data sets were also compiled containing over NPP estimates for 1700 sites. Methods for extrapolating from point measurements to grid cells were reviewed and used to estimate NPP for croplands (Prince et al. 2000) and other biomes (Zheng et al. 2001). The NPP data are available online through the NASA-funded Distributed Active Archive Center (DAAC) at ORNL.

Under the auspices of GPPDI, a series of three Working Groups were held at NCEAS, Santa Barbara, Calif., between December 1997 and October 1998. The objectives were to take extensive but incomplete data sets and make them usable for analyses and models by estimating total NPP in a consistent manner, for points and for large-grid cells:

http://www.nceas.ucsb.edu (look for Research Projects, then "Prince")

http://daac.ornl.gov/NPP/html_docs/nceas_des.html

The NPP data compiled by the NCEAS Working Groups and other GPPDI activities were used for the EMDI activity. The GPPDI assembled more than 7500 estimates of NPP globally from 
ecological sites as well as estimates of NPP for regularly gridded regions using agricultural and forestry statistics that have high spatial density over those regions. This represents a more comprehensive database of measurements than has previously existed. The GPPDI data were analyzed to extract a subset of NPP data suitable for the EMDI workshops. Model driver data (e.g., vegetation type, climate, and soils associated with a site used to parameterize ecosystem models) were compiled for the set of EMDI data, and extensive review of the combined NPP and driver data was conducted. The sequence of NPP activities culminating in the EMDI Workshops is summarized in Table 1. The set of activities described above resulted in the publication of 75 NPP data sets (see Sect. 8.1 for a list of the data citations).

Table 1. Summary of activities in the development of global net primary productivity (NPP) data sets for use in model development and other ecological research

\begin{tabular}{|c|c|c|c|}
\hline Year & Activity & Accomplishment & NPP data \\
\hline 1993-95 & $\begin{array}{l}\text { Model inter- } \\
\text { comparison } \\
\text { workshops - PIK }\end{array}$ & $\begin{array}{l}\text { Established need for global } \\
\text { NPP data to compare to } \\
\text { models }\end{array}$ & $\begin{array}{l}400 \text { NPP values compiled } \\
\text { from participants }\end{array}$ \\
\hline 1995 & $\begin{array}{l}\text { Global primary } \\
\text { productivity data } \\
\text { initiative (GPPDI) }\end{array}$ & $\begin{array}{l}\text { Established GPPDI with } \\
\text { steering committee that } \\
\text { documented need for global } \\
\text { NPP data to compare to } \\
\text { models }\end{array}$ & \\
\hline 1996 Dec & $\begin{array}{l}\text { NPP Workshop - } \\
\text { IGBP-DIS, Cincinnati }\end{array}$ & $\begin{array}{l}\text { Reviewed progress, drafted } \\
\text { proposal to NCEAS; } \\
\text { estimated NPP data available } \\
\text { for } 100-300 \text { sites }\end{array}$ & Class A - 31 sites \\
\hline 1996-2001 & $\begin{array}{l}\text { Net primary product- } \\
\text { ivity projects - NASA } \\
\text { Terrestrial Ecosystems } \\
\text { Program }\end{array}$ & $\begin{array}{l}\text { NPP projects at ORNL and } \\
\text { UMD, renewed in } 1999\end{array}$ & $\begin{array}{l}\text { GPPDI NPP data set: } \\
\text { - Class A - } 162 \text { sites } \\
\text { - Class B - } 2363 \text { sites } \\
\text { - Class C - } 5164 \text { cells }\end{array}$ \\
\hline $\begin{array}{l}1997 \text { Dec; } \\
1998 \text { Feb; } \\
1998 \text { Oct }\end{array}$ & $\begin{array}{l}\text { NPP working groups - } \\
\text { NCEAS, Santa } \\
\text { Barbara }\end{array}$ & $\begin{array}{l}\text { Published selected NPP data } \\
\text { for boreal, grassland, } \\
\text { tropical, and crop systems; } \\
\text { created rules for estimating } \\
\text { NPP from partial data }\end{array}$ & $\begin{array}{l}\text { NPP data sets: } \\
\text { - boreal forest - } 69 \text { sites } \\
\text { - tropical forest - } 62 \text { sites } \\
\text { - grassland - } 32 \text { sites } \\
\text { - crops - } 1195 \text { cells } \\
\text { - temperate forests - } 247 \text { cells }\end{array}$ \\
\hline $\begin{array}{l}1999 \mathrm{Dec} ; \\
2001 \mathrm{Apr}\end{array}$ & $\begin{array}{l}\text { Ecosystem model-data } \\
\text { intercomparison } \\
\text { workshops (EMDI) - } \\
\text { GAIM/NCEAS }\end{array}$ & $\begin{array}{l}\text { Compared model outputs } \\
\text { with field measurements }\end{array}$ & $\begin{array}{l}\text { EMDI NPP data set: } \\
\text { - Class A - } 81 \text { sites } \\
\text { - Class B - } 933 \text { sites } \\
\text { - Class C - } 3837 \text { cells }\end{array}$ \\
\hline
\end{tabular}

The participating modeling groups represented a broad range of approaches to treating terrestrial carbon dynamics. Groups employing satellite-driven radiation-interception models, ecosystem biogeochemical models with monthly time steps, detailed process models with hourly time steps, and static vegetation and dynamic vegetation variants of these completed runs and were present at the workshop. Each modeling group was provided basic model drivers for the sites and regions or could use their own resources for producing model simulations. The NPP measurements were not provided to the modelers until they submitted their simulation results. The modeling groups and data contributors who participated in EMDI are shown in Table 2 and Appendix A. 
Table 2. EMDI modeling groups and data contributors

\begin{tabular}{|c|c|c|}
\hline Model name & Modelers & Institution, country \\
\hline AVIM & Jinjun Ji & Institute of Atmospheric Physics, China \\
\hline BGC & Peter Thornton & University of Montana, U.S.A. \\
\hline CARAIB & Bernard Nemry & University of Liege, Belgium \\
\hline CENTURY & Bill Parton & Colorado State University, U.S.A. \\
\hline GLO-PEM & Steve Prince, Daolan Zheng & University of Maryland, U.S.A. \\
\hline GTEC & Mac Post, Tony King & Oak Ridge National Laboratory, U.S.A. \\
\hline IBIS & Chris Kucharik, Jon Foley & University of Wisconsin, U.S.A. \\
\hline LPJ & Stephen Sitch, Ben Smith & $\begin{array}{l}\text { Potsdam Institute for Climate Impact } \\
\text { Research, Germany }\end{array}$ \\
\hline PnET & John Aber & University of New Hampshire, U.S.A. \\
\hline SIB2w/carbon & Chris Field, Jörg Kaduk & Carnegie Institution, Stanford, U.S.A. \\
\hline STOMATE & $\begin{array}{l}\text { Pierre Friedlingston, Laurent } \\
\text { Kergoat }\end{array}$ & CNRS, France \\
\hline VECODE & Victor Brovkin & $\begin{array}{l}\text { Potsdam Institute for Climate Impact } \\
\text { Research, Germany }\end{array}$ \\
\hline Data & Data contributors & Institution, country \\
\hline NPP & $\begin{array}{l}\text { Jonathan Scurlock, Dick Olson, } \\
\text { Keri Johnson }\end{array}$ & Oak Ridge National Laboratory, U.S.A. \\
\hline NPP & Steve Prince, Daolan Zheng & University of Maryland, U.S.A. \\
\hline NPP & Bill Parton, Steve Del Grossa & Colorado State University, U.S.A. \\
\hline NPP & Tom Gower, Drew Feldkirchner & University of Wisconsin-Madison, U.S.A. \\
\hline NPP & Jian $\mathrm{Ni}$ & University of Beijing, China \\
\hline NPP & Larry Tieszen & USGS EROS Data Center, U.S.A. \\
\hline NPP & Jennifer Jenkins & USDA Forest Service, U.S.A. \\
\hline Elevation & Rob Braswell & University of New Hampshire, U.S.A. \\
\hline Soil properties & Dick Olson, Keri Johnson & Oak Ridge National Laboratory, U.S.A. \\
\hline Land cover & Steve Prince, Robb Wright & University of Maryland, U.S.A. \\
\hline Monthly NDVI & Rob Braswell & University of New Hampshire, U.S.A. \\
\hline Atmospheric $\mathrm{CO}_{2}$ & Bob Cushman & $\begin{array}{l}\text { ORNL Carbon Dioxide Information and } \\
\text { Analysis Center, U.S.A. }\end{array}$ \\
\hline $\begin{array}{l}30 \text {-year average } \\
\text { monthly climate }\end{array}$ & Wolfgang Cramer, Stephen Sitch & $\begin{array}{l}\text { Potsdam Institute for Climate Impact } \\
\text { Research, Germany }\end{array}$ \\
\hline $\begin{array}{l}\text { Actual monthly } \\
\text { climates }\end{array}$ & Wolfgang Cramer, Stephen Sitch & $\begin{array}{l}\text { Potsdam Institute for Climate Impact } \\
\text { Research, Germany }\end{array}$ \\
\hline
\end{tabular}

\subsection{NPP DATA BACKGROUND}

The GPPDI database includes NPP measurements collected over a long time period by many investigators using a variety of methods. The minimum requirements for data to be included were as follows:

- the use of one or more accepted methods to estimate aboveground or below ground NPP;

- geographical location for the study site;

- definition of biome or vegetation type; and

- a citable reference to peer-reviewed publication, symposium, or workshop proceedings; book chapter; or technical memorandum. 
The measurements of NPP were categorized as either Class A, intensively studied sites; Class B, "extensive" sites; or Class C, $0.5^{\circ}$ latitude-longitude grid cells.

Class A sites - data for Class A sites represent intensively studied or well-documented study sites (e.g., with site-specific climate, soils information, etc.) and have complete NPP measurements and good documentation. Sites include grassland, tropical forest, temperate forest, and boreal forest biomes (Fig. 1a).

Class B sites - data for Class B sites represent more numerous "extensive" sites with less documentation and site-specific information available and include study sites from many biomes compiled from existing collections of data (Fig. 1b).

Class $\mathbf{C}$ cells - data for Class $\mathrm{C}$ cells represent regional collections of $0.5^{\circ}$-grid cell sites from many biomes compiled from collections of data that have NPP estimates (Fig. 1c). The EMDI Class $\mathrm{C}$ cells represent the results of scaling up from point measurements to grid cells.

\subsection{REVIEW OF DATA QUALITY}

The NPP data have undergone several levels of review or filtering. The activities associated with the GPPDI, especially the three Working Groups funded by NCEAS, provided a literature review that resulted in selecting Class A sites. The EMDI activity provided another level of review for all the data by examining relationships between NPP estimates and associated environmental controlling variables, such as temperature and precipitation. As a results of the EMDI review, as described below and in Sect. 5, we assigned flags to each NPP estimate and selected a subset of data for the model-data intercomparison based on the flags.

The data were reviewed at the EMDI I Workshop, and a strategy was developed for additional "outlier analysis" to flag those NPP measurements that, in combination with their driver data and the NPP ensemble model values, appeared to be unrepresentative or represented conditions that the global ecosystem models did not consider (e.g., wetlands) (see Sect. 5). The EMDI Workshop participants also agreed on (1) an approach to assigning consistent biome classes to all sites, (2) standardizing latitude and longitude to two decimal places, and (3) assigning unique identifiers for locations (SITE_ID) and individual measurements (MEAS_ID) within classes for linking with model driver data and validation data.

The specific issues that were addressed include:

- Biome class consistency - The review of biome assignments was prompted in part by the problems in using the satellite-derived land cover for each site (i.e., often this represented the dominant land cover for a $1 \times 1 \mathrm{~km}$ area, not the cover for the $1 \times 1 \mathrm{~m}$ to 1 -hectare NPP measurement site).

- $\quad$ Managed sites - The EMDI modelers decided to flag and exclude likely heavily managed sites and wetlands from the EMDI comparison.

- Multiple NPP values for a site - Some sites have several NPP values, often from several vegetation types. We assume this is often a result of reporting imprecise latitude/longitude coordinates. Some Class B sites have up to 35 observed NPP values at a site. Each site was assigned an EMDI biome class and the biome of every NPP measurements at the site 

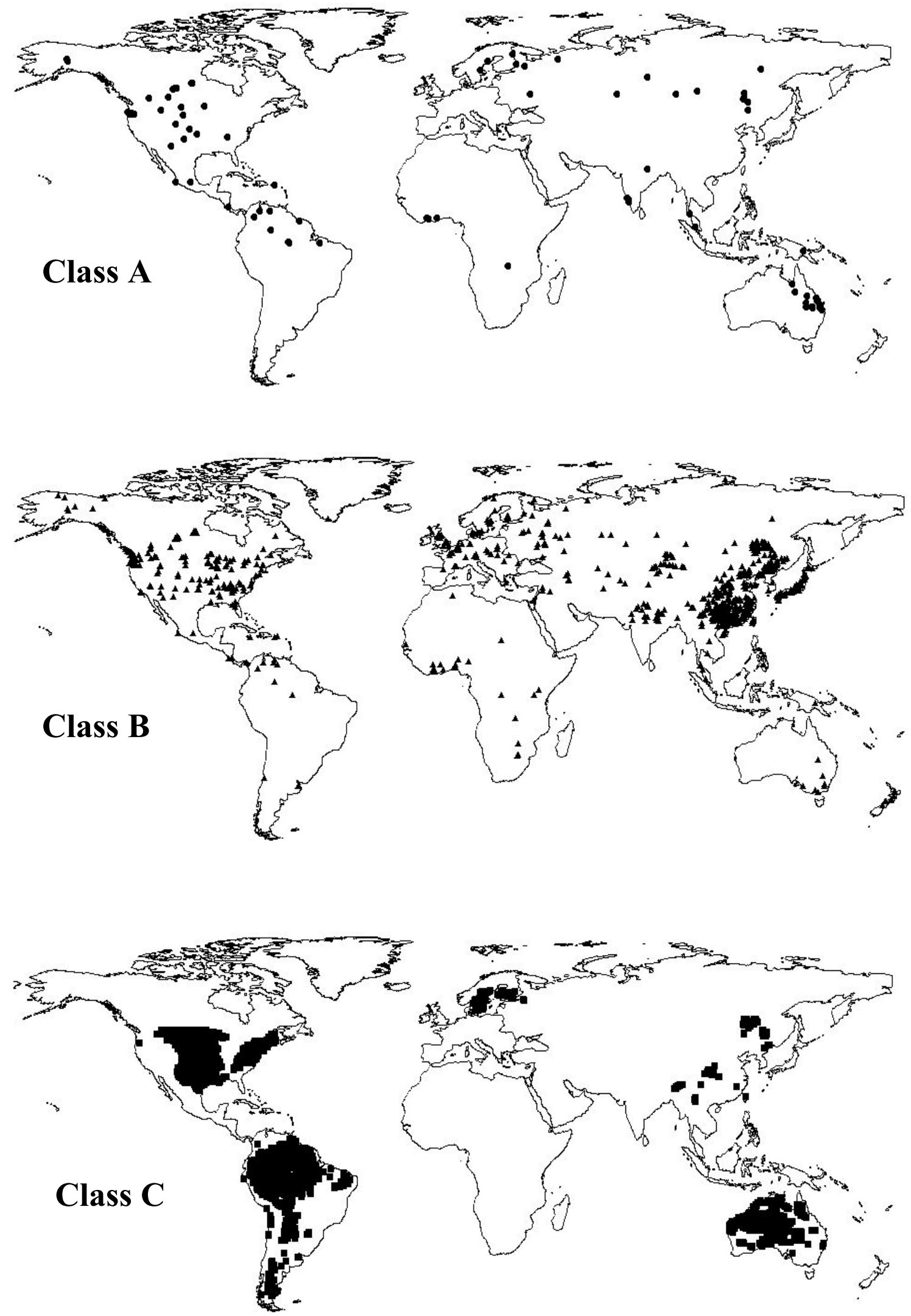

Fig. 1. Global distribution of Class A (Fig. 1a) and Class B (Fig. 1b) sites and Class C grid cells (Fig. 1c). 
reviewed. Those NPP data that were inconsistent with the site biome were flagged. This resulted in 187 Class B measurements being dropped for the EMDI activity. A few Class C cells also had multiple NPP values where data had been compiled based upon different studies.

This report describes the compilation of NPP estimates for 2,525 sites and 5,164 $0.5^{\circ}$ grid cells compiled under the GPPDI (Table 3). This report also documents the results of the EMDI review and outlier analysis that produced a refined set of NPP estimates and model driver data for the EMDI workshops. Often we estimated missing NPP components for sites using the approaches described in Appendices B and C. The EMDI process resulted in 81 Class A sites, 933 Class B sites, and 3,855 Class C cells derived from the analysis of NPP measurements and associated driver data. The average NPP for major biomes in each of the Classes is presented in Fig. 2. Documentation of the content and organization of the EMDI databases are provided in Appendix D.

Table 3. GPPDI and EMDI data sets

\begin{tabular}{ccccl}
\hline \multicolumn{2}{c}{ Number of records } & Date compiled & Description \\
\cline { 1 - 3 } Class A & Class B & Class C & October 1999 & $\begin{array}{l}\text { GPPDI NPP measurements, many sites with } \\
\text { multiple measurements }\end{array}$ \\
\hline 162 & 2,363 & $5,164^{*}$ & March 2000 & $\begin{array}{l}\text { EMDI NPP and driver data set of sites with } \\
\text { outliers excluded and means of multiple } \\
\text { measurements }\end{array}$ \\
\hline
\end{tabular}

*Data for Class C cells was expanded in October 2000.

\section{MODEL DRIVER DATA}

Model driver data (e.g., vegetation type, climate, and soils associated with a site used to parameterize ecosystem models) were compiled from global databases specifically for the EMDI workshops. The information is consistent for all sites but may represent a value for a 5-km or 5minute grid cell within which a Class A or B site is located, thus the data may not necessarily reflect the conditions at the specific site of the NPP measurement.

The same sources of driver data were used for the Class A and B data sets and an initial subset of Class $\mathrm{C}$ data; however, the driver data for the full set of Class $\mathrm{C}$ cells for EMDI II was taken from different sources than for EMDI I. Although EMDI I included a set of 2768 Class $\mathrm{C}$ grid cells, a significant increase of Class $\mathrm{C}$ grid cells was available for EMDI II and the processing was performed on the expanded set. In late 2000, the Class C data set was expanded to 5,164 cells representing 3,980 unique sites. We compared the original EMDI I driver data for 1637 cells in the U.S. Great Plains and eastern U.S. forests with the new driver data for the same cells provided with the expanded Class $\mathrm{C}$ data set to confirm that there were no significant differences between the two sets of driver data. This included using scatter plots to compare driver data from each source for soils, Normalized Difference Vegetation Index (NDVI), temperature, and precipitation and matching landcover types and biomes. Scatter plots were compared for four months (January, April, July, October) of the year for temperature, precipitation, and NDVI. We determined that the driver data for the expanded Class $\mathrm{C}$ cells were consistent with the driver data used for Classes A and B. 


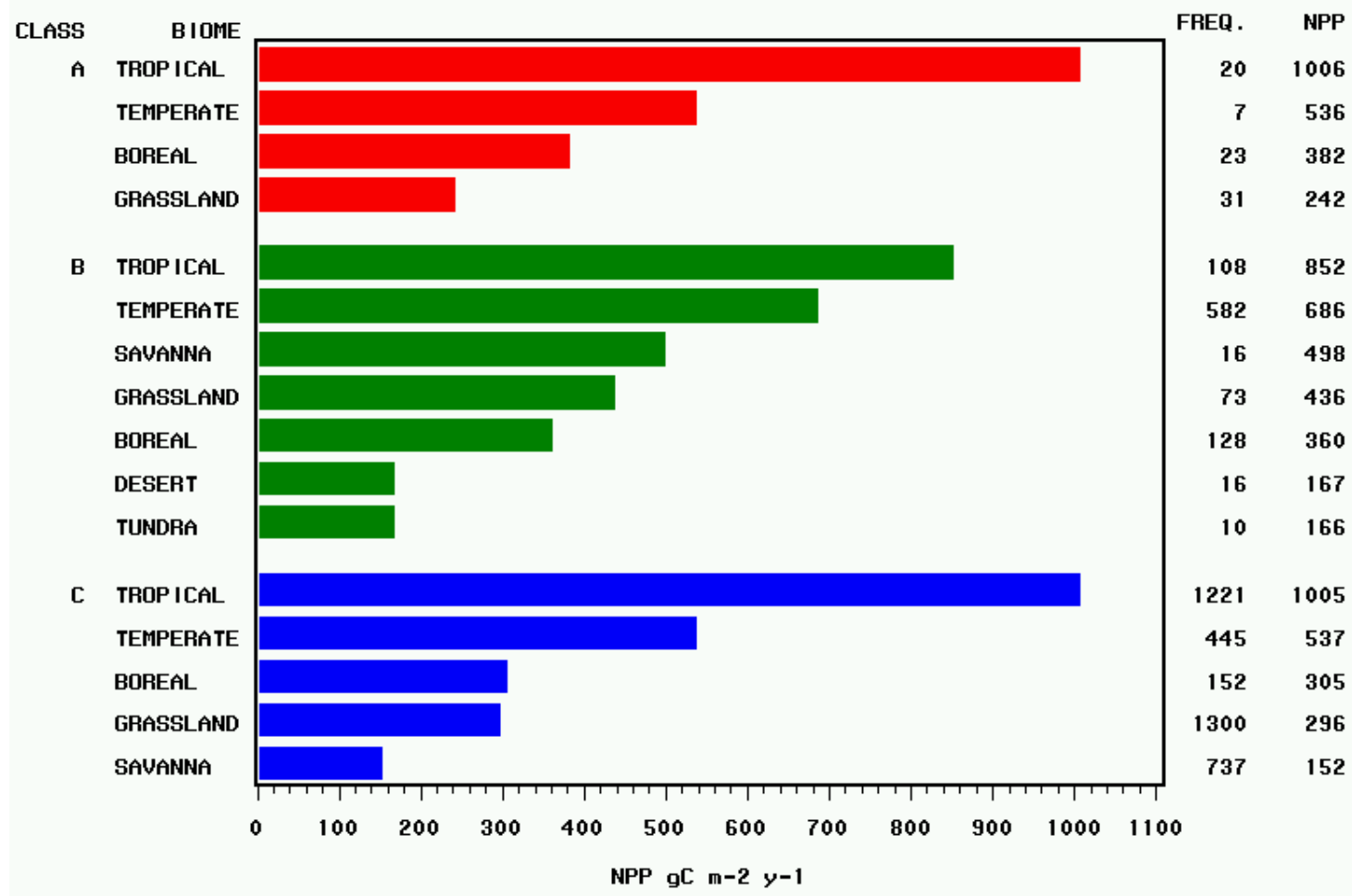

Fig. 2. Mean NPP and number of measurements for aggregated biomes for Class $A, B$, and $C$ data sets.

\subsection{ELEVATION}

For Class A and B sites, the site elevation was used when available. However, approximately $25 \%$ of Class A and $50 \%$ of Class B measurement sites lacked a site-specific record of elevation. Rob Braswell, University of New Hampshire, generated elevations using the U.S. National Geophysical Data Center's TerrainBase Digital Elevation Model (DEM), which has a 5 -minute resolution (approximately $10 \mathrm{~km}$ at the equator). Because of the limited precision of both the site coordinates and the DEM algorithm, we acknowledge that the latitude/longitude/elevation values may contain significant errors. Approximately $5 \%$ of the elevations based on the DEM had significantly negative elevations ( $>100 \mathrm{~m}$ below sea level), a likely indicator of compounded errors.

Elevations for Class $\mathrm{C}$ cells were assigned by Daolan Zheng based on an alternative 1-km DEM derived from the Global Land One-km Base Elevation (GLOBE) Project, a quality-controlled global DEM developed by the U.S. National Geophysical Data Center for International Geosphere-Biosphere Programme - Data and Information System (IGBP-DIS):

http://www.ngdc.noaa.gov/seg/topo/globe.html

Aggregation of the GLOBE DEM 1-km elevations to $0.5^{\circ}$ cells resulted in only $0.2 \%$ of cells with significantly negative elevations. The GLOBE database was not available in 1999 when the Class $\mathrm{A}$ and $\mathrm{B}$ sites were assigned elevations. 


\subsection{SITE BIOME CLASSIFICATION}

Twenty-one biome classes were defined at the EMDI workshop to represent the data and needs of the models (Table 4). Sites were assigned to a biome based on initial biome class, sub-biome, species, vegetation type, and elevation. The 21 biome types were grouped into 12 types based on similarity and the number of Class A and B sites to ensure there were enough data (at least 30 to 40 sites) within each aggregated biome to conduct the outlier detection described in Sect. 5. Heavily managed sites or sites typically not addressed by regional models, including crop, pasture, plantation, and wetland biome types, were assigned to a single "Managed" type. These sites were flagged and excluded from the EMDI exercises.

Table 4. Biome categories for Class A and B sites as defined at the EMDI I Workshop

\begin{tabular}{llcc}
\hline \multicolumn{1}{c}{ Biome type } & Aggregated biome type & \multicolumn{2}{c}{ Number of sites } \\
& & Class A & Class B \\
\hline Crops & Managed & & 14 \\
Pasture & Managed & & 17 \\
Plantation & Managed & & 27 \\
Wetland & Managed & 6 & 46 \\
Deciduous broad-leaf forest / boreal & DBL forest / boreal & 6 & 233 \\
Deciduous broad-leaf forest / temperate & DBL forest / temperate & 6 & 17 \\
Deciduous broad-leaf forest / tropical & DBL forest / tropical & 6 & 26 \\
Desert & Desert & & 29 \\
Deciduous needle-leaf forest / boreal & DNL forest / boreal & 9 & 250 \\
Evergreen broad-leaf forest / temperate & EBL forest / temperate & & 102 \\
Evergreen broad-leaf forest / tropical & EBL forest / tropical & 27 & 117 \\
Evergreen needle-leaf forest / boreal & ENL forest / boreal & 56 & 210 \\
Evergreen needle-leaf forest / temperate & ENL forest / temperate & 6 & 41 \\
Grassland / C3 & Grassland & 10 & 18 \\
Grassland / C4 temperate & Grassland & 6 & 32 \\
Grassland / C4 tropical & Grassland & 30 & 12 \\
Mediterranean & Savanna & & 49 \\
Mixed forest & Mixed forest & & 1 \\
Savanna / temperate & Savanna & & 8 \\
Savanna / tropical & Savanna & & 24 \\
Tundra & Tundra & 162 & 1317 \\
Total Records & &
\end{tabular}

Biome type for Class $\mathrm{C}$ cells was based on information obtained from or reported by each individual study. If the biome was not available (e.g., in Senegal), then we used an aggregated type based on the Hansen et al. (2000b) 1-km product as discussed in Sect. 2.3. The biomes are listed in Table 5, including the scheme that was used to consolidate the biomes into types consistent with the Class A and B aggregated biome types (Table 4).

\subsection{LAND COVER}

Land cover was extracted by Steve Prince and Robb Wright, University of Maryland, from the University of Maryland's 1-km Global Land Cover product (Hansen et al. 2000b; http://www.inform.umd.edu/geog/landcover/1km-map.html). This data set was compiled at the 
Laboratory for Global Remote Sensing Studies, housed within the Geography Department at the University of Maryland, U.S.A. (http://www.inform.umd.edu/geog/landcover/global-cover.html). Because of the limited spatial resolution of the database around coastlines (and especially islands), approximately $5 \%$ of the study sites were assigned a cover type of 0 (water).

The land cover codes and respective classes are shown in Table 6, with the abbreviations used in the data file indicated in parentheses.

Table 5. Biome categories for Class $\mathbf{C}$ cells

\begin{tabular}{llc}
\hline \multicolumn{1}{c}{ Biome type } & \multicolumn{1}{c}{ Aggregated biome type } & Number \\
\hline Arid shrubland & Shrubland & 64 \\
Bare ground & Bare ground & 7 \\
Boreal & Forest / boreal & 4 \\
Boreal conifer-dominated & ENL forest / boreal & 82 \\
Boreal forest & Forest / boreal & 66 \\
Closed shrubland & Shrubland & 1 \\
Crop & Crops & 220 \\
Deciduous forest & DBL forest / tropical & 16 \\
Evergreen forest & EBL forest / tropical & 1195 \\
Forest & Forest / temperate & 2 \\
Grass & Grassland & 2285 \\
Grassland & Grassland & 33 \\
Open shrubland & Shrubland & 520 \\
Savanna & Savanna & 69 \\
Subtropic forest & Forest / tropical & 10 \\
Temperate forest & Forest / temperate & 342 \\
Wooded grassland & Wooded grassland & 115 \\
Woodland & Forest & 2 \\
Xeric forest & Forest / xeric & 131 \\
Total & & 5164 \\
\hline
\end{tabular}

Table 6. Codes for UMD land cover data

\begin{tabular}{cl}
\hline Code & \multicolumn{1}{c}{ Class (abbreviation) } \\
\hline 0 & Water (water) \\
1 & Evergreen needleleaf forests (needle_e) \\
2 & Evergreen broadleaf forests (broad_e) \\
3 & Deciduous needleleaf forests (needle_d) \\
4 & Deciduous broadleaf forests (broad_d) \\
5 & Mixed forests (mixed) \\
6 & Woodlands (woodland) \\
7 & Wooded grasslands/ shrubs (woodgrss) \\
8 & Closed bushlands or shrublands (shrub_cl) \\
9 & Open shrublands (shrub_op) \\
10 & Grasses (grass) \\
11 & Croplands (crop) \\
12 & Bare (bare) \\
13 & Urban (urban) \\
\hline
\end{tabular}


Class A sites - The proportion of each of the 14 land cover types in a $9 \times 9$ patch of $1-\mathrm{km}$ pixels around each point is provided, as a measure of land cover homogeneity and the "representativeness" of the site. The associated land cover value for the centered1-km pixel and the $0.5^{\circ}$ pixel from the Hansen et al. (in press) land cover data set is also given.

Class B sites - The associated land cover type value for the original $1-\mathrm{km}$ pixel and the $0.5^{\circ}$ pixel from the Hansen et al. (in press) land cover data set is provided. The number of unique land cover types (with a possible maximum of 14) in a $5 \times 5$ neighborhood patch of $0.5^{\circ}$ cells around each site provides an indication of the homogeneity in land cover at the site.

Class C cells - The $0.5^{\circ}$ land cover designation for Class C cells was developed from Hansen et al. (in press) 1-km land cover product derived from satellite data. The accuracy of classification of land cover at $0.5^{\circ}$ cell depends heavily on homogeneity in nature. This $0.5^{\circ}$ cell landcover map has been available for more than a year or so without any change. Some inconsistencies between field observations and classified land cover types at $0.5^{\circ}$ cell size are caused by differences in scales, methods, and other factors that are out of our control.

\subsection{CLIMATE}

The climate data for Class A and B sites were extracted by Wolfgang Cramer and Stephen Sitch, PIK. They used a combination of the long-term monthly averages (1931-1960) from the PIK database (Leemans and Cramer 1991) and a 95-year monthly time series (1900-1995) based on the University of East Anglia climate database (New et al. 2000b; see also New et al. 1999 and 2000a):

http://www.daac.ornl.gov/daacpages/climate_collections.html

The 95-year series was generated for the Class A sites only, while the 30-year means were generated for all of the Class A and B sites. Latitude, longitude, and elevation were used for interpolation; therefore, estimated climate depends on the accuracy of the site location. The approximate minimum and maximum temperatures were calculated from the average temperature by subtracting or adding one-half the diurnal temperature range. The annual mean was calculated as the mean of the 12 monthly means, while the annual minimum was calculated as the minimum of the 12 monthly minimums (not the mean minimum) and the annual maximum was calculated as the maximum of the 12 monthly maximums. The climate surfaces cover all of the land area north of $60^{\circ} \mathrm{S}$ and the nearby oceans. Some sites on isolated islands and in Antarctica do not have climate data.

For Class C cells, climate variables are calculated by Daolan Zheng based on the data set of New et al. $(1999,2000)$ for the period 1961-1990 and on the long-term monthly averages (1931-1960) from the PIK database (Leemans and Cramer 1991) to keep the consistency with EMDI I climate data. Transient monthly climate for the 1901-1995 were extracted from New et al. (2000b) for the Class C cells, although the diurnal temperature range was only available for the years 19311995 so that minimum and maximum temperatures were limited to those years.

\subsection{SOILS}

Soils data for EMDI sites were extracted by Dick Olson and Keri Johnson, ORNL, from the IGBP Global Soil Data Task CD-ROM (Global Soil Data Task 2000): 
http://www.daac.ornl.gov/DAAC/cd_roms.html\#soil

The prototype data were the same as the final product. From these data sets, we calculated the means of 14 distinct EMDI soil characteristics. Soils data were extracted at a 5-minute resolution for Class A and B sites and at a $0.5^{\circ}$ resolution for Class C cells. The soil parameters extracted are given in Table 7.

Table 7. EMDI soil parameters extracted from the IGBP Soils Database

\begin{tabular}{lll}
\hline \multicolumn{1}{c}{ Name } & \multicolumn{1}{c}{ Units } & \multicolumn{1}{c}{ Label } \\
\hline SAND & $\% \mathrm{w} / \mathrm{w}$ & Sand content in top $30 \mathrm{~cm}$ \\
SILT & $\% \mathrm{w} / \mathrm{w}$ & Silt content in top $30 \mathrm{~cm}$ \\
CLAY & $\% \mathrm{w} / \mathrm{w}$ & Clay content in top $30 \mathrm{~cm}$ \\
WP & Millimeters & Wilting point in top $30 \mathrm{~cm}$, \\
& & WP water potential $(\mathrm{kPa})=-1500$ \\
FC & Millimeters & Field capacity (water holding capacity) in top $30 \mathrm{~cm}$, \\
& & FC water potential $(\mathrm{kPa})=-10$ \\
PAWC & Millimeters & Profile available water capacity in top $30 \mathrm{~cm}$, \\
& & FC water potential $(\mathrm{kPa})=-10$ \\
& & WP water potential $(\mathrm{kPa})=-1500$ \\
SOILN30 & $\mathrm{g} \mathrm{m}^{-2}$ & Soil nitrogen in top $30 \mathrm{~cm}$ \\
SOILN20 & $\mathrm{g} \mathrm{m}^{-2}$ & Soil nitrogen in top $20 \mathrm{~cm}$ \\
SOILN100 & $\mathrm{g} \mathrm{m}^{-2}$ & Soil nitrogen in top $100 \mathrm{~cm}$ \\
SOILC30 & $\mathrm{kg} \mathrm{m}^{-2}$ & Soil carbon in top $30 \mathrm{~cm}$ \\
SOILC20 & $\mathrm{kg} \mathrm{m}^{-2}$ & Soil carbon in top $20 \mathrm{~cm}$ \\
SOILC100 & $\mathrm{kg} \mathrm{m}^{-2}$ & Soil carbon in top $100 \mathrm{~cm}$ \\
PH & & Soil pH (water) in top $30 \mathrm{~cm}$ \\
BD & $\mathrm{g} \mathrm{cm}^{-1}$ & Bulk density of top $30 \mathrm{~cm}$ \\
\hline
\end{tabular}

The background information presented below was extracted from the IGBP Global Soil Data Task CD-ROM (Global Soil Data Task 2000).

The Global Soil Data Task, coordinated by the Data and Information System (DIS) framework activity of the International Geosphere-Biosphere Programme (IGBP), aims to "assemble a reliable and accessible data set on pedosphere properties on a global scale" (Scholes et al. 1995). Its objectives include the production of (a) specific-purpose derived data-sets (e.g., statistical properties of soil water-holding capacity) for major classes of global soils and (b) spatial data on specific soil properties (e.g., water-holding capacity) at various scales appropriate for modelling and inventory purposes (Scholes et al. 1995).

In the first phase of the task, these data are to be derived from (a) the WISE pedondatabase produced by the International Soil Reference and Information Centre (ISRIC) (Batjes 1995) and (b) the FAO-UNESCO Digital Soil Map of the World (DSMW) (FAO 1995). Each pedon-record in the WISE-database is classified in the FAO-UNESCO 1974 legend (FAO 1995). The WISE-database therefore provides soil-profile data that can be directly linked to the DSMW. Hence, it provides a basis for generating statistics on soil properties for major classes of global soils and for 
different areas of the world at various spatial scales. This document describes one approach adopted, and the software developed (a program called SOILDATA), for generating such data.

The following pedotransfer functions are used for deriving secondary pedon-attribute data from the primary pedon records. In all cases, $\rho_{i}$ denotes the bulk density $\left(\mathrm{g} \mathrm{cm}^{-3}\right)$, and $z_{i}$ the thickness (m), of soil-horizon $i$.

a) Soil carbon density $\left(\mathrm{kg} \mathrm{m}^{-2}\right)$, the total mass of organic carbon in a given soildepth interval, is given by

$c=\sum_{i} 10 \rho_{i} c_{i} z_{i}$

where $c_{i}$ is the organic carbon content (\% by weight) of all soil-horizons $i$ in the required soil-depth interval.

b) Total soil-nitrogen content $\left(\mathrm{g} \mathrm{m}^{-2}\right)$ is given by

$$
N=\sum_{i} 10000 \rho_{i} n_{i} z_{i}
$$

where $n_{i}$ is the nitrogen content (\% by weight) of soil-horizon $i$.

c) The soil water-content $(\mathrm{mm})$ at field-capacity $\left(\theta_{\mathrm{FC}}\right)$ and wilting-point $\left(\theta_{\mathrm{WP}}\right)$ are derived using the van Genuchten (1980) equation

$\theta=\theta_{r}+\left(\theta_{s}-\theta_{r}\right) /\left(1+|\alpha \psi|^{n}\right)^{m}$

where $\theta$ is the volumetric water content $\left(\mathrm{m}^{3} \mathrm{~m}^{-3}\right), \theta_{\mathrm{s}}$ is the saturated water content $\left(\mathrm{m}^{3}\right.$ $\left.\mathrm{m}^{-3}\right), \theta_{\mathrm{r}}$ is the residual water content $\left(\mathrm{m}^{3} \mathrm{~m}^{-3}\right), \varphi$ is the matrix water potential $(\mathrm{kPa})$ and $\alpha, n$ and $m$ are curve parameters, with $m=1-1 / n$. By default, $\varphi=-10 \mathrm{kPa}$ for $\theta_{\mathrm{FC}}$, and $\varphi=-1500 \mathrm{kPa}$ for $\theta_{\mathrm{WP}}$ (IGBP-DIS 1998), although $\varphi$ can be set in each case as required.

d) The profile available water content (PAWC) is given by

$$
P A W C=\theta_{F C}-\theta_{W P}
$$

In addition to the soils data from the IGBP Soils Database for Class $C$ cells, the percentage of sand, silt, and clay was compiled from the Zobler (1986) data set. [Available as: Post, W. M. 2000. Global Soil Types by 0.5-Degree Grid (modified Zobler). Available online at http://www.daac.ornl.gov / from the ORNL Distributed Active Archive Center, Oak Ridge National Laboratory, Oak Ridge, Tennessee.] Quality assessment of soils confirmed that the sum of the soil particle-size fractions (sand, silt, and clay) was equal to $100 \%$.

\subsection{NDVI}

NDVI data was extracted from the Pathfinder AVHRR [Advanced Very High Resolution Radiemeter] Land (PAL) data set (James and Kalluri 1994) by Rob Braswell, University of New Hampshire. These data are available as 10-day composites for August 1981 to August 1994 in global 8-km Goode's Homolosine (equal area) projection.

The cloud mask that accompanies the PAL 10-day composites was applied, using the most conservative approach of masking all pixels that are flagged as "cloudy" or "mixed." The NDVI 
data were recomposited to one month in order to minimize the effects of variable atmospheric conditions and viewing geometry.

To extract the time series, the EMDI latitude-longitude coordinates were converted into Goode's $\mathrm{X}-\mathrm{Y}$ coordinates, then all the 8-km NDVI pixels within a $25-\mathrm{km}$ radius of the EMDI point were averaged (excluding cloudy and quality control (QC)-flagged pixels). Ice- and snow-covered land is generally identified as cloudy by the cloud retrieval algorithm so only vegetated/potentially vegetated pixels are included in the average. Persistent clouds and snow cover will often result in having no pixels associated with the site for some number of months. These missing data are assigned a value of -999 .

To represent site patterns for modeling, 3-year monthly averages were calculated for Class A and B sites based on 1986, 1987, and 1990. These are the only years that do not contain an instrument changeover or a major pulse of volcanic aerosols. Coincidentally, the 3 years are fairly anomalous with respect to global climate: 1986 and 1987 were ENSO years and 1990 was the warmest year in the AVHRR record.

A 13-year average NDVI was provided for EMDI II Class C cells by Daolan Zheng based on an analysis of the relationships between 3-year and 13-year NDVI values. The results of that analysis are briefly summarized in Appendix B.

\subsection{ATMOSPHERIC $\mathrm{CO}_{2}$}

Estimates of global annual atmospheric $\mathrm{CO}_{2}$ levels from 1832 to 1997 were provided by the Carbon Dioxide Information and Analysis Center (CDIAC) at ORNL (see $\mathrm{http}$ //cdiac.esd.ornl.gov/cdiac/). The series is a combination of data from the smoothed Law Dome ice core records for years through 1978 (Etheridge et al. 1998) and Mauna Loa measurements for years from 1979 to present, from the Keeling and Whorf (2001) $\mathrm{CO}_{2}$ data set. The same $\mathrm{CO}_{2}$ data were provided for Class $\mathrm{A}$ and $\mathrm{B}$ sites and Class $\mathrm{C}$ cells.

\section{NPP MEASUREMENT DATA}

The measurements of NPP were categorized as either Class A, representing intensively studied or well-documented study sites; Class B, representing more numerous "extensive" sites with less documentation and site-specific information available, or Class $\mathrm{C}$, representing regional collections of $0.5^{\circ}$ latitude-longitude grid cells (Fig. 1).

Class A sites - Class A data represent intensively studied or well-documented study sites (e.g., with site-specific climate, soils information, etc.) and have complete NPP measurements and good documentation. Sites include grassland, tropical forest, temperate forest, and boreal forest biomes. Although most of these NPP estimates have been published in the literature, complete information on the methods and site conditions was often not readily available.

Class B sites - Class B data represent more numerous "extensive" sites with less documentation and site-specific information available and include study sites from many biomes compiled from existing collections of data. Although most of these NPP estimates have been published in the literature, complete information on the methods and site conditions was often not readily 
available. The information on Class B sites is generally "as provided" and is not fully standardized or consistent between sites.

Class $\mathbf{C}$ cells - Class $\mathrm{C}$ data represent regional collections of $0.5^{\circ}$ latitude-longitude grid cells sites from many biomes compiled from collections of data that have NPP estimates. Most field data for NPP are for relatively small field sites that are effectively points when considered at the $0.5 \times 0.5$ degree scale commonly used in global biogeochemical models. Thus, direct comparison between field data and coarse resolution model outputs has a high degree of uncertainty. Potential problems in data-model intercomparisons and issues that must be considered during the aggregation of field-scale data to coarser spatial resolutions are discussed by Zheng et al. (2001a, in review). Additional details on developing the Class $\mathrm{C}$ data set are provided in Appendix B.

\subsection{CLASS A NPP POINT DATA}

The NPP data compiled by the NCEAS Working Groups and other GPPDI activities were used to create the Class A data the EMDI activity. Under the auspices of GPPDI, a series of three Working Group meetings were held at NCEAS to take extensive but incomplete data sets and make them usable for analyses and models by estimating total NPP in a consistent manner, for points and for grid cells (i.e., $0.5^{\circ}$ ). In addition, NPP projects at the Oak Ridge National Laboratory (ORNL PI R. J. Olson) and the University of Maryland (UMD PI S. D. Prince) were funded by the NASA Terrestrial Ecosystems Program to compile much of NPP data described in this section.

We compiled 162 NPP estimates for 150 unique Class A sites that represent grassland, tropical forest, temperate forest and boreal forest sites that have complete NPP measurements (aboveground and below ground components) and relatively complete documentation. NPP data for 140 of these sites were the product of the extensive review as part of the NCEAS NPP working groups described in Sect. 1 including 30 tropical forests (Clark et al. 2001); 69 boreal forests (Gower et al. in press); and 41 grasslands (Gill et al. in press). These sites had NPP estimates for aboveground and below ground components either as provided by the primary data source or as estimated in the respective synthesis papers.

Data for the remaining 10 sites came from a variety of site-specific sources that reported NPP for aboveground and below ground components. These data were reviewed and compiled by Jonathan Scurlock and Dick Olson. Sources included 5 grasslands (Pandey and Singh 1997; Sims and Singh 1978; Singh and Yadava 1997; Uresk, Sims, and Dodd 1996); 3 tropical forests (Clark 1999, DeAngelis et al. 1997, Nye and Greenland 1998); 2 boreal forests (Comear and Kimmins 1999, Linder and Agren 1998); and temperate forests (Waring et al. 1999; P.J. Hanson pers. comm. 1999). For further information and site-specific data, refer to the ORNL DAAC NPP database:

http://www.daac.ornl.gov/NPP/npp_home.html

The information is generally "as provided"; however, the goal of the NCEAS and ORNL review processes were to select NPP estimates that were based on comparable methods and expressed in common units of measure.

Of the original 150 unique candidate sites, 69 sites were eventually eliminated: 
- 13 sites lacking driver data because of limited spatial resolution in global coverages (e.g., sites near coastal areas, islands, etc.)

- 22 sites lacking below ground NPP (BNPP)

- 28 sites for which we were unable to acquire NPP estimates within the EMDI schedule

- 6 sites were eliminated in the outlier analysis (see Sect. 5).

Most of the NPP estimates were provided in units of dry biomass (organic matter). We converted these to carbon units (e.g., $\mathrm{gC} / \mathrm{m}^{2} / \mathrm{y}$ ) using a mass fraction of 0.5 for woody components and 0.45 for grass and foliage components (Raich et al 1991, Scurlock and Hall 1998). If we were unable to determine whether the biomass was predominantly wood or foliage, we used a ratio of $0.475 \mathrm{~g}$ $\mathrm{C}$ per $1 \mathrm{~g}$ biomass.

Two files were provided, containing all of the162 individual measurements (NPP_meas) and the 81 site means (NPP_mean) of those unique sites passing the outlier analysis tests. These form the Class A GPPDI and EMDI data sets, respectively.

\subsection{CLASS B NPP POINT DATA}

Class B sites represent grassland, tropical forest, temperate forest, boreal forest tundra, savanna, crops, and plantations sites that have at a minimum aboveground net primary productivity (ANPP) measurements (about 20\% have both ANPP and BNPP), a site location, and documentation (e.g., a literature citation). Most of the Class B data (1324 NPP estimates) represent existing multi-biome collections of data available from the ORNL DAAC (http://daac.ornl.gov/NPP/npp_home.html) (DeAngelis et al. 1997; Esser et al. 1998; Hall 1997; Kicklighter 1999; Krankina 1999; Ni et al. 2001, Waring et al. 1999). An additional 130 NPP estimates were assembled from the ORNL NPP collection of individual sites and 909 NPP estimates were acquired from Tom Gower (see Sect. 3.2.3). Although most of these NPP estimates have been published in the literature, complete information on the methods and site conditions was often not readily available. The information on Class B sites is generally "as provided" and is not fully standardized or consistent between sites.

The following describes the Class B data that Jonathan Scurlock and Dick Olson extracted from the ORNL DAAC NPP data collections, compiled as part of the NPP project at ORNL with funds from the NASA Terrestrial Ecosystems Program.

\subsubsection{ORNL DAAC Data Sets}

Chinese forests NPP data set - Data on biomass and NPP of major Chinese forest types were compiled based on the inventories of the Forestry Ministry of China between 1989 and 1993. Additional data were obtained from published forest reports, as well as from more than 60 Chinese journals and some unpublished literature up to 1994 (Luo 1996; Ni et al. 2001). The data cover six major forest biomes, including 690 study sites from 17 forest types in China, ranging across a substantial geographical area, from sub-boreal Larix forests in northeast China (Heilongjiang Province; approx. $53^{\circ} \mathrm{N}, 122^{\circ} \mathrm{E}$ ) and northwest China (Xinjiang Province; approx. $48^{\circ} \mathrm{N}, 86^{\circ} \mathrm{E}$ ) to tropical rain forests in southern China (Yunnan Province; approx. $22^{\circ} \mathrm{N}, 100^{\circ} \mathrm{E}$ ) and Hainan Island $\left(18^{\circ} \mathrm{N}, 108^{\circ} \mathrm{E}\right)$. Latitude, longitude, elevation, leaf area index, total biomass, and total NPP (the sum of aboveground and below ground components) are given for each site. 
Chinese forests, which cover about half of the total area of China, contain perhaps the widest range of types in the world, ranging from boreal forest and mixed coniferous broad-leaved forest in the north, temperate deciduous broad-leaved forest and coniferous forest in the central region, to subtropical evergreen broad-leaved forest, warm temperate coniferous forest, tropical rain forest, and seasonal forest in the south. The elevation of the forest study sites ranges from 10 to $4240 \mathrm{~m}$ (mean $=1385 \mathrm{~m}$ ), and stand age from 3 to 350 years (mean $=66$ years). Total biomass ranges from 3114 to $156985 \mathrm{~g} / \mathrm{m}^{2}$ (mean $=18500 \mathrm{~g} / \mathrm{m}^{2}$ ), total NPP (aboveground plus below ground) from 241 to $4027 \mathrm{~g} / \mathrm{m}^{2} / \mathrm{yr}\left(\right.$ mean $\left.=1440 \mathrm{~g} / \mathrm{m}^{2}\right)$, and leaf area index (projected) from 0.17 to 41.78 (mean $=8.9$ ). Caution is advised in using these data because conversions were universally applied that may not be consistent with the methodologies used to collect the data.

IBP woodlands data set - The IBP (International Biological Programme) Woodlands Data Set (DeAngelis et al. 1981) consists of contributions from 117 international forest research sites, all but a few associated with projects committed to the IBP. The data were collected in the 1960s and early 1970s and compiled into a single data set at the ORNL to facilitate comparisons involving the diverse woodland ecosystems. Representatives of almost every kind of forest ecosystem are present in the data set. A hierarchical scheme was used to assign a forest type to each site based on the climate, life-form, and status features of the site. Included are sites of the following types, with the number of each type in parentheses: tropical (26), Mediterranean (3), temperate (55), and boreal (33). With respect to life form, 72 sites were dominated by broad-leaved species and 45 were needle-leaved. There were 65 deciduous stands and 52 evergreen. Finally, 89 sites consisted of natural forest and 28 were managed.

Osnabrück NPP data set - An extensive compilation of field data on NPP of natural and agricultural ecosystems worldwide was synthesized in the 1970s and early 1980s by Professor H. Lieth, Dr. G. Esser, and others (Esser et al. 1997). Much of this work was carried out at the University of Osnabrück, Germany. More than 700 single-point estimates of NPP or biomass were extracted from the scientific literature, each with a geographical reference (latitude/longitude). The literature cited dates from 1869 to 1982, with the majority of references from the 1960s and 1970s. In the early 1970s, a subset of these NPP data was used by Lieth, Esser, and co-workers to develop and test a series of statistical models of NPP as a function of mean annual temperature and precipitation. The later versions of these models included modifications for soil, seasonality, agriculture, and other human influences ["Osnabrück Biosphere Model" (Esser 1992), "High Resolution Biosphere Model" (Esser and Lautenschlager 1994), etc.)]. Most of the 720 unique NPP records (632 or 88\%) have been matched to a bibliography of 356 references from the literature.

About two-thirds of the 720 records have aboveground NPP estimates that range between 1 and $8530 \mathrm{~g} / \mathrm{m}^{2} / \mathrm{yr}$ (dry matter) or $2923 \mathrm{~g} / \mathrm{m}^{2} / \mathrm{yr}$, excluding outliers, wetlands, and crops/pastures and other likely managed systems. Total NPP, for which more than half of the sites have estimates, ranges from 3 to $9320 \mathrm{~g} / \mathrm{m}^{2} / \mathrm{yr}$ (dry matter) or $3580 \mathrm{~g} / \mathrm{m}^{2} / \mathrm{yr}$, excluding doubtful values, wetlands, and crops/pastures and other likely managed systems. Each record includes a site identifier, latitude, longitude, author, country, NPP estimates, vegetation type, and other variables. The vegetation-type field begins with a generalized biome type (including tundra, forest, Mediterranean, savanna, grassland, desert, wetland, and a number of managed vegetation types) and is followed by more specific vegetation terminology derived from the original data (Esser et al. 1997).

A single NPP value (NPP_C) is included for each site that represents the sum of ANPP and BNPP components, expressed in grams of carbon per square meter per year $\left(\mathrm{g} \mathrm{C}^{-} \mathrm{m}^{2} / \mathrm{yr}\right)$. Where 
BNPP was not reported, it was assumed to be equal to ANPP. A ratio of 0.475 was used to convert dry biomass weight to carbon content.

OTTER NPP data set - The Oregon Transect Ecosystem Research Project (OTTER) was conducted to develop a strategy to extrapolate point measurements and estimates of ecosystem structure and function across large geographic regions that varied in climate and vegetation. The OTTER NPP Data Set (Runyon et al. 1994), described here, contains only the estimates of NPP and associated measurements from the OTTER transect, made during the period 1989-1991 (Runyon et al. 1994). The study region was a transect that began near Cascade Head Experimental Forest, north of Lincoln City, Oregon $\left(44.95^{\circ} \mathrm{N} 124.02^{\circ} \mathrm{W}\right)$, and extended approximately $250 \mathrm{~km}$ to Redmond $\left(44.27^{\circ} \mathrm{N} 121.17^{\circ} \mathrm{W}\right)$, located in the high desert interior of Oregon. The transect included six forest ecosystem sites selected from the same forest community types as an earlier study of biomass, leaf area, and NPP (1976-1977) by Dr. H. L. Gholz. Mean annual temperature varied inversely with elevation, from $11.2^{\circ} \mathrm{C}(170 \mathrm{~m})$ to $6.0^{\circ} \mathrm{C}(1460 \mathrm{~m})$. Annual precipitation ranged from $220 \mathrm{~mm}$ at the eastern-most site to $2510 \mathrm{~mm}$ at the coastal sites, but did not vary linearly across the intervening sites.

Scots Pine NPP data set (Siberia) - Data from 14 stands of Scots Pine at two locations in Siberia were compiled by Olga Krankina of Oregon State University, U.S.A., from reports by Gabeev (1990) and Buzykin (1978). These plots represent one of the main dominant tree species in Siberian forests, growing in stands of relatively high density and productivity. Data reported in Gabeev (1990) were gathered from stands studied under the former USSR International Biological Programme in Tomsk Region, Western Siberia (approx. $58^{\circ} \mathrm{N} 83^{\circ} \mathrm{E}$; 54-year mean precipitation $=501.2 \mathrm{~mm}$ ). Aboveground measurements were obtained using standard allometric forestry methods, and below ground data were originally reported in considerable detail by size, class, and depth. Data reported by Buzykin (1978) are from a study of carbon and nutrient cycling in the forests of the Angara River basin, Irkutsk Region, near Lake Baikal (approx. $53^{\circ} \mathrm{N} 103^{\circ}$ E). Here, Scots Pine (Pinus sylvestris) is the dominant tree species on about $26 \%$ of the forested area. Trees were measured by standard allometric methods on 0.3 to 0.4 -hectare plots and understory was determined from twenty 0.25 -hectare plots at each site for three successive years. Data on litter fall are mean values from 1968 to 1974 and were reported separately for needles, bark, branches, cones, and other litter. Below ground biomass was determined by excavation of entire root systems, and root turnover was estimated for different size classes.

Superior National Forest - NPP of a boreal forest was determined at 31 spruce and 30 aspen forest stands in the Superior National Forest near Ely, Minnesota, U.S.A., in 1983 and 1984 by the NASA (Hall et al. 1992). The purpose of the experiment was to investigate the ability of remote sensing to provide estimates of biophysical properties of ecosystems, such as leaf area index (LAI), biomass, and NPP. These ground-based estimates of aboveground biomass and NPP are available; more ground measurements plus the satellite, aircraft, and helicopter observations for the study site are also available. The study area covered a $50 \times 50 \mathrm{~km}$ area centered at approximately $48^{\circ} \mathrm{N}$ latitude and $92^{\circ} \mathrm{W}$ longitude in northeastern Minnesota at the southern edge of the North American boreal forest. Sites for biophysical measurements were chosen to be pure spruce or aspen stands. Allometric equations were used to find the height and radial increment as a function of crown height and diameter at breast height.

Terrestrial Ecosystem Model (TEM) NPP data set - TEM is a process-based model developed by staff at the Ecosystems Center, Marine Biological Laboratory, Woods Hole, Massachusetts, U.S.A. (McGuire et al. 1992). Data on pool sizes and fluxes of carbon and nitrogen from 16 field study sites in a wide range of biomes from tundra to tropical forest, but excluding wetlands, were 
used to calibrate the model. Data were compiled from the appendix to McGuire et al. (1992). Mean annual values of carbon in vegetation, nitrogen in vegetation, carbon in soil, nitrogen in soil, and inorganic nitrogen in soil, are in $\mathrm{g} / \mathrm{m}^{2}$ of either carbon or nitrogen. Values of gross primary productivity, NPP, nitrogen uptake by vegetation, saturation response of NPP to nitrogen fertilization, and the annual amount of nitrogen mobilized for production via recycling are in $\mathrm{g} / \mathrm{m}^{2} / \mathrm{yr}$.

\subsubsection{Combined Class B Data Sets}

A set of 1690 candidate locations (latitude/longitude) were identified by combining the data from the sources just listed, often with multiple NPP estimates available for each location. Certain locations, such as the carbon dioxide $\left(\mathrm{CO}_{2}\right)$ flux tower sites, Earth Observing System (EOS) validation sites, and the International Long-Term Ecological Research (ILTER) Global Network of Environment and Technology (GNET) sites, were included with the expectation of having NPP data later in 1999, but these were not available at the time of the EMDI workshop (December 1999). Some sites were "flagged" to indicate that the NPP estimate was thought not to be representative of the natural conditions at that location (e.g., fertilizer treatments).

The final number of Class B sites used in the EMDI workshop was less than 1690 after elimination of sites for a series of reasons. Some of the reasons include

- sites lacking either latitude or longitude,

- crop sites that were fertilized or irrigated,

- $\quad$ sites lacking driver data because of limited spatial resolution in global coverages (e.g., sites near coastal areas, islands, etc.),

- $\quad$ sites for which we were unable to acquire NPP estimates within the EMDI schedule, and

- $\quad$ sites were eliminated in the outlier analysis (see Sect. 5).

\subsubsection{Additional Class B Data Sets}

In October 1999, Tom Gower, University of Wisconsin, provided a supplementary NPP data set containing 2193 records, including many records that he obtained from ORNL DAAC NPP sources. He extracted additional NPP data from Cannell (1982) and a variety of more recent sources. We performed the following processing to select records from Gower's data set that were not already in the Class B set which were then combined with the existing set of Class B records. First we eliminated sites that had the same latitude/longitude as already in the Class B set of 1900 records as of October 8, 1999. We also removed sites that were not included in the set of 1690 Class B sites with driver data. This eliminated most of the duplicate ODS, IBP, TEM, SNF, OTTER, and other sites in Gower's file, resulting in about 1000 new unique records. We favored the NPP data from the ORNL compilation when similar data were in the Gower compilation because we had already removed sites with known fertilizer or irrigation treatments and we had also dropped data for crops when only the ANPP values were recorded. We identified and dropped records in Gower's file that were missing latitude or longitude, had no NPP, or had NPP exceeding $4000 \mathrm{gC} / \mathrm{m}^{2} / \mathrm{y}$ (and were almost certainly fertilized). Additional duplicate records were dropped that had identical NPP values.

The final Gower subset included 909 records representing 273 new sites. Gower's NPP values were multiplied by 47.5 to convert from $\mathrm{t} / \mathrm{ha} / \mathrm{yr}$ (organic matter) to $\mathrm{gC} / \mathrm{m}^{2} / \mathrm{y}$. It was noted that the ANPP estimates in the Gower set was about $40 \%$ higher than in the ORNL set. The resulting 
Class B data set contained 2363 NPP measurements for 1271 unique sites, $75 \%$ of the 1690 sites. We then calculated the $\mathrm{min} / \mathrm{mean} / \mathrm{max}$ for the 1271 unique sites to distribute to the modelers.

\subsubsection{Estimating Total NPP}

For those sites lacking a value for total net primary productivity (TNPP), we estimated TNPP (NPP_EST) from ANPP or BNPP by calculated biome-specific ratios from sites that had both ANPP and BNPP measurements. We calculated these ratios based on the biome classification reviewed at the EMDI I workshop and using data with outliers excluded (see Sect. 5). The rations of ANPP to BNPP differ by biome (Fig. 3). Based on our analysis, we used a ratio of 0.5 BNPP:TNPP for grasslands, deserts, and tundra and a ratio of 0.22 BNPP:TNPP for forests (see Appendix C).

Two files were provided for the Class B sites, one having the 2363 individual measurements (NPP_meas) and one having the mean NPP for each of the 933 unique sites (NPP_mean) of those measurements passing the outlier analysis.

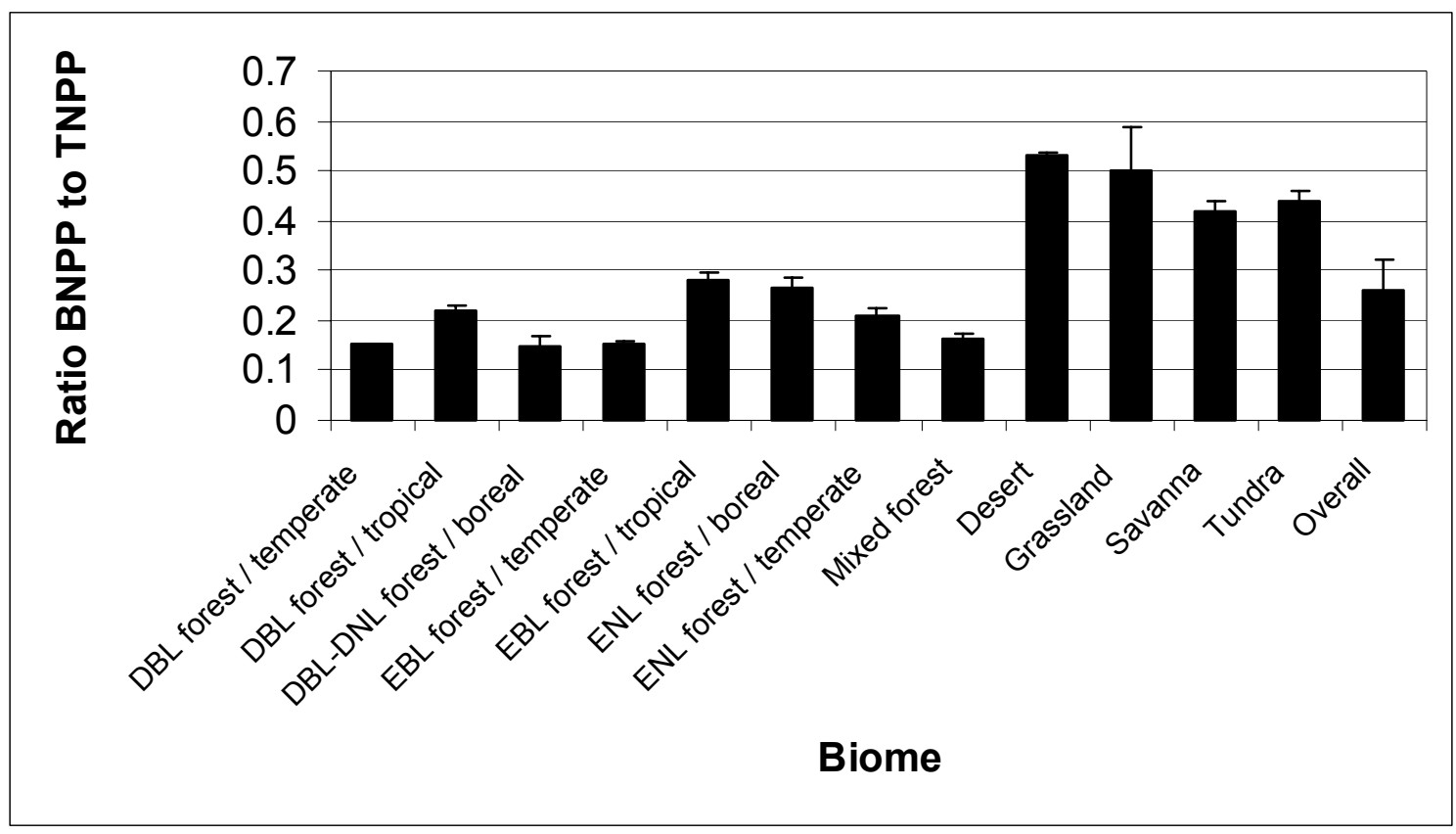

Fig. 3. Mean ratio and standard error of below ground (BNPP) net primary productivity to total NPP for aggregated biomes.

\subsection{CLASS C NPP GRID CELL DATA}

NPP and driver data for EMDI II Class C cells were compiled by Daolan Zheng and Steve Prince, Geography Department at UMD (version dated October 4, 2000). Drivers includes elevation, biome, monthly climate (mean, min, and max temperature and total precipitation), NDVI, and soil texture (fraction sand, silt, and clay). The specific contents are described in Appendix B along with notes describing the processing performed by UMD.

The EMDI II Class C grid cell-based data set was derived from the 5164 NPP estimates for $0.5^{\circ}$ grid cells in the GPPDI database. The GPPDI database contains 3555 estimates ( $79 \%$ in the 
U.S.A.) that were developed from 14 studies representing NPP in croplands, sparse vegetation, shrublands, grasslands, and forests worldwide (Zheng et al. 2001a) plus an additional 1609 cells added after the Zheng et al. (2001b) paper was submitted. The data set consists of new data for 2334 grid cells from Australia, China, South America, Senegal, Finland, and Sweden combined with the 2830 cells from Class C data for the United States compiled for EMDI I (Table 8). Total NPP ranged from $3 \mathrm{gC} / \mathrm{m}^{2} / \mathrm{y}$ for sparse vegetation to $1235 \mathrm{gC} / \mathrm{m}^{2} / \mathrm{y}$ in forest, while aboveground NPP ranged from 3 to $890 \mathrm{gC} / \mathrm{m}^{2} / \mathrm{y}$ (Zheng et al. 2001a).

During the analysis of the set of 3555 Class $C$ grid cells, it was discovered that there were 17 grid cells located along the transition between grassland and forest in the U.S.A. with multiple biome assignments and 1 cell in Australia with no driver data. Therefore, a set of 3837 unique cells was available for model-data intercomparison.

Table 8. Sources and information about Class $C$ grid cell NPP

\begin{tabular}{lllc}
\hline $\begin{array}{c}\text { Cell ID } \\
\text { range }\end{array}$ & \multicolumn{1}{c}{ Sources } & \multicolumn{1}{c}{ Location } & $\begin{array}{c}\text { Number of } \\
\text { cells }\end{array}$ \\
\hline 1000s: & Larry Tieszen & Great Plains, U.S.A. & 922 \\
2000s: & M. Hansen & Yellowstone, U.S.A. & 3 \\
4000s: & Ken Day & Australia & 1 \\
5000s: & Scott Goetz & Minnesota, U.S.A. & 2 \\
6000s: & Jennifer Jenkins & Mid-Atlantic and Maine, U.S.A. & 245 \\
7000s: & Olga Krankina & Russia, SE and NE U.S.A. & 8 \\
8000s: & Osvaldo Sala & Great Plains, U.S.A. & 100 \\
9000s: & Steve Prince & Mid-West, U.S.A. & 220 \\
10000s: & David Turner & Pacific Northwest, U.S.A. & 1 \\
11000s: & Robin Kelly, Bill Parton & Great Plains, U.S.A. & 1262 \\
13000s: & Sandra Brown & Eastern U.S.A. & 62 \\
14000s- & Damien Barrett & Australia & 615 \\
17000s: & & & \\
18000s: & Daolan Zheng & Finland and Sweden & 82 \\
19000s: & O. Diallo & Senegal & 32 \\
20000s- & Jim Raich & South America & 1510 \\
21000s: & & & 99 \\
22000s: & H. Jiang & China & 5164 \\
Total & & & \\
\hline
\end{tabular}

\subsubsection{Scaling Methods}

Many of the studies provided estimates for ANPP but not TNPP (see Table 9). Where possible we have calculated missing components to provide estimates of TNPP as described in the notes in Sect. 3.2.4. In addition, a variety of methods were used to derive the $0.5^{\circ}$ grid-cell estimates. Table 9 summarizes methods used by each study. Principal methods used for estimation of $0.5^{\circ}$ cell NPP data include

- stratification of grid cells and area weighting of field NPP observations in each stratum;

- aggregation of finer scale (plot or stand level) spatial inventory data;

- local modeling of NPP using key environmental variables, for which maps are available; and

- direct correlation of ground measurements with remotely sensed vegetation indices. 
Table 9. Summary of the availabilities of ANPP and TNPP in the 16 original studies $(y=y e s, n=n o$, and $e=$ estimated $)$ along with NPP estimation and scaling methods

\begin{tabular}{|c|c|c|c|c|}
\hline $\begin{array}{l}\text { Cell ID } \\
\text { range }\end{array}$ & ANPP & TNPP & NPP estimation method & $0.5^{\circ}$ Cell scaling method \\
\hline 1000s: & $\mathrm{y}$ & $\mathrm{y}$ & Rangeland inventory & $\begin{array}{l}\text { Aggregated to } 0.5^{\circ} \text { cells based on } 1-\mathrm{km} \\
\text { cells derived from soil maps }\end{array}$ \\
\hline 2000s: & $\mathrm{y}$ & $\mathrm{n}$ & $\begin{array}{l}\text { Measurements of DBH } \\
\text { increment ( } 540 \text { plots) within } \\
\text { uniform stands }\end{array}$ & $\begin{array}{l}\text { Multiple regression - cover type, } \\
\text { topography, soils for each stand type }\end{array}$ \\
\hline 4000s: & $\mathrm{y}$ & $\mathrm{n}$ & $\begin{array}{l}\text { Measurements of grassland } \\
\text { biomass increment }\end{array}$ & $\begin{array}{l}\text { GRASP pasture production model } \\
\text { based on rainfall }\end{array}$ \\
\hline 5000s: & $\mathrm{y}$ & $\mathrm{y}$ & Forest inventory (2711 plots) & $\begin{array}{l}\text { mean of plots for given forest type, then } \\
\text { areal weighted }\end{array}$ \\
\hline 6000s: & $\mathrm{y}$ & $\mathrm{y}$ & Forest inventory (2640 plots) & Weighted mean of plots in cells \\
\hline 7000s: & $\mathrm{y}$ & $\mathrm{y}$ & Forest inventory & $\begin{array}{l}\text { mean of stands for different type (in } \\
\text { Russia) or means of counties (in } \\
\text { U.S.A.), areal weighted or resampled }\end{array}$ \\
\hline 8000s: & $\mathrm{y}$ & e & Rangeland inventory & $\begin{array}{l}\text { Means by Major Land Resource Areas } \\
\text { (MLRA) associated with } 0.5^{\circ} \text { cells } \\
\text { within MLRAs }\end{array}$ \\
\hline 9000s: & $\mathrm{n}$ & $\mathrm{y}$ & $\begin{array}{l}\text { Crop inventory and growth } \\
\text { model }\end{array}$ & Means by county extrapolated to $0.5^{\circ}$ \\
\hline 10000s: & $\mathrm{n}$ & $\mathrm{y}$ & $\begin{array}{l}\text { Literature giving estimates by } \\
\text { stand age }\end{array}$ & $\begin{array}{l}\text { Association of NPP with high resolution } \\
\text { map of stand age }\end{array}$ \\
\hline 11000s: & $\mathrm{y}$ & $\mathrm{y}$ & Rangeland inventory & $\begin{array}{l}\text { Empirical relationship with } \\
\text { precipitation used with }\end{array}$ \\
\hline 13000s: & $\mathrm{e}$ & e & Forest inventory by county & Association of $0.5^{\circ}$ cells within counties \\
\hline $\begin{array}{l}\text { 14000s- } \\
17000 \mathrm{~s}:\end{array}$ & $\mathrm{y}$ & $\mathrm{y}$ & Literature & $\begin{array}{l}\text { Least-squares statistical model based on } \\
\text { climate, soils, and vegetation }\end{array}$ \\
\hline 18000s: & $\mathrm{y}$ & $\mathrm{y}$ & $\begin{array}{l}5 \text {-year set of forest } \\
\text { measurements ( } 660 \text { plots }) \text { with } \\
\text { allometric equations }\end{array}$ & $\begin{array}{l}\text { Calibrated TM/AVHRR imagery with } \\
\text { field data, aggregate to } 0.5^{\circ} \text { cells }\end{array}$ \\
\hline 19000s: & $\mathrm{y}$ & $\mathrm{n}$ & $\begin{array}{l}\text { 11-year set of measurements for } \\
\text { major cover types }\end{array}$ & $\begin{array}{l}\text { Calibrated AVHRR Model with field } \\
\text { data }\end{array}$ \\
\hline $\begin{array}{l}20000 \mathrm{~s}- \\
21000 \mathrm{~s}:\end{array}$ & $\mathrm{n}$ & $\mathrm{y}$ & $\begin{array}{l}\text { Calibrated model based on } \\
\text { literature values }\end{array}$ & TEM model simulations for $0.5^{\circ}$ cells \\
\hline 22000s: & $\mathrm{n}$ & $\mathrm{y}$ & Forest inventory (>1000 plots) & $\begin{array}{l}\text { Mean NPP for } 33 \text { forest classes, } \\
\text { extrapolated to region at } 6-\mathrm{km} \text {, } \\
\text { aggregated to } 0.5^{\circ} \text { cells }\end{array}$ \\
\hline
\end{tabular}




\subsubsection{Individual Data Set Descriptions}

Several of the data compilers (Goetz, Jenkins, Krankina, and Brown) used the USDA Forest Service Forest Inventory and Analysis (FIA) data and another group of the data compilers (Sala, Tieszen, and Kelley) used the USDA Soil Conservation Service rangeland productivity inventory. We present a general overview of the FIA and Rangeland data here, while the subsections below provide details about how each scientist extracted NPP data from these or other databases. Table 8 provides a summary of the number of cells and geographic location, cross-referenced by Cell IDs.

USDA Forest Inventory and Analysis Data (FIA) - The USDA Forest Service has conducted periodical and extensive surveys of nation's forested land since 1928 (Birdsey and Schreuder 1992). While an annual sampling scheme is currently being implemented nationwide, recent inventories have typically been conducted every 10 to 13 years in the Pacific northwestern states (Zheng and Alig 1999), 5 to 7 years in the southeastern states, and 10 to 15 years in the northeastern states (Jenkins et al. 2001). Plot- and tree-level inventory data can be obtained from the Eastwide Forest Inventory Database (Hansen et al. 1992) established and maintained by USDA Forest Service FIA units in the Northeastern, North Central, Southern, and Southeastern Research Stations.

For the eastern United States, inventory samples are collected separately for each state and follow a two-phase scheme. In phase 1, remotely sensed data (such as airphotos or satellite imagery) are interpreted and classified on land cover (cropland, urban, pasture, forest, etc.). For forested land, more detailed classes may be identified based on additional variables, such as species group, timber volume, and stem density; the criteria used to define categories for forested lands differ from state to state. In phase 2, ground plots are stratified by photoclass and established in random locations or grid points across the landscape both to correct any errors made during photo interpretation and to gather information that cannot be obtained from the remotely sensed data.

Each of the plots chosen for sampling during phase 2 is visited by a specially trained field crew. The inventory sample for forested plots consists of a set of plot-level measurements (e.g., geographic coordinates, basal area, total timber volume, forest type, and land use classification, and a set of tree-level measurements (e.g., species, diameter at breast height, and sawlog volume). As state inventories are completed, county-level summaries are compiled and presented in published reports at the state level.

USDA Rangeland Productivity Inventory - The USDA Rangeland Productivity Inventory includes productivity estimates for 9498 sites throughout the Central Grassland region of the United States (Joyce et al. 1986). For each site, the database contains estimates of primary production for favorable, unfavorable, and average years, as well as a description of the soil profile that includes texture of the A horizon. Primary production included the aboveground parts of all plants (except mosses and lichens) produced during a single growth year, regardless of accessibility to grazing animals.

Cell ID $=1000$ s (Tieszen et al. 1997) - In the Great Plains region, NPP was calculated using a combination of methods. The State Soil Geographic (STATSGO) database was used to estimate mean potential ANPP for map units related to soil surveys at each site (Tieszen et al. 1997).

These, or the more detailed county soil and range survey data, were mapped for each cell and used to display ANPP across the cell. The algorithm derived by Gill et al. (2001) was used to convert from ANPP to total NPP, as follows: 
$\mathrm{NPP}=\mathrm{ANPP}+\mathrm{BNPP}$

$\mathrm{BNPP}=\mathrm{BGbiomass} *$ root live:total matter $*$ root turnover rate

BGbiomass $=($ AGbio*0.79) $)(($ MAT +10$) * 33.3)+1289$

where $\mathrm{AGbio}=$ peak aboveground live biomass interchangeable with ANPP

$\mathrm{MAT}=$ mean annual temperature $\left({ }^{\circ} \mathrm{C}\right)$

root live:total matter $=0.6$

This provided a spatially explicit estimate of potential NPP for average climatic conditions and was aggregated for each $0.5^{\circ}$ cell.

Cell ID $=$ 2000s (Hansen et al. 2000a) - Ninety sample stands were stratified by cover type and elevation, and the results used to predict ANPP across a portion of the Greater Yellowstone Ecosystem $\left(9500 \mathrm{~km}^{2}\right)$. Each stand contained six plots. Tree ANPP was estimated by sampling tree density by species and diameter classes and estimating average annual diameter increment by tree coring (Hansen et al. 2000a). Shrub ANPP was estimated by calculating current biomass from basal area using BIOPAK (Means et al. 1994) and dividing by the assumed average life span of the shrubs. Multiple regressions were used to examine relationships between ANPP and other dependent variables such as cover type, topography, and soil. The best regression model was used to predict ANPP across the study area.

Cell ID $=$ 4000s (Day et al. 1997) - The GRASP model (Day et al. 1997) was calibrated and used to estimate NPP for small cells which were aggregated to estimate NPP for the $0.5^{\circ}$ cells. In Queensland the GRASP model has typically been calibrated from field measurements in small exclosures (approximately $30 \mathrm{~m}$ x $30 \mathrm{~m}$ ). Exclosure of stock during the measurement period minimizes loss of biomass through grazing. Removal of carry-over pasture biomass by mowing or burning at the beginning of the season minimizes losses due to detachment. Thus the measurements of biomass increment more closely represent growth. The calibrated model is validated in time and space by comparing model output to independent data from either the same exclosure, other exclosures, clipping trials, or grazing trials. Grazing trials typically run for a number of years and test a range of stocking rates. Thus they allow the model to be validated under grazed conditions for several years at a small paddock scale (hectares). Provided that processes operating at the grazing trial scale are representative of commercial scale paddocks, the model can be used to calculate pasture growth for broader regions.

ANPP was calculated for a $50 \times 50 \mathrm{~km}^{2}$ region of Astrebla grassland in Queensland for the purpose of validating global ANPP models. The region chosen (between 21.0 to $21.5^{\circ} \mathrm{S}$ and 143.5 to $144.0^{\circ} \mathrm{E}$ ) was spatially uniform but was characterized by marked year-to-year variation in calculated ANPP. Data from similar pastures within 250 x $50 \mathrm{~km}$ from the region were used to calibrate and validate a pasture production model, GRASP. In turn GRASP was used to calculate ANPP for 39 years for $1005 \times 5 \mathrm{~km}^{2}$ cells which were aggregated to $50 \mathrm{x} 50 \mathrm{~km}^{2}$.

ANPP was calculated with the calibrated GRASP model (Day et al. 1997) for a 50 x $50 \mathrm{~km}^{2}$ region surrounding Stamford in northwestern Queensland. Using interpolated rainfall and climate data as input, ANPP was calculated for each of $1005 \times 5 \mathrm{~km}^{2}$ cells that in turn were aggregated to the $50 \times 50 \mathrm{~km}^{2}$ region. Calculated annual ANPP for the 39 -year period in the Stamford region was approximately $2400 \mathrm{~kg} / \mathrm{ha}$, ranging from under $100 \mathrm{~kg} / \mathrm{ha}$ to $3300 \mathrm{~kg} / \mathrm{ha}$ between years.

The GRASP model was calibrated to exclosure measurements (J. O. Carter, unpublished data) at Toorak Field Research Station $\left(21.00^{\circ} \mathrm{S}, 141.80^{\circ} \mathrm{E}\right)$. Although Toorak is approximately $200 \mathrm{~km}$ to the west of the Stamford study area, it is also in the Julia land system and the rainfall regime in 
both locations is almost identical. The calibration data was obtained over two growing seasons in 1986-1987 and 1987-1988. The first year was moderate in terms of rainfall and an irrigation treatment was also applied. The second year was extremely poor in terms of grass production. Thus these data provide a range of seasonal conditions for model calibration.

Cell ID $=$ 5000s (Goetz et al. 2001) - The latest Minnesota FIA field inventory (see FIA description above) was completed between 1988 and 1990 (Hansen et al. 1992) and included 43,957 forested and non-forested plots. Of these, 12,464 plots were located in the northern portion of the state (north of $47.5^{\circ}$ lat.), 4675 of these plots had been measured more than once, and 2897 of the re-measured plots were classified as timberland or forestland. Of these, the 2711 plots with a nonzero value of basal area (BA) were used for this analysis. Plots were assigned to a forest type (white spruce, tamarack, etc.) by the North Central FIA Unit based on the relative BA in each species. The average length of time between inventory measurements was 11.75 years.

Aboveground wood NPP was defined as:

$$
\text { NPP }=\text { biomass }\left(\mathrm{t}_{1}\right)-\text { biomass }\left(\mathrm{t}_{0}\right) /\left(\mathrm{t}_{1}-\mathrm{t}_{0}\right)
$$

Biomass estimates for current conditions $\left(t_{1}\right)$ were found on a tree-by-tree basis using speciesspecific regression equations as described above. Biomass increment on a per-unit-area basis was found by multiplying the tree-level estimates by an expansion factor denoting the number of trees per unit area represented by that stem. Biomass estimates for each stem at the previous inventory $\left(t_{0}\right)$ were also found from dbh. Dbh at the time of the previous inventory was used directly from the Eastwide Forest Inventory Database, or was estimated as described here.

Every tree measured in the current inventory $\left(t_{1}\right)$ falls into one of four categories: alive and measured in the previous inventory ( $d b h$ at $t_{1}$ and $t_{0}$ are both recorded); alive but not measured in the previous inventory (live, cut, and dead trees between 2.54 and $12.7 \mathrm{~cm}$ dbh fall into this category); harvested between $t_{0}$ and $t_{1}$; or died between $t_{0}$ and $t_{1}$. Dbh values from the previous inventory $\left(\mathrm{t}_{0}\right)$ for live trees with two dbh measurements were used directly from the Database. The North Central FIA unit estimates dbh for cut trees at the time of harvest and for dead trees at the time of death, so the current $\left(t_{1}\right)$ and previous $\left(t_{0}\right)$ dbh values for cut and dead trees were used as recorded in the Database unless no dbh value was recorded at the previous inventory. For ongrowth trees (i.e., those that were measured in the current inventory but were too small [less than $12.7 \mathrm{~cm} \mathrm{dbh}$ ] to have a dbh recorded from the previous inventory [Birdsey and Schreuder (1992)], dbh at the time of the previous inventory was estimated using a simple linear algorithm relating dbh increment to tree size class. This algorithm was developed from inventory measurements of 89,938 live re-measured trees in the mid-Atlantic states. If ongrowth trees were cut or dead in the current inventory, they were assumed to have died or been cut halfway through the inventory period.

Total aboveground NPP = aboveground wood NPP + estimated litter fall.

Estimated litter fall was taken from Brown et al. (1999). Those numbers used were $4000 \mathrm{~kg} / \mathrm{ha} / \mathrm{yr}$ for pine, $3200 \mathrm{~kg} / \mathrm{ha} / \mathrm{yr}$ for spruce-fir, and $4500 \mathrm{~kg} / \mathrm{ha} / \mathrm{yr}$ for hardwoods.

$$
\text { Total NPP }=\text { ANPP }+ \text { coarse root }+ \text { fine root }
$$

For the complete forest NPP estimates, it was assumed (Raich and Nadelhoffer 1989) that aboveground litter fall $=$ fine root production. Stump plus coarse root biomass was calculated using ratios of stump/ root biomass to above-stump biomass (Wharton et al. 1997, 1998) for 
species lacking such equations. These ratios ranged from 0.1844 to 0.2109 and were created separately for evergreen and deciduous species for different tree size classes.

Cell ID $=6000$ s (Jenkins et al. 2001) - The potential NPP were calculated based on the FIA data (see description of FIA above) for the northeastern states (Jenkins et al. 2001). The 2640 plots meeting the six criteria (measured twice; timberland; no logging since the last measurement; no damage by insects, disease, or fire since the last measurement; not planted; and basal area $>20$ $\mathrm{m} 2 / \mathrm{ha}$ ), were used in the analysis. Total NPP was the sum of wood production, fine litter fall, and fine root production. Litter fall data were from the database compiled by Post and co-workers (see Jenkins et al. 2001) for plots falling within the region studies based on vegetation types. Fine root production was assumed to equal fine litter fall (Raich and Nadelhoffer 1989). The plot-based estimates of biomass and NPP were aggregated to the $0.5^{\circ}$ grid cell. A weighted average for each $0.5^{\circ}$ cell was computed from the per-unit-area biomass and NPP estimates developed for each plot based on the area expansion factor describing the number of acres represented by that plot. The aggregation was conducted for each $0.5^{\circ}$ grid cell using plots whose centers fell within that cell (Jenkins et al. 2001).

Cell ID $=7000$ s (Krankina et al. 2001) - Forest inventory data in both the U.S. and Russia were used for estimating NPP by Olga Krankina. For Russia, four inventory blocks with the total area of 843 ha, $99 \%$ of which is occupied by closed canopy forest, were selected randomly from the stand-level database for the Porozhskii ranger district (Krankina et al. 2001). Only forested lands were included in the NPP calculation. The sample contains 124 individual forest stands in a wide range of forest stand ages (15 to 175 years). An area-based estimate of NPP includes 3 steps: (a) calculation of biomass for each forest stand based on wood volume, tree species, and forest age, (b) calculation of NPP base on biomass and age of each stand, and (c) calculation of NPP for the entire sample and for several forest stand categories within the sample.

ANPP $\left(\mathrm{gC} / \mathrm{m}^{2} / \mathrm{y}\right)$ was calculated for each individual stand polygon based on stand biomass and age using the regression equation developed by Gower et al. (2001) and total NPP was calculated from ANPP (Gower et al. 2001):

$$
\begin{aligned}
& \text { ANPP }=56+2.31 * \text { BIOMASS } / \text { AGE }(\mathrm{r} 2=0.68) \\
& \text { TNPP }=114+1.21 \text { ANPP }(\mathrm{r} 2=0.66)
\end{aligned}
$$

For the eastern United States, Olga Krankina used the FIA data (see description of FIA data above) to estimate NPP at different scales, for different forest age classes, or different forest types. In the first example, the NPP was estimated and reported based on county-level summaries of timber volume increment. The approach is less computationally intensive and is useful when county summaries are more readily available. In the second example, the NPP was estimated at $0.5^{\circ}$ scale using tree-level data from the selected plots.

The ANPP was calculated as the sum of aboveground biomass increment (Brown et al. 1999) plus litter fall (4.0 Mg/ha/yr for softwoods and $4.5 \mathrm{Mg} / \mathrm{ha} / \mathrm{yr}$ for hardwoods, respectively). Based on Cairns et al. (1997) study, it was estimated that below ground biomass is $25 \%$ of aboveground biomass and that $90 \%$ of the below ground biomass is in coarse roots. It was assumed that the ratio of coarse root biomass to aboveground biomass is the same as the ratio of coarse root increment to aboveground biomass increment. This resulted in a ratio between coarse root increment and aboveground biomass increment of 0.225 . Fine root production was assumed to be equal to fine litter fall production (Raich and Nadelhoffer 1989). As a result, the total NPP was calculated as the sum of ANPP, coarse root, and fine root production. 
Cell ID $=8000$ s (Sala et al. 1988) - A data set collected by the USDA Soil Conservation Service (SCS) at 9498 sites throughout the Central Grassland region of the United States (Joyce et al. 1986). For each site, the database contains estimates of primary production for favorable, unfavorable, and average years, as well as a description of the soil profile that includes texture of the A horizon. Primary production included the aboveground parts of all plants (except mosses and lichens) produced during a single growth year, regardless of accessibility to grazing animals.

The regional pattern of ANPP was analyzed by grouping sites into 100 areas that represent the MLRAs within each state, as defined by the SCS. The average of the ANPP of all the sites within a state's MLRA determine its ANPP. Long-term averages of monthly temperature and precipitation were retrieved for locations near the geographical center of each MLRA. Soil waterholding capacity for each of 9498 sites was estimated from soil texture information. The controls of primary production at the site level were evaluated by multiple regression analysis between ANPP estimates and soil water-holding capacity and climatic variables. As a result, ANPP was estimated as:

$\mathrm{ANPP}=0.6 *(\mathrm{APPT}-56)$, where APPT is annual precipitation in $\mathrm{mm}$.

Cell ID $=$ 9000s (Prince et al. 2001) - Crop NPP in the U.S Midwest states 1992 and the state of Iowa (1982-1996) was estimated from the National Agricultural Statistics Service (NASS, Prince et al. 2001). The counties selected in the U.S. Midwest states must have 50\% or more land used in agriculture and less than 20\% land in forest cover. The overall approach included: (a) estimation of cropland NPP through the use of harvested yield statistics (provided by the National Agricultural Statistics Service), (b) conversion to dry weight, and (c) calculation of the remaining biological yield estimates using harvest indices and shoot:root biomass ratio to estimate below ground allocation. County-level data were aggregated to $0.5^{\circ}$ cell size. NPP values of grid cells crossing county boundaries were calculated with an area weighting method. For Midwest states' NPP, only cells completely within the boundary of the study area were reported.

Cell ID $=$ 10000s (Turner et al. 2000) - The study was conducted over a $96 \mathrm{~km}^{2}$ area of predominantly coniferous forest, centered on the H.J. Andrews Experimental Forest in western Oregon, to estimate NPP and net ecosystem productivity (NEP). One factor strongly related to carbon pools and flux in these forests is stand age class (Turner et al. 1995). A high spatial resolution $(25 \mathrm{~m})$ digital map of stand-age class derived from satellite remote sensing was available for the study area (Cohen et al. 1995). NPP, NEP, and biomass carbon estimates for each stand age class were therefore multiplied by the representative areas of each age class.

A simple majority filter was used to assign an age class to each grid cell at the coarser resolutions. In the majority rule aggregation algorithm, the cover type with the greatest frequency of 25-m subcells in the coarse-resolution cell determines the label for the coarse-resolution cell. In the case of a tie, a random selection is made among the subcells.

The development of the NPP and biomass estimates for each land cover class was based on data in the literature. The trends in woody biomass production were from a stand-level carbon budget for medium productivity PNW west-side Douglas-fir stands (Turner et al. 1995). Biomass estimates and productivity for other ecosystem components were based on previous studies in PNW coniferous forests (Grier and Logan 1977, Turner and Long 1975, Gholz et al. 1985, Vogt 1991). The NPP estimate for the closed agriculture class was a regional average for agricultural land and the semi-open agriculture class was assigned an NPP of half that amount. The ranges for NPP and biomass in the closed forest classes were based on stand-level carbon budgets for low and high productivity PNW west-side Douglas-fir stands (Turner et al. 1995). 
Cell ID $=11000$ s (Gill et al. 2001) - ANPP was a function of annual precipitation in the Great Plains region of United States. While BNPP was estimated from ANPP.

$$
\begin{aligned}
& \text { ANPP }=-34+(0.6 * \text { Mean Annual Precip. }) \\
& \text { BNPP }=\text { BGbiomass } * \text { RTratio } * \text { RTrate }
\end{aligned}
$$

Where RTratio = root: live:total matter $=0.6, \mathrm{RTrate}=$ root turnover rate $(3$ options determined by ANPP, BGbiomass was estimated from ANPP and mean annual temperature.

Cell ID = 13000s (Brown et al. 1999) - Brown et al. (1999) provided estimates of annual mean aboveground wood increments for both hardwood and softwood at the county level using FIA inventory data (see description of FIA data above) in the eastern United States (33 states). They selected those counties with forest cover $>75 \%$ to estimate ANPP and TNPP at $0.5^{\circ}$ resolution. The estimation included several steps at county level: (a) leaf litter fall was calculated (Lonsdale 1988) after the county's latitude value at the centroid point was identified as

$$
\log \mathrm{Y}=-0.011 \mathrm{~L}+0.81 \quad\left(\mathrm{r}^{2}=0.42\right)
$$

where $\mathrm{Y}=$ leaf litter fall production $(\mathrm{Mg} / \mathrm{ha} / \mathrm{yr})$ and $\mathrm{L}=$ latitude in decimal degrees; (b) fine root production was assigned based on the common assumption that leaf litter fall can be used to estimate fine root production (Raich and Nederhoffer 1989); (c) coarse root production was estimated as $22.5 \%$ of aboveground woody increment (Krankina et al. 2001); (d) ANPP = annual mean aboveground wood increments + (a); (e) TNPP $=(d)+(b)+(c)$; and (f) ANPP and TNPP for those $0.5^{\circ}$ cells that are entirely located within the selected counties were calculated using area-based weighting factors. As a result, 62 grid cells were obtained from Brown's study.

Cell ID = 14000s-17000s (Barrett 2001) - In a continental-scale study in Australia, Barrett (2001) developed a statistical model of aboveground and total NPP at $0.25^{\circ}$ cell size. The independent variables were climate, soil, and vegetation and the dependent variable was potential NPP in the absence of agricultural activities for eight vegetation cover classes. Climate variables were monthly maximum and minimum temperatures and rainfall. The 1:2,000,000 Atlas of Australian Soil provided soil depth class and gross nutrient status of the soil. A two-step process was adopted for developing the least square models: (a) combinations of independent variables were iteratively added and removed until the variance 'explained' by each of the regression models for NPP was maximized, and (b) the regression coefficients of these models were then scrutinized to establish their validity. We aggregated Barrett's NPP into a total of $25500.5^{\circ}$ cell using GIS focal mean function and selected 615 cells (with the majority class occupied $>90 \%$ area of a $0.5^{\circ}$ cell) into the GPPDI data set.

Cell ID = 18000s (Zheng et al. 2001b) - Hame et al. (1997) estimated total plant biomass (TPB) of conifer-dominated boreal forest by establishing and testing relationship between ground measurements and high-resolution satellite data Thematic Mapper (TM) in two small areas in Southern Finland. The method was then applied to a large area (Northern Europe in general) after the digital number values between TM and AVHRR channels were calibrated over the entire area from the west coast of Norway to the Ural Mountains in Russia.

We produced NPP maps for Finland and Sweden at $1-\mathrm{km}$ and $0.5^{\circ}$ cell sizes based on Hame et al.'s (1997) TPB estimates and ground measured National Forest Inventory (NFI) data in Sweden through allometric relationships and statistical models. All NFI data (660) come from sampled plots over a 5-year period (1994-1998), including both temporary and permanent ones. The main 
differences between temporary and permanent plots are that the permanent plots are revisited every 5 to 10 years. The permanent plots are also larger $(10 \mathrm{~m}$ radius vs. $7 \mathrm{~m})$ (Kepm 2000, pers. comm., University of Lund). All plots are located separately in three $0.5^{\circ}$ cells, centered at $65.25^{\circ}$ $\mathrm{N}$ and $20.25^{\circ} \mathrm{E}, 61.25^{\circ} \mathrm{N}$ and $15.25^{\circ} \mathrm{E}$, and $57.25^{\circ} \mathrm{N}$ and $13.25^{\circ} \mathrm{E}$. Our overall approach included (1) deriving allometric relations for conifer-dominated boreal forests using the NFI data, (2) converting the TPB $(\mathrm{kg} / \mathrm{ha})$ to annual stem increment $\left(\mathrm{m}^{3} / \mathrm{ha}\right)$, (3) estimating total and leaf litter fall production from statistical models (Lonsdale 1988), (4) mapping ANPP and TNPP at 1-km grid cell based on widely used assumptions for the relationship between BNPP and ANPP (Raich and Nadelhoffer 1989; Jenkins et al. 2001; Krankina et al. 2001; Barrett 2001; Zheng et al. 2001a), and (5) aggregating 1-km cell NPP to $0.5^{\circ}$ grid cell. Eighty-two $0.5^{\circ}$ NPP cells were included into the GPPDI data set. These cells met three criteria: (a) within the coniferous forest zone (i.e., south of $66^{\circ} \mathrm{N}$ latitude); (b) within each of the 82 cells, forest cover was $>80 \%$; and (c) evergreen needleleaf forest was $>50 \%$ area of an entire $0.5^{\circ}$ cell (Zheng et al. 2001b).

Cell ID $=19000$ s (Diallo et al. 1991) - Diallo et al. (1991) reported that in Senegal ANPP could be reasonably estimated from seasonally integrated NDVI derived from the AVHRR. Values of $r^{2}$ between annual ANPP and NDVI from 1987 to 1997 ranged from 0.52 to 0.83 (Diallo pers.

comm. 2000). Homogeneous $10 \times 10 \mathrm{~km}$ ground sites representing the major geomorphological types within the study area were selected using aerial photographs and soil maps. Measurements of ANPP standing biomass were made at the end of the growing season. A linear transect of $1 \mathrm{x} 1$ $\mathrm{m}$ was stratified into classes depending on vegetation type and three levels of biomass. Visual classification of each meter provided an estimate of the percentage cover of each vegetation type and its component strata in the site. Biomass measurements were made by clipping the vegetation in $1 \mathrm{~m}^{2}$ quadrats placed at random along the line and recording the fresh weight, type, and stratum. Regression models between the final calculated ANPP and NDVI for each of the 11 years were established and extrapolated to the entire country. We calculated mean ANPP over the 11 -year period and aggregated $1-\mathrm{km}$ estimates to $0.5^{\circ}$ cells. Thirty-two $0.5^{\circ}$ cells (majority class $>75 \%$ of a total cell area) were incorporated into the GPPDI data set.

Cell ID $=$ 20000s-21000s (Raich et al. 1991) - A process-based model (TEM) was used for simulating potential total NPP for 5,888 non-wetland grid cells in South America at $0.5^{\circ} \times 0.5^{\circ}$ resolution. Although many of the Class $C$ data used a "model" to scale up the NPP measurements to the $0.5^{\circ}$ cells, these NPP estimates are the farthest removed from field measurements; however, the TEM model was specifically calibrate for the South American region. However, we acknowledge that modeling approach may be too similar to many of the biogeochemical regional models and that comparisons between models and these NPP estimates may be problematic. Seven general vegetation types were defined in the study area. The model application involved two steps. The first was model calibration during which the values of rate-controlling parameters were selected so that they were consistent with site-specific data for each of the vegetation types in the region. The second step was the spatial extrapolation during which the fully parameterized model was used in conjunction with geographically referenced information on climate, soils, and vegetation to estimate carbon flux in each of the 5,888 cells. In brief, the model was specifically tuned up for representing vegetation types based on site-specific data provided in Appendix 2 of the Raich et al. (1991) paper. In the GPPDI data set, we only reported the TNPP for 1510 cells in which the dominated land cover type accounted for $>90 \%$ of a cell's total area based on Hansen et al. (2000b).

Cell ID = 22000s (Jiang et al. 1999) - A database for China's forests was assembled with biomass and NPP data from more than 1000 plots together with volume growth data from more than 5,500 permanent plots (Forestry Ministry of China 1994). Contemporary Chinese classification of forest recognized 33 distinct classes of forest (Wu 1980). The NPP calculations 
presented used these classes for statistical analyses with each forest type represented by at least 30 to 50 plots. As a result, a polygon cover containing more than 6,500 polygons for the entire country was produced. The polygon cover was converted to grid cover at 1-km cell resolution. Furthermore, the 1-km NPP file was aggregated to $0.5^{\circ}$ cell size using Arc/Info focal mean function. Finally, only $990.5^{\circ}$ cells within which forest cover accounted for $\geq 90 \%$ of the cell area based on the 1-km global land cover classification system presented by Hansen et al. (2000b) and included in the GPPDI data set.

\section{DATA QUALITY ASSESSMENT}

The overall goal for the quality assessment (QA) and outlier analysis (Sect. 5) was to ensure that the set of NPP and associated driver data where complete and consistent. Our approach was to examine patterns of the NPP associated with geography, biome types, and environmental drivers prior to distributing the model driver data for the EMDI I workshop. We looked at a variety of scatter plots and sorted data listings to detect potential inputting or process errors or unreasonable values. We discovered and corrected wrong units of measure, missing key values, wrong coordinates, duplicate entries, and processing errors. We have summarized below comparisons between site-specific data and estimates for sites extracted from global databases for elevation, climate, soils, and land cover. After the EMDI I workshop, we were able to incorporate input from the EMDI participants and to use model results in examining patterns associated with the model outputs (Sect. 5). The results of the QA and outlier checks are data sets that we have a high degree of confidence that the data are reasonable, consistent, and as complete as possible.

Elevation - Most of the Class A sites have an associated elevation (112 records or 74\%) as described in the original literature, and the remainder were estimated using the DEM. For those sites with and elevation, there was a fairly good correspondence between given and estimated elevation $\left(r^{2}=0.79\right)$, with an even grouping around a 1:1 line of fit. There were 817 Class B sites that have an associated measured elevation, ELEV_GIV (about $50 \%$ of the total number of sites) (Fig. 4). There were a few outliers that the difference between ELEV_GIV and ELEV_DEM exceeded $1000 \mathrm{~m}$. Regression analysis demonstrated the data were reasonable good $\left(\mathrm{r}^{\overline{2}}=0.75\right)$. The site-specific elevation derived from literature was used for the final ELEV variable, with the elevation values derived from the DEM used to fill in the "gaps" of data. Both the mean and standard deviation of ELEV_DEM are available for Class C cells, based upon the global elevation data.

Soils - Twenty-seven of the Class A sites had site-specific soils data, such as estimates of soil texture or a soil type name, as compiled by Jonathan Scurlock through the ORNL NPP project. The site-specific soil texture data were compared with that extracted from the IGBP soils database. Scatter plots of sand, silt, and clay showed very weak correlations between the sitespecific and globally interpolated data; $\mathrm{r}^{2}<0.1$ for silt and clay; $\mathrm{r}^{2}<0.15$ for sand. For additional QA of the soils, we created various scatter plots of the soil parameters with each other to determine outliers, transitions, and possible "gaps" in the data, etc. The comparisons included the following plots between most all combinations of sand, silt, clay, BD, FC WP, PAWC, SOILC, SOILN, and PH (see table above for variable names): We also confirmed that the sum of the soil particle-size fractions (sand + silt + clay) was equal to $100 \%$. 


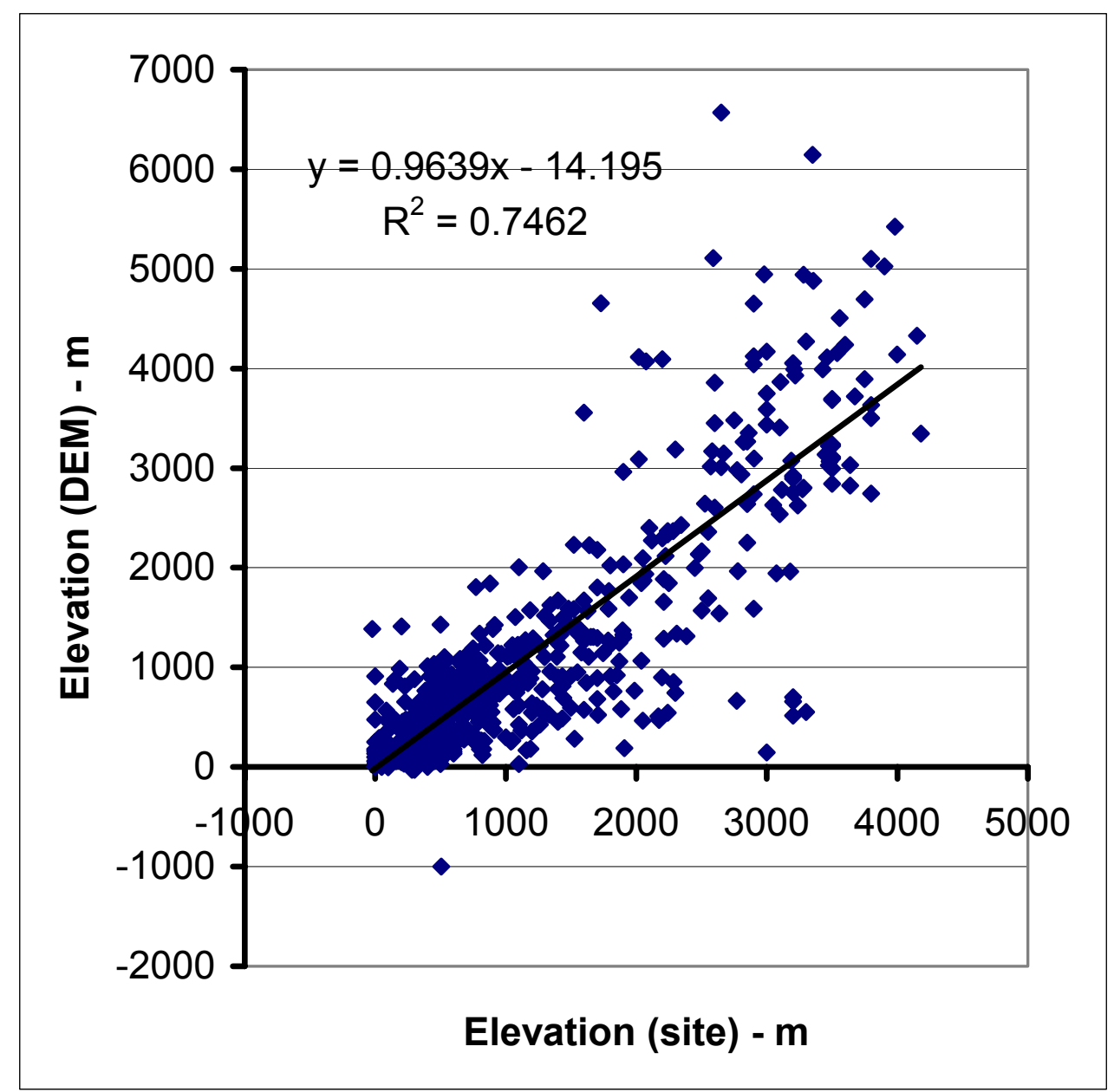

Fig. 4. Site-specific elevation versus elevation derived from global DEM for 817 Class B sites with elevation acquired from literature.

Climate - As a QA check for the site versus global climate data, scatter plots and regression analysis were done. We created scatter plots to compare average annual temperature and annual precipitation between the gridded PIK data and the site-specific data (Figs. 5-8). Approximately $75 \%$ of the Class A sites had both site and global climate data. Temperature data were strongly correlated $\left(r^{2}=0.98\right)$ while precipitation data were moderately well correlated $\left(r^{2}=0.66\right)$. The few sites for which precipitation or temperature were poorly correlated fell in locations in or close to coastal or tropical areas and islands. Approximately $20 \%$ of the Class B sites had both site and global climate data. Temperature data were well correlated $\left(\mathrm{r}^{2}=0.93\right)$ and precipitation data were moderately well correlated $\left(\mathrm{r}^{2}=0.63\right)$.

Land cover - The biomes from the NPP database were compared with the landcover from UMD. There was general consistency, with the landcover types based on the global data set agreeing with the site-specific vegetation information. The total percentages and averages from the sites showed correct representation of how it was reported. The average agreement between the global and site-specific types was around $60 \%$ with a range of 35 to $86 \%$ based on our best effort to match the two classification systems.

Class A/B and C intercomparison - For QA of the Class $\mathrm{C}$ cells, we compared temperature, precipitation, and elevation of the Class $\mathrm{C}$ grid cells with the Class A and $\mathrm{B}$ site-specific data for 
those sites that were located within those cells. There were 22 Class A and 217 Class B sites that were associated with Class $C$ cells. The plots were very close to an exact 1:1 line with strong correlations $\left(r^{2}\right.$ generally $\left.>0.95\right)$.

NPP data - The NPP data quality assessment in all three classes included the following:

- checking for duplicate data at the same site from different sources;

- sorting and generating statistics to check for consistency and completeness; and

- plotting NPP against temperature, precipitation, elevation, and latitude within biomes to check for consistency. We looked for inconsistencies by using symbols to identify the biome or source of each point for within scatter-plots.

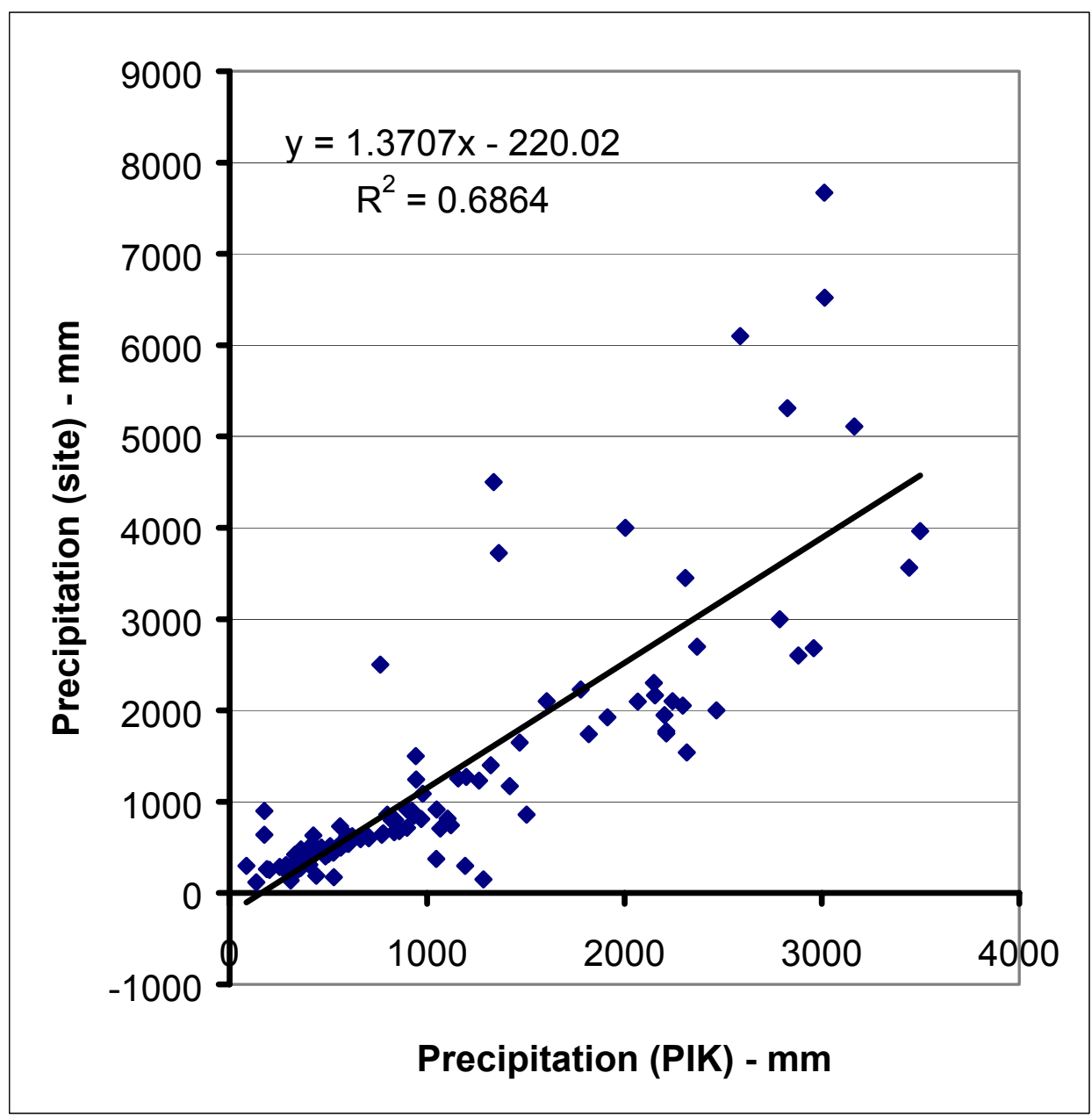

Fig. 5. Site-specific precipitation versus precipitation derived from global climate database for Class A sites with precipitation acquired from literature. 
We compared the widely used Miami model (Leith 1972) with the measured NPP for Class A, B, and $\mathrm{C}$ data. From analyzing the scatter plots and normal probability plots of the Miami model and measured NPP, we noticed that the Miami model estimates of potential NPP were generally higher than the measured NPP, which may reflect the calibration of the model to sites more productive for given temperature and precipitation than the general population of sites.

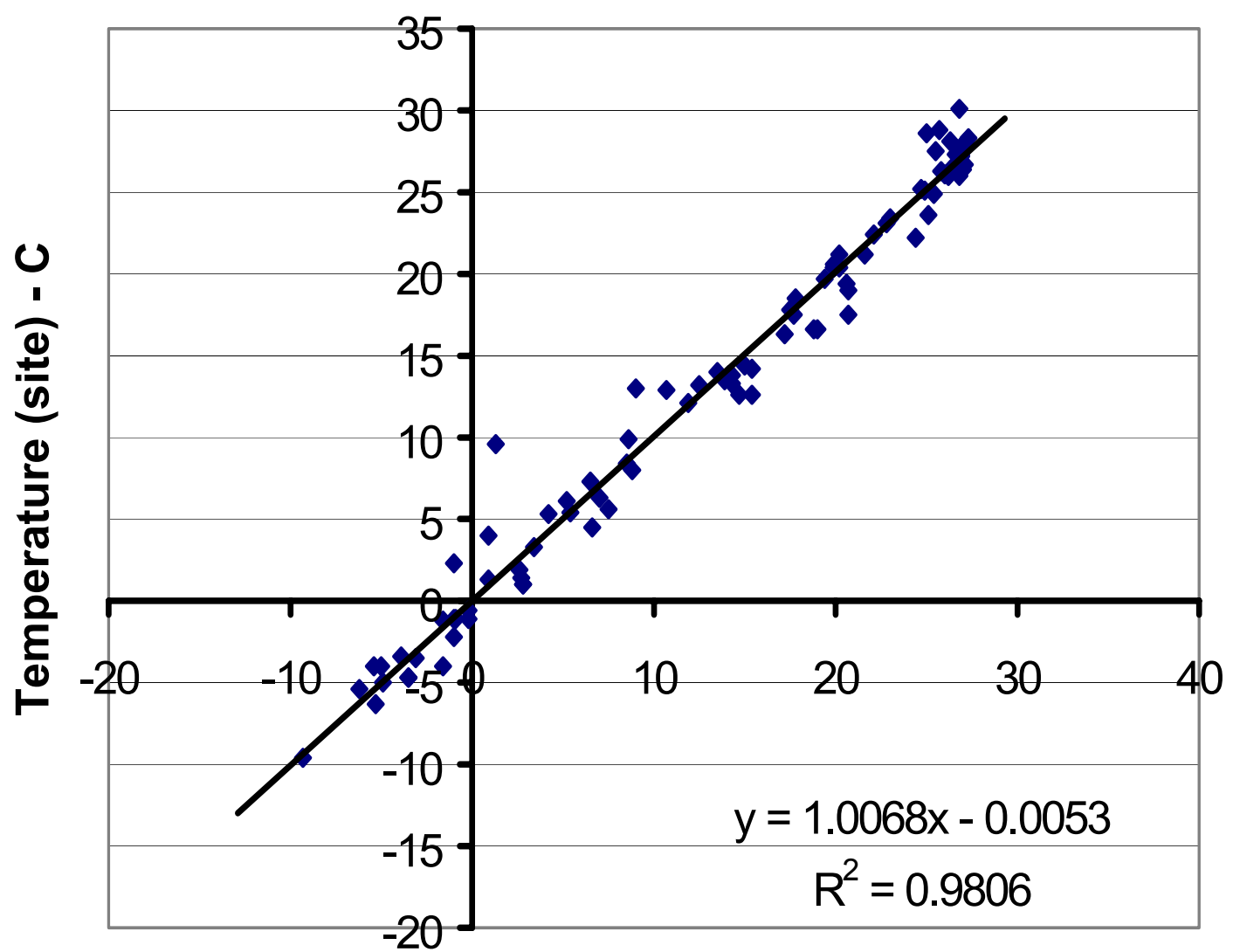

\section{Temperature (PIK) - C}

Fig. 6. Site-specific temperature versus temperature derived from global climate database for Class A sites with temperature acquired from literature. 


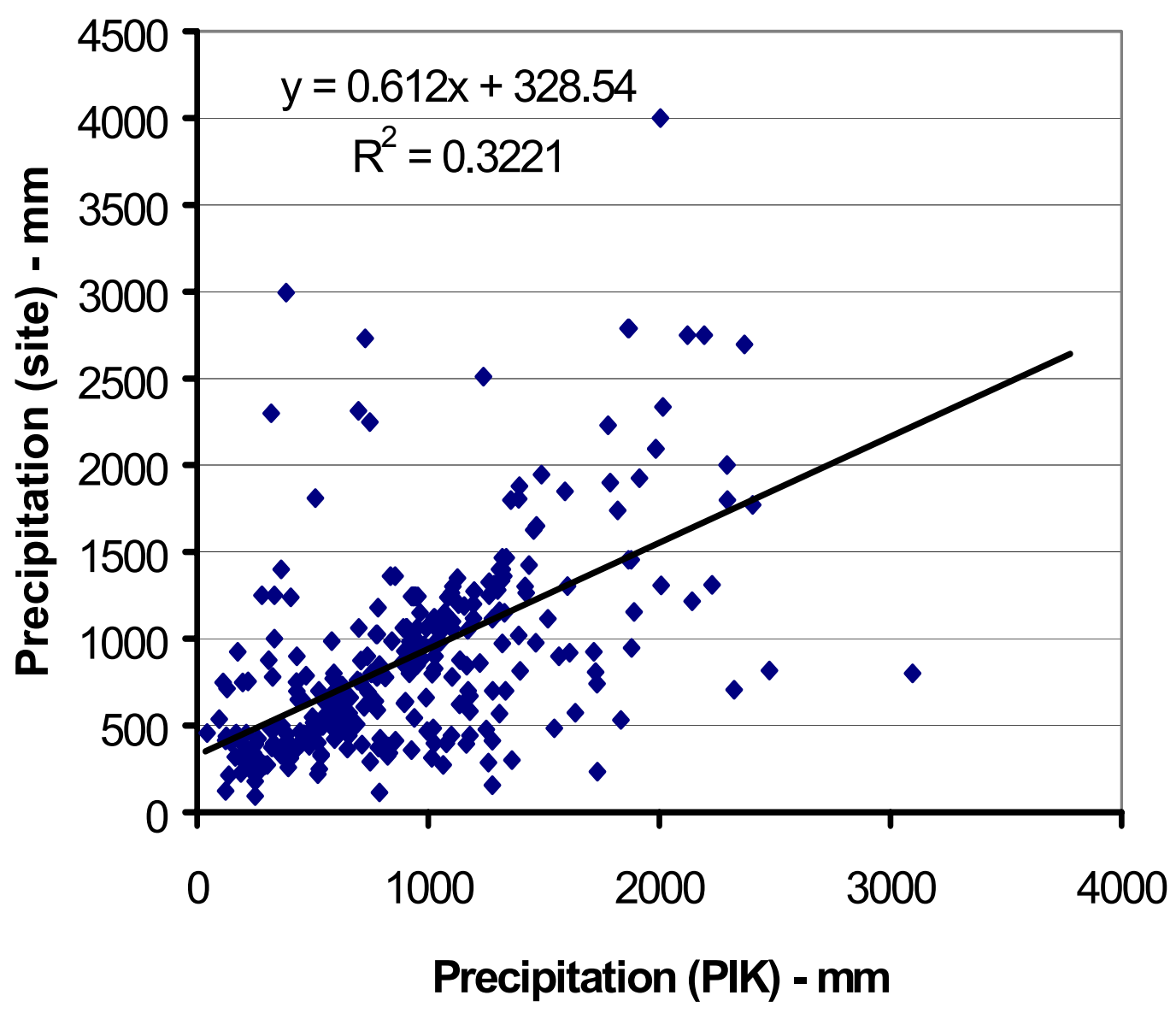

Fig. 7. Site-specific precipitation versus precipitation derived from global climate database for Class B sites with precipitation acquired from literature. 


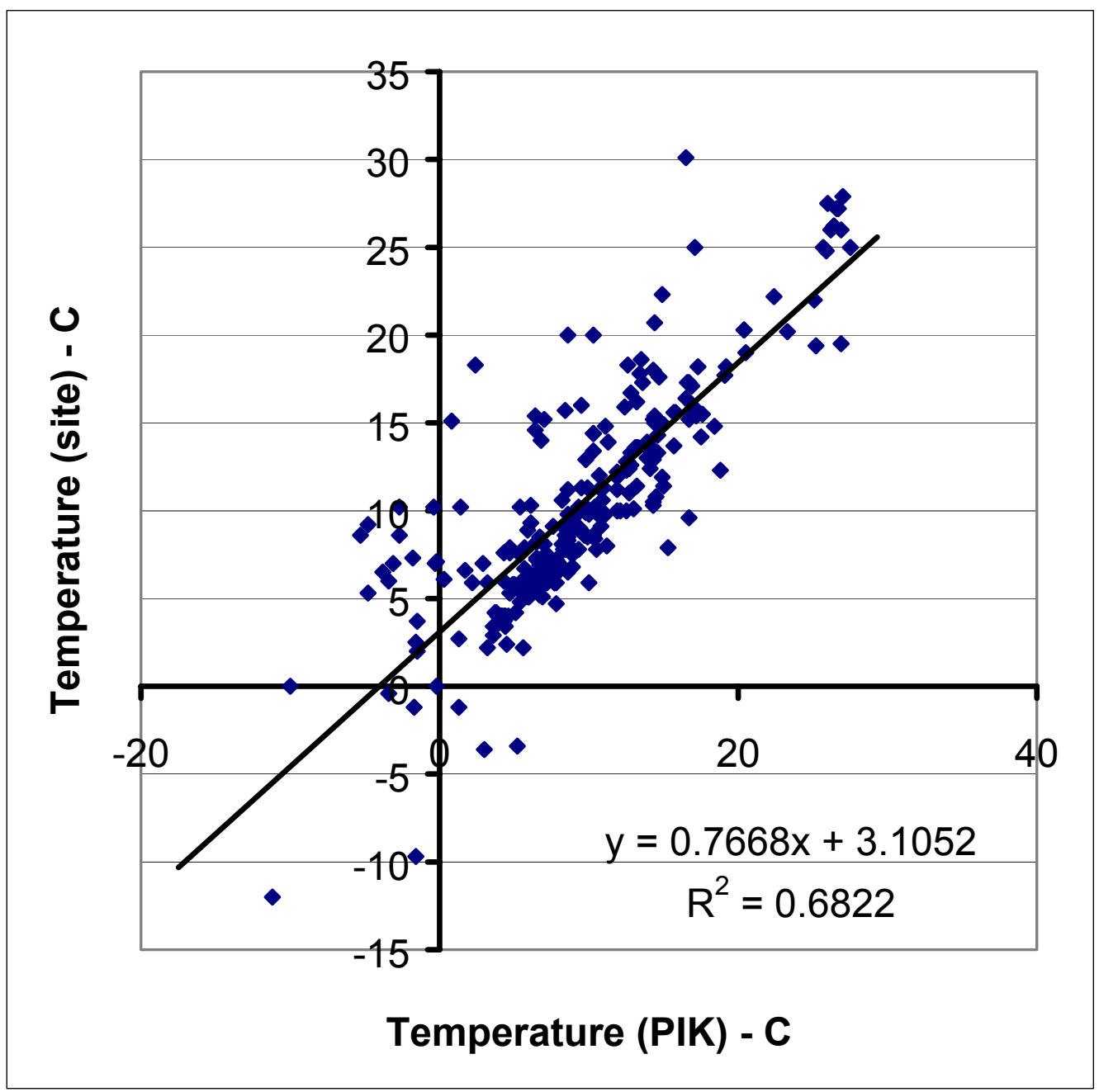

Fig. 8. Site-specific temperature versus temperature derived from global climate database for Class B sites with temperature acquired from literature.

\section{OUTLIER ANALYSIS}

\subsection{OVERALL APPROACH}

The EMDI I Workshop (December 1999) included a variety of models, including biogeochemical, satellite-driven, detailed process, and Dynamic Global Vegetation Model (DGVM) types. Initial results showed general agreement between models and data but with obvious differences that indicated areas for potential data and model improvement. Much of the EMDI Workshop was devoted to looking at potential outliers and harmonizing some of the driver data, especially land cover or vegetation types. Our goal for the outlier analysis is to produce a consistent set of NPP measurements with associated environmental driver data that can be used for regional model development and validation. 
What comprises an outlier? - For the purposes of this discussion, an outlier is defined as a data point considered to be unrepresentative of its location or land cover type, or otherwise "difficult" to represent in a generalized NPP model, such as those used in the EMDI exercise. There may be a number of reasons why an NPP data point is designated an outlier within this EMDI context, even when the data themselves are considered quite reasonable and representative of their location.

Our analysis is based upon the complete package of NPP data and model drivers (climatology, soils, land cover type), not just the measured NPP data alone. Thus any problems experienced by the algorithms to produce consistent driver data (e.g., high elevation or highly incised topography, failure of the algorithms to represent the influence of the Gulf Stream on northern Scandinavia) may result in a point being labeled an outlier. Some characteristics peculiar to certain sites (e.g., a short growing season in "cold desert" grasslands) also resulted in outlier designation, since it may be hard to generalize the climate for such sites (e.g., mean annual temperature would appear too low in relation to NPP).

The process of synthesis, review and generalization of data sets may also have resulted in some points being designated outliers because of differences in methodologies for estimating NPP. For this first phase of EMDI, the large number of available NPP data allowed the designation of outliers to be fairly liberal. Future model-data intercomparison may require a more selective and conservatively justified elimination of outliers, in order to provide a more stringent test of the models.

Model ensemble - The ORNL group reviewed the data extensively prior to EMDI by looking at scatter plots and data outside of reasonable limits as described in Sect. 4. However, the Workshop provided the initial model results to compare with the observed NPP data. An ensemble NPP value was calculated for each site as the average of the 11 Class A models (AVIM, BGC, CARAIB, CENTURY, GLO-PEM, GTEC, IBIS, LPJ, PNET, STOMATE, and VECODE) and 8 Class B models (AVIM, CARAIB, CENTURY, GLO-PEM, IBIS, PnET, STOMATE, and VECODE). An ensemble NPP value was calculated for each Class $C$ cell as the average of the 4 models including AVIM, IBIS, PnET, and VECODE. If the model ensemble NPP value was based on less than 3 model outputs for Class A or B sites, or less than 2 outputs for Class C cells, then the model average for that site or cell was dropped.

In addition, an ensemble AET (actual evapotranspiration) value was calculated based on the average of AET provided by five of the models for Class A (CARAIB, CENTURY, IBIS, PNET, GTEC), four of the models for Class B (CARAIB, CENTURY, IBIS, PNET), and two of the models for Class C (IBIS, PNET). If the model ensemble AET value was based on less than 3 model outputs for Class A or B sites or less than 2 for Class C cells, then the AET average for that site or cell was dropped.

Outlier analysis - The power of the statistical-empirical approach is that we can look for inconsistencies of individual sites within the patterns formed by homogeneous groups (i.e., biomes). Often these inconsistencies are not apparent in a review of the literature associated with a specific study. The overall approach used at the EMDI 1 Workshop included the following tests to set outlier flags:

1. Flags based on values outside of reasonable limits as defined at the EMDI I workshop:

$$
\text { ANPP_C }>2000 \mathrm{gC} / \mathrm{m}^{2} / \mathrm{y}, \text { BNPP_C }>2000, \text { TNPP_C }>3000
$$


ELEV $>2500 \mathrm{~m}$ (high-elevation sites were expected to comprise unrepresentative sub-biomes or present problems with the climate extrapolation algorithm)

ANPP $>0.95$ TNPP, BNPP $>0.95$ TNPP (for a site with both above and below ground components)

2. Flags based on NPP values outside of the 0.05 to 0.95 percentiles for each biome calculated assuming a normal distribution of variables:

ANPP, BNPP, TNPP

3. Flags based on climate values outside of the 0.01 to 0.99 percentiles for each biome calculated assuming a normal distribution of variables. In addition, we set some specific limits for some biomes:

Annual temperature and total annual precipitation

Temp $>6 \mathrm{C}$ for boreal forests

Precip $>1000 \mathrm{~mm}$ for desert and tundra

Precip $<1000 \mathrm{~mm}$ for tropical forest

4. Flags based on inconsistencies at a site, such as precipitation reported for the site being different than the precipitation derived from global climate data. These flags were based on calculating the Normalized Error (NE) as the ratio of the difference (predicted - observed) divided by the average (predicted + observed) $/ 2$. Based on the frequency distribution of the ratios, ratios greater than 1.0 were flagged.

Elevation, Precipitation, Temperature

5. Flags based on the comparison of measured NPP versus modeled NPP using the average or ensemble value for all available models. The comparison was based on bias (predicted observed), Normalized Error (predicted - observed) divided by the average (predicted observed ) $/ 2$, and Mean Absolute Error (MAE) - (predicted - observed) divided by the observed. Based on the frequency distributions, bias greater than $\pm 1000 \mathrm{gC} / \mathrm{m}^{2}, \mathrm{NE}$ ratios greater than \pm 1.0 , and MAE ratios greater than \pm 5 were flagged.

NPP vs. MODEL ensemble - Bias

NPP vs. MODEL ensemble - Normalized Error

NPP vs. MODEL ensemble - Mean Absolute Error

6. Flags based on relationships between variables. Linear regression analysis was performed between NPP and average AET (from 4 models), NPP and precipitation, and NPP and temperature. Points falling outside of the 0.95 Confidence Interval about the regression line were flagged.

NPP vs. AET, NPP vs. Prec, NPP vs. Tave

7. Flags based on visual inspection and deviations from the model ensemble values as reviewed at the EMDI Workshop. Those sites identified as outliers at the EMDI Workshop were assigned flags in this analysis.

Critical flags - We assume that sites that have multiple flags have multiple inconsistencies between NPP, driver data, and model predictions, and are therefore more likely to be outliers. 
This seemed to hold true in plots (see below). We also know that some flags deserve more critical weight as indicators of potential problems. We designated flags by assigning a weight of 10 for those critical checks, including NPP inconsistent with model NPP ensemble value, elevation $>2500 \mathrm{~m}$ or $<-100 \mathrm{~m}$, and either site temperature or precipitation inconsistent with that assigned based on the global climate data. We assigned a weight of 100 to the flag indicating heavily managed sites for easy identification.

The value of the overall flag was calculated as the sum of the individual flags. Sites with a sum greater than 5 [all those that were flagged as managed biomes $($ flag $=100)$ or with at least one major flag $($ flag $=10)$ ] were considered outliers for EMDI.

\subsection{CLASS A POINT DATA}

The overall flag value was calculated as the sum of the individual flags as defined in Table 10. Sites with a sum greater that 10 (all those with at least one major flag) were dropped, and those with a sum greater than 4 were considered potential for excluding. A total of 11 records were flagged resulting in a total of 151 records for 81 unique sites. Virtually all the sites identified at the EMDI 1 Workshop (Table 11) as outliers were included in this set. We plotted NPP observed against the modeled NPP ensemble by AET ensemble and by latitude with the plot symbols indicating the magnitude of the flags. In general, the points that had high flag values appeared to be on the fringe of the cluster of points, re-enforcing their outlier status.

Table 10. Flags' names, descriptions, and weights used for Class A records

\begin{tabular}{llc}
\hline \multicolumn{1}{c}{ Flag name } & \multicolumn{1}{c}{ Description } & Weight \\
\hline ELEV_MXF & Elev $>2500$, elev $<-100^{*}$ & 10 \\
MOD_F & (npp_est - modcb_av) / ave $\left(\right.$ npp) $>1^{*}$ & 10 \\
ANPP_P5F & anpp outsite $0.05-0.95$ percentile by biome2 & 1 \\
BNPP_P5F & bnpp outsite $0.05-0.95$ percentile by biome2 & 1 \\
TNPP_P5F & tnpp outsite $0.05-0.95$ percentile by biome2 & 1 \\
ANPPBADF & anpp $>2000 \mathrm{gC} / \mathrm{m}^{2}$, anpp $>95 \%$ tnpp & 1 \\
BNPPBADF & bnpp $>2000 \mathrm{gC} / \mathrm{m}^{2}$, bnpp $>95 \%$ tnpp & 1 \\
TNPPBADF & tnpp $>3000 \mathrm{gC} / \mathrm{m}^{2}$, anppbadf or bnppbadf & 1 \\
AET_RGF & NPP outside 0.95 CI of NPP $=\mathrm{a}+\mathrm{b}^{*}$ AET regression & 1 \\
PREC_RGF & NPP outside $0.95 \mathrm{CI}$ of NPP $=\mathrm{a}+\mathrm{b}^{*}$ PREC regression & 1 \\
TAVE_RGF & NPP outside $0.95 \mathrm{CI}$ of NPP=a+b*TAVE regression & 1 \\
PRECBADF & prec outsite $0.01-0.99$ percentile by biome2 $($ or $>1000$ millimeters & 1 \\
& in desert) & 1 \\
TAVEBADF & temp outsite $0.01-0.99$ percentile by biome2 $(>6$ in boreal forests) & 1 \\
\hline
\end{tabular}


Table 11. Class A sites identified as outliers by participants in the EMDI I workshop

\begin{tabular}{|c|c|c|c|c|c|}
\hline No. & Latitude & Longitude & BIOME2 & Site name, country & Comments \\
\hline 1 & -20.27 & 148.12 & Grassland & $\begin{array}{l}\text { Bowen Pertusa, } \\
\text { Queensland, } \\
\text { Australia }\end{array}$ & $\begin{array}{l}\text { Relatively warm/wet, but } \\
\text { low NPP }\end{array}$ \\
\hline 2 & -1.33 & 36.83 & Grassland & Nairobi, Kenya & $\begin{array}{l}\text { Low NPP reported in data } \\
\text { synthesis - may actually be } \\
\text { higher }\end{array}$ \\
\hline 3 & 6.33 & 100.93 & Grassland & Hat Yai, Thailand & $\begin{array}{l}\text { Low NPP reported in data } \\
\text { synthesis - may actually be } \\
\text { higher }\end{array}$ \\
\hline 4 & 18.00 & -66.92 & $\begin{array}{l}\text { DBL } \\
\text { forest / } \\
\text { tropical }\end{array}$ & $\begin{array}{l}\text { Guanica, Puerto } \\
\text { Rico }\end{array}$ & $\begin{array}{l}\text { Low NPP reported in data } \\
\text { synthesis }\end{array}$ \\
\hline 5 & 18.08 & -76.65 & $\begin{array}{l}\text { EBL } \\
\text { forest / } \\
\text { tropical }\end{array}$ & $\begin{array}{l}\text { John Crow Ridge } \\
\text { (Wet Slope), } \\
\text { Jamaica }\end{array}$ & $\begin{array}{l}\text { Low NPP reported in data } \\
\text { synthesis }\end{array}$ \\
\hline 6 & 18.27 & -65.77 & $\begin{array}{l}\text { EBL } \\
\text { forest / } \\
\text { tropical }\end{array}$ & $\begin{array}{l}\text { Luquillo (Pico del } \\
\text { Este), Puerto Rico }\end{array}$ & $\begin{array}{l}\text { Low NPP, high precipitation } \\
\text { (but relatively high } \\
\text { elevation) }\end{array}$ \\
\hline 7 & 29.97 & 76.80 & grassland & Kurukshetra, India & $\begin{array}{l}\text { Very high NPP (previously } \\
\text { fertilized?) }\end{array}$ \\
\hline
\end{tabular}

Summary of outlier analysis of Class A sites - Outlier analysis of Class A sites resulted in the following.

- Assigned consistent biome class to Class A sites (162 records, 87 sites).

- Calculated new NPP ensemble values (11 models).

- Calculated new AET ensemble values (5 models).

- Performed outlier analysis on NPP and driver data (11 different outlier tests).

- Identified a set of 11 of the 162 sites to be excluded, including:

One or more critical flags:

All 11 flagged related to differences with NPP ensemble (bias, NE, MAE).

- Calculated mean driver data and NPP for 81 unique sites from the 151 NPP records.

\subsection{CLASS B POINT DATA}

The value of the overall flag was calculated as the sum of the individual flags as defined in Table 12. Sites with a sum greater than 5 (all those with at least one major flag or a managed site) were considered potential for excluding. A total of 134 of the 2363 records ( $6 \%$ of the total) were dropped because they are managed sites. A total of 353 appeared to be outliers. Virtually all the sites identified at the EMDI I Workshop as outliers were included in this set. The process resulted in a total of 1689 records for 933 sites. We plotted NPP observed against the modeled NPP ensemble by AET ensemble and by latitude with the plot symbols indicating the magnitude of the flags. In general, the points that had high flag values appeared to be on the fringe of the cluster of points, re-enforcing their outlier status. 
Table 12. Flags' names, descriptions, and weights used for Class B records

\begin{tabular}{|c|c|c|}
\hline Flag name & Description & Weight \\
\hline MIXED_F & Mixed biome, measurement biome not $=$ to biomenew & 100 \\
\hline BIOME_F & crops, pasture, plantations, wetlands $* *$ & 100 \\
\hline ELEV $\bar{M} X F$ & elev $>2500$, elev $<-100 *$ & 10 \\
\hline PREC_F & $($ prec - prec_ann $) /$ ave $($ prec $)>1 *$ & 10 \\
\hline TAVE_F & $($ tave - temp_ann $) /$ ave $($ tave $)>1 *$ & 10 \\
\hline MOD_F & $($ npp_est - modcb_av) / ave (npp) $>1 *$ & 10 \\
\hline EMDI_F & Identified at EMDI as an outlier by visual inspection & 10 \\
\hline ANPP_P5F & anpp outsite $0.05-0.95$ percentile by biome 2 & 1 \\
\hline BNPP_P5F & bnpp outsite $0.05-0.95$ percentile by biome 2 & 1 \\
\hline TNPP_P5F & tnpp outsite $0.05-0.95$ percentile by biome 2 & 1 \\
\hline NPP_P- $5 F$ & npp outsite $0.05-0.95$ percentile by biome 2 & 1 \\
\hline ANPPBADF & anpp $>2000 \mathrm{gC} / \mathrm{m}^{2}$, anpp $>95 \%$ tnpp & 1 \\
\hline BNPPBADF & bnpp $>2000 \mathrm{gC} / \mathrm{m}^{2}$, bnpp $>95 \%$ tnpp & 1 \\
\hline TNPPBADF & tnpp $>3000 \mathrm{gC} / \mathrm{m}^{2}$, anppbadf or bnppbadf & 1 \\
\hline AET_RGF & NPP outside $0.95 \mathrm{CI}$ of $\mathrm{NPP}=\mathrm{a}+\mathrm{b}^{*} \mathrm{AET}$ regression & 1 \\
\hline PREC_RGF & NPP outside $0.95 \mathrm{CI}$ of $\mathrm{NPP}=\mathrm{a}+\mathrm{b} * \mathrm{PREC}$ regression & 1 \\
\hline TAVE_RGF & NPP outside $0.95 \mathrm{CI}$ of $\mathrm{NPP}=\mathrm{a}+\mathrm{b} * \mathrm{TAVE}$ regression & 1 \\
\hline ELEV_F & $($ elev_giv - elev_dem $) /$ ave $($ elev $)>1$ & 1 \\
\hline PRECB̄ADF & $\begin{array}{l}\text { prec outsite } 0.01-0.99 \text { percentile by biome } 2 \text { (or }>1000 \text { millimeters } \\
\text { in desert) }\end{array}$ & 1 \\
\hline TAVEBADF & temp outsite $0.01-0.99$ percentile by biome 2 ( $>6$ in boreal forests) & 1 \\
\hline
\end{tabular}

Summary of outlier analysis of Class B sites - Outlier analysis of Class B sites resulted in the following.

- Assigned consistent biome class to Class B sites (2363 records, 1271 sites).

- Calculated new NPP ensemble values (8 models).

- Calculated new AET ensemble values (4 models).

- Assigned unique IDs including MEAS_NUM for all NPP measurements (1-2363) and SITE_NUM for all unique sites by lat/long (1-1605).

- Rounded all lat/long coordinates to two decimal places ( 85 of the 1690 became non-unique).

- Reviewed biome type and flags for multiple measurements for multiple biomes at a site [399 records; dropped 187 because biome for a measurement was inconsistent with biomenew assigned to the site with multiple measurements (e.g., a site with several NPP measurements was assigned biomenew = 'Grassland C3,' but one of the measurements was for a "Crop" which was flagged)].

- Excluded 134 as managed sites (crops, pasture, plantation, and wetlands).

- Performed outlier analysis on NPP and driver data (see Table 12).

- Identified a set of 353 sites to be excluded, including:

One or more critical flags:

164 flagged related to differences with NPP ensemble (bias, NE, MAE)

125 flagged related to high elevation $(>2500 \mathrm{~m})$

35 flagged related to big differences between site and global precipitation

35 flagged related to big differences between site and global temperature

Five or more less critical flags:

Outside of 0.05 to 0.95 percentile by biome

Outside of 0.95 CI determined by regressions with AET, PREC, TAVE.

- Calculated mean driver data and NPP for 933 unique sites from the 1689 measurements. 


\subsection{CLASS C GRID CELLS}

We used the statistical-empirical approach for the expanded Class $\mathrm{C}$ cells as we did for Class A and Class B, with a few minor changes. The modifications to Class $\mathrm{C}$ outlier analysis consisted of the following.

- The previous model ensemble average was replaced by the Miami model for analysis of outliers where regression analysis between total NPP and the Miami model was performed. Points beyond the $95 \%$ Confidence Interval were flagged.

- To be consistent with various model requirements, the crops and bare ground biomes were flagged.

Each flag was assigned a weight of 1 except the critical flags which were assigned a weight of 100 (Table 13). The overall flags' value was calculated as the sum of the individual flags. Sites with a sum greater than 5 were dropped. The $4848(=5164-316)$ records that had a flag sum $<=5$ were used to calculate mean TNPP for 3855 unique sites to form the EMDI II data set.

Table 13. Flags' names, descriptions, and weights used for Class $\mathbf{C}$ records

\begin{tabular}{llc}
\hline \multicolumn{1}{c}{ Flag name } & \multicolumn{1}{c}{ Description } & Weight \\
\hline BIOME_F & biome=crops, bare ground & 100 \\
NPP_F & missing totnpp & 10 \\
ELEV_MXF & elev $>2500$, elev $<-100$ & 10 \\
ANPP_P5F & anpp outsite 0.05 percentile by biome2 & 1 \\
TNPP_P5F & totnpp outsite 0.05 percentile by biome2 & 1 \\
ANPPBADF & anpp $>2000 \mathrm{gC} / \mathrm{m}^{2}$, anpp $<50$ or anpp $>95 \%$ totnpp & 1 \\
TNPPBADF & tnpp $>3000 \mathrm{gC} / \mathrm{m}^{2}$, tnpp $<50$ or anppbadf & 1 \\
PRECBADF & anu_ppt outside $0.01-0.99$ percentile by biome2 (or $>5000$ & 1 \\
& millimeters) & 1 \\
TAVEBADF & anu_avgt outside $0.01-0.99$ percentile by biome2 (or $\left.>30.0^{\circ} \mathrm{C}\right)$ & 1 \\
TEMPFLAG & totnpp outside $0.95 \mathrm{CI}$ of totnpp=a+b*PREC regression & 1 \\
PRECFLAG & totnpp outside $95 \mathrm{CI}$ totnpp $=\mathrm{a}+\mathrm{b}^{*}$ TAVE regression & 1 \\
NPPFLAG & totnpp outside $95 \mathrm{CI}$ totnpp $=\mathrm{a}+\mathrm{b}^{*}$ MNPP_C regression & 1 \\
MOD_F & (totnpp - mnpp_c) / ave $(\mathrm{npp})>1$ & $>1$ \\
\hline
\end{tabular}

Summary of outlier analysis of Class $\mathbf{C}$ cells - Outlier analysis of Class $\mathrm{C}$ sites resulted in the following:

- 5164 records (3980 sites) received data for Class C cells from Steve Prince and Daolan Zheng (University of Maryland)

- 1830 records for 1788 sites have missing ANPP (Prince, Raich, Tieszen, Jiang)

- 36 sites were lacking total NPP but had ANPP (mostly from CSE/Diallo)

- 33 records (17 sites) had two different biome classifications for same cell (lat/long are the same) (Brown and Parton data)

- 316 records had flag sums $>5$ based on outlier analysis on NPP and driver data

One or more critical flags (flag sum>100), 292 records:

- 227 flagged related to managed sites or not applicable (e.g., crops, bare ground)

- 39 flagged related to high elevation $(>2500$ or $<-100)$ 
- 36 sites lacking total NPP

\section{Five or more less critical flags (flag sum $>5$ and $<100$ ), 24 records:}

- Outside of .05 to .95 percentile by biome

- Outside of $95 \%$ CI determined by regressions with ANU_PPT, ANU_AVGT, MNPP_C

- Calculated mean driver data and NPP for 3855 unique cells

- Create subsets of Class C cells - The 3855 records were sorted by biome and TNPP and alternating records assigned to the $\mathrm{C} 1$ and $\mathrm{C} 2$ subsets. The $\mathrm{C} 1$ subset (1928 cells) will be used for the blind runs for model calibration and the C2 subset (1927 cells) for the final model runs.

\section{SUMMARY}

The results of the QA (Sect. 4) and outlier checks (Sect. 5) produced data sets of NPP and associated driver data that are as reasonable, consistent, and as complete as possible. Our approach was to examine patterns of the NPP associated with geography, biome types, environmental drivers, and preliminary model outputs to identify and correct (or flag) unreasonable values. The result of this sequence of checks is summarized in Table 14, and the formats and organization of the data sets provided in Appendix D.

Table 14. Maturation of the EMDI I data set

\begin{tabular}{|c|c|c|c|c|}
\hline \multicolumn{3}{|c|}{ Number of records } & $\begin{array}{l}\text { Date } \\
\text { compiled }\end{array}$ & Description \\
\hline Class A & Class B & Class C & & \\
\hline 162 & 2363 & 2768 & $\begin{array}{l}\text { June/July } \\
1999\end{array}$ & $\begin{array}{l}\text { Initial set of GPPDI NPP measurements, many sites } \\
\text { with multiple measurements }\end{array}$ \\
\hline 150 & 1690 & 2110 & $\begin{array}{l}\text { October } \\
1999\end{array}$ & Initial set of unique sites used to extract driver data \\
\hline 87 & 1271 & 1622 & $\begin{array}{l}\text { December } \\
1999\end{array}$ & Set of sites with both NPP and driver data \\
\hline 151 & 1689 & 2696 & $\begin{array}{l}\text { March } \\
2000\end{array}$ & NPP measurements passing outlier review \\
\hline 81 & 933 & 1637 & $\begin{array}{l}\text { March } \\
2000\end{array}$ & $\begin{array}{l}\text { Set of sites with outliers excluded and means of } \\
\text { multiple measurements }\end{array}$ \\
\hline \multicolumn{5}{|c|}{ Expanded Class C Cells } \\
\hline \multirow{3}{*}{\multicolumn{2}{|c|}{$\begin{array}{l}\text { No change in data } \\
\text { for the Class A and } \\
\text { B Sites after March } \\
2000\end{array}$}} & 5,164 & $\begin{array}{l}\text { October } \\
2000\end{array}$ & $\begin{array}{l}\text { Expanded set of Class C grid cell NPP measurements, } \\
\text { some sites with multiple measurements (includes } \\
2396 \text { new values in addition to the } 2768 \text { available in } \\
\text { July 1999) }\end{array}$ \\
\hline & & 3,980 & $\begin{array}{l}\text { October } \\
2000\end{array}$ & Set of unique Class $\mathrm{C}$ grid cells with driver data \\
\hline & & 3,855 & $\begin{array}{l}\text { January } \\
2001\end{array}$ & $\begin{array}{l}\text { Expanded set of Class C grid cell NPP measurements } \\
\text { passing outlier review }\end{array}$ \\
\hline
\end{tabular}




\section{ACKNOWLEDGEMENTS}

The Terrestrial Ecology Program within NASA's Office of Earth Science (U.S. National Aeronautics and Space Administration, Office of Earth Science, Terrestrial Ecology Program, Activity No. 46WM16401) supported the NPP data compilation. We especially appreciate Dr. Diane Wickland's support during this project. A portion of this work is the product of several workshops conducted in 1998 and 1999 at the NCEAS, a center funded by the National Science Foundation (Grant \# DEB-9421535), the University of California at Santa Barbara, and the state of California. In addition, NCEAS provided support for data organization and distribution to support EMDI I and support to host EMDI II. The Global Analysis, Interpretation, and Modeling Task Force of the International Geosphere-Biosphere Programme provided sponsorship for both EMDI Workshops.

We especially thank R. B. Cook, W. M. Post III, and C. T. Garten for their helpful review comments and Linda O'Hara for her editorial review.

This data compilation depended on the contributions of many individuals, both those providing NPP data and those contributing as part of EMDI (see Appendix A for list of names). We are grateful that these individuals are willing to not only share their data but also to provide the documentation to ensure that others can use the data.

\section{REFERENCES}

\subsection{DATA CITATIONS}

The following is a list of citations for the 75 published net primary productivity data sets available from the ORNL DAAC (http://www.daac.ornl.gov/) that were associated with activities described in this report.

\section{ORNL Collection of Individual Sites}

\section{Tundra}

Shaver, G. R. 2001. NPP Tundra: Toolik Lake, Alaska, 1982. Available on-line [http://www.daac.ornl.gov/] from Oak Ridge National Laboratory Distributed Active Archive Center, Oak Ridge, Tennessee, U.S.A.

Tieszen, L. L. 2001. NPP Tundra: Point Barrow, Alaska, 1970-1972. Available on-line [http://www.daac.ornl.gov/] from Oak Ridge National Laboratory Distributed Active Archive Center, Oak Ridge, Tennessee, U.S.A.

\section{Grassland}

Bertiller, M. 1998. NPP Grassland: Pampa de Leman, Argentina, 1980-1982. Available on-line [http://www.daac.ornl.gov/] from Oak Ridge National Laboratory Distributed Active Archive Center, Oak Ridge, Tennessee, U.S.A. 
Christie, E. K. 1999. NPP Grassland: Charleville, Australia, 1973-1974. Available on-line [http://www.daac.ornl.gov/] from Oak Ridge National Laboratory Distributed Active Archive Center, Oak Ridge, Tennessee, U.S.A.

Coupland, R. T. 1999. NPP Grassland: Matador, Canada, 1968-1971. Available on-line [http://www.daac.ornl.gov/] from Oak Ridge National Laboratory Distributed Active Archive Center, Oak Ridge, Tennessee, U.S.A.

Daubenmire, J. 1997. NPP Grassland: Canas, Costa Rica, 1969-1970. Available on-line [http://www.daac.ornl.gov/] from Oak Ridge National Laboratory Distributed Active Archive Center, Oak Ridge, Tennessee, U.S.A.

Defosse, G. E., and M. Bertiller. 1998. NPP Grassland: Media Luna, Argentina, 1981-1983. Available on-line [http://www.daac.ornl.gov/] from Oak Ridge National Laboratory Distributed Active Archive Center, Oak Ridge, Tennessee, U.S.A

Garcia-Moya, E. 1996. NPP Grassland: Montecillo, Mexico, 1984-1994. Available on-line [http://www.daac.ornl.gov/] from Oak Ridge National Laboratory Distributed Active Archive Center, Oak Ridge, Tennessee, U.S.A.

Gilmanov, T. G. 1996. NPP Grassland: Khomutov, Ukraine, 1948-1970. Available on-line [http://www.daac.ornl.gov/] from Oak Ridge National Laboratory Distributed Active Archive Center, Oak Ridge, Tennessee, U.S.A.

Gilmanov, T. G. 1996. NPP Grassland: Kursk, Russia, 1954-1983. Available on-line [http://www.daac.ornl.gov/] from Oak Ridge National Laboratory Distributed Active Archive Center, Oak Ridge, Tennessee, U.S.A.

Gilmanov, T. G. 1996. NPP Grassland: Otradnoe, Russia, 1969-1973. Available on-line [http://www.daac.ornl.gov/] from Oak Ridge National Laboratory Distributed Active Archive Center, Oak Ridge, Tennessee, U.S.A.

Gilmanov, T. G. 1996. NPP Grassland: Shortandy, Kazakhstan, 1975-1980. Available on-line [http://www.daac.ornl.gov/] from Oak Ridge National Laboratory Distributed Active Archive Center, Oak Ridge, Tennessee, U.S.A.

Gilmanov, T. G. 1996. NPP Grassland: Tuva, Russia, 1978-1985. Available on-line [http://www.daac.ornl.gov/] from Oak Ridge National Laboratory Distributed Active Archive Center, Oak Ridge, Tennessee, U.S.A.

Gilmanov, T. G. 1997. NPP Grassland: Dzhanybek, Kazakhstan, 1955-1989. Available on-line [http://www.daac.ornl.gov/] from Oak Ridge National Laboratory Distributed Active Archive Center, Oak Ridge, Tennessee, U.S.A.

Gilmanov, T. G. 1998. NPP Grassland: Badkhyz, Turkmenistan, 1948-1982. Available on-line [http://www.daac.ornl.gov/] from Oak Ridge National Laboratory Distributed Active Archive Center, Oak Ridge, Tennessee, U.S.A.

Hopkins, B. 1997. NPP Grassland: Olokemeji, Nigeria, 1956-1964. Available on-line [http://www.daac.ornl.gov/] from Oak Ridge National Laboratory Distributed Active Archive Center, Oak Ridge, Tennessee, U.S.A. 
Hulett, G. K., and G. W. Tomanek. 1998. NPP Grassland: Hays, U.S.A., 1970. Available on-line [http://www.daac.ornl.gov/] from Oak Ridge National Laboratory Distributed Active Archive Center, Oak Ridge, Tennessee, U.S.A.

Kamnalrut, A. 1996. NPP Grassland: Klong Hoi Khong, Thailand, 1984-1990. Available on-line [http://www.daac.ornl.gov/] from Oak Ridge National Laboratory Distributed Active Archive Center, Oak Ridge, Tennessee, U.S.A.

Kinyamario, J. I. 1996. NPP Grassland: Nairobi, Kenya, 1984-1994. Available on-line [http://www.daac.ornl.gov/] from Oak Ridge National Laboratory Distributed Active Archive Center, Oak Ridge, Tennessee, U.S.A.

Knapp, A. K., and D. Ojima. 1996. NPP Grassland: Konza Prairie, U.S.A., 1984-1990. Available on-line [http://www.daac.ornl.gov/] from Oak Ridge National Laboratory Distributed Active Archive Center, Oak Ridge, Tennessee, U.S.A.

Menaut, J. C. 1996. NPP Grassland: Lamto, Ivory Coast, 1965-1987. Available on-line [http://www.daac.ornl.gov/] from Oak Ridge National Laboratory Distributed Active Archive Center, Oak Ridge, Tennessee, U.S.A.

Pandey, C. B., and J. S. Singh. 1997. NPP Grassland: Vindhyan, India, 1986-1989. Available online [http://www.daac.ornl.gov/] from Oak Ridge National Laboratory Distributed Active Archive Center, Oak Ridge, Tennessee, U.S.A.

Pieper, R. D. 1998. NPP Grassland: Jornada, U.S.A., 1970-1972. Available on-line [http://www.daac.ornl.gov/] from Oak Ridge National Laboratory Distributed Active Archive Center, Oak Ridge, Tennessee, U.S.A.

Risser, P. G. 1998. NPP Grassland: Osage, U.S.A., 1970-1972. Available on-line [http://www.daac.ornl.gov/] from Oak Ridge National Laboratory Distributed Active Archive Center, Oak Ridge, Tennessee, U.S.A.

Sala, O. E. 2001. NPP Grassland: Rio Mayo, Argentina, 1983-1989. Available on-line [http://www.daac.ornl.gov/] from Oak Ridge National Laboratory Distributed Active Archive Center, Oak Ridge, Tennessee, U.S.A.

San Jose, J., and R. A. Montes. 1998. NPP Grassland: Calabozo, Venezuela, 1969-1987. Available on-line [http://www.daac.ornl.gov/] from Oak Ridge National Laboratory Distributed Active Archive Center, Oak Ridge, Tennessee, U.S.A.

Scholes, R. J. 1997. NPP Grassland: Nylsvley, South Africa, 1974-1989. Available on-line [http://www.daac.ornl.gov/] from Oak Ridge National Laboratory Distributed Active Archive Center, Oak Ridge, Tennessee, U.S.A.

Scholes, R. J. 1998. NPP Grassland: Towoomba, South Africa, 1949-1990. Available on-line [http://www.daac.ornl.gov/] from Oak Ridge National Laboratory Distributed Active Archive Center, Oak Ridge, Tennessee, U.S.A. 
Singh, J. S., and P. S. Yadava. 1997. NPP Grassland: Kurukshetra, India, 1970-1971. Available on-line [http://www.daac.ornl.gov/] from Oak Ridge National Laboratory Distributed Active Archive Center, Oak Ridge, Tennessee, U.S.A.

Togtohyn, C., and D. Ojima. 1996. NPP Grassland: Tumentsogt, Mongolia, 1982-1990. Available on-line [http://www.daac.ornl.gov/] from Oak Ridge National Laboratory Distributed Active Archive Center, Oak Ridge, Tennessee, U.S.A.

Uresk, D., P. L. Sims, and J. L. Dodd. 1996. NPP Grassland: Central Plains Experimental Range (SGS), U.S.A., 1970-1975. Available on-line [http://www.daac.ornl.gov/] from Oak Ridge National Laboratory Distributed Active Archive Center, Oak Ridge, Tennessee, U.S.A.

Wallentinus, H. G., and G. Tyler. 1997. NPP Grassland: Tullgarnsnaset, Sweden, 1968-1969. Available on-line [http://www.daac.ornl.gov/] from Oak Ridge National Laboratory Distributed Active Archive Center, Oak Ridge, Tennessee, U.S.A.

Weaver, T., and D. D. Collins. 1998. NPP Grassland: Bridger, U.S.A., 1970-1973. Available online [http://www.daac.ornl.gov/] from Oak Ridge National Laboratory Distributed Active Archive Center Oak Ridge, Tennessee, U.S.A.

Whitman, W., and W. K. Lauenroth. 1998. NPP Grassland: Dickinson, U.S.A., 1970. Available on-line [http://www.daac.ornl.gov/] from Oak Ridge National Laboratory Distributed Active Archive Center, Oak Ridge, Tennessee, U.S.A.

Williamson, P., and J. Pitman. 1998. NPP Grassland: Beacon Hill, U.K., 1972-1973. Available on-line [http://www.daac.ornl.gov/] from Oak Ridge National Laboratory Distributed Active Archive Center, Oak Ridge, Tennessee, U.S.A.

Xiao, X., and D. Ojima. 1996. NPP Grassland: Xilingol, China, 1980-1989. Available on-line [http://www.daac.ornl.gov/] from Oak Ridge National Laboratory Distributed Active Archive Center, Oak Ridge, Tennessee, U.S.A.

Xiao, X., and D. Ojima. 1999. NPP Grassland: Tumugi, China, 1981-1990. Available on-line [http://www.daac.ornl.gov/] from Oak Ridge National Laboratory Distributed Active Archive Center, Oak Ridge, Tennessee, U.S.A.

\section{Temperate Forest}

Waring, R. H., B. Law, and B. Bond. 1999. NPP Temperate Forest: OTTER Project Sites, Oregon, U.S.A., 1989-1991. Available on-line [http://www.daac.ornl.gov/] from Oak Ridge National Laboratory Distributed Active Archive Center, Oak Ridge, Tennessee, U.S.A.

\section{Tropical Forest}

Clark, D. A. 1998. NPP Tropical Forest: La Selva, Costa Rica, 1969-1985. Available on-line [http://www.daac.ornl.gov/] from Oak Ridge National Laboratory Distributed Active Archive Center, Oak Ridge, Tennessee, U.S.A.

Condit, R., D. M. Windsor, and S. P. Hubbell. 1996. NPP Tropical Forest: Barro Colorado, Panama, 1969-1990. Available on-line [http://www.daac.ornl.gov/] from Oak Ridge National Laboratory Distributed Active Archive Center, Oak Ridge, Tennessee, U.S.A. 
Edwards, P. J., and P. J. Grubb. 1999. NPP Tropical Forest: Marafunga, Papua New Guinea, 1970-1971. Available on-line [http://www.daac.ornl.gov/] from Oak Ridge National Laboratory Distributed Active Archive Center, Oak Ridge, Tennessee, U.S.A.

Folster, H. 1999. NPP Tropical Forest: Magdalena Valley, Colombia, 1970-1971. Available online [http://www.daac.ornl.gov/] from Oak Ridge National Laboratory Distributed Active Archive Center, Oak Ridge, Tennessee, U.S.A.

Golley, F. B. 1998. NPP Tropical Forest: Darien, Panama, 1967-1968. Available on-line [http://www.daac.ornl.gov/] from Oak Ridge National Laboratory Distributed Active Archive Center, Oak Ridge, Tennessee, U.S.A.

Grimm, U., and H. W. Fassbender. 1999. NPP Tropical Forest: San Eusebio, Venezuela, 19701971. Available on-line [http://www.daac.ornl.gov/] from Oak Ridge National Laboratory Distributed Active Archive Center, Oak Ridge, Tennessee, U.S.A.

Jordan, C. F., E. Cuevas, and E. Medina. 1999. NPP Tropical Forest: San Carlos de Rio Negro, Venezuela, 1975-1984. Available on-line [http://www.daac.ornl.gov/] from Oak Ridge National Laboratory Distributed Active Archive Center, Oak Ridge, Tennessee, U.S.A.

Kira, T. 1998. NPP Tropical Forest: Khao Chong, Thailand, 1962-1965. Available on-line [http://www.daac.ornl.gov/] from Oak Ridge National Laboratory Distributed Active Archive Center, Oak Ridge, Tennessee, U.S.A.

Kira, T., N. Manokaran, and S. Appanah. 1998. NPP Tropical Forest: Pasoh, Malaysia, 19711973. Available on-line [http://www.daac.ornl.gov/] from Oak Ridge National Laboratory Distributed Active Archive Center, Oak Ridge, Tennessee, U.S.A.

Lugo, A. E., F. Scatena, and C. F. Jordan. 1999. NPP Tropical Forest: Luquillo, Puerto Rico, 1963-1994. Available on-line [http://www.daac.ornl.gov/] from Oak Ridge National Laboratory Distributed Active Archive Center, Oak Ridge, Tennessee, U.S.A.

Maass, M., and A. Martínez-Yrizar. 2001. NPP Tropical Forest: Chamela, Mexico, 1982-1995. Available on-line [http://www.daac.ornl.gov/] from Oak Ridge National Laboratory Distributed Active Archive Center, Oak Ridge, Tennessee, U.S.A.

Nye, P. H., and D. J. Greenland. 1998. NPP Tropical Forest: Kade, Ghana, 1957-1972. Available on-line [http://www.daac.ornl.gov/] from Oak Ridge National Laboratory Distributed Active Archive Center, Oak Ridge, Tennessee, U.S.A.

Piedade, M. T. F., and W. J. Junk. 2001. NPP Tropical Forest: Manaus, Brazil, 1963-1990. Available on-line [http://www.daac.ornl.gov/] from Oak Ridge National Laboratory Distributed Active Archive Center, Oak Ridge, Tennessee, U.S.A.

Proctor, J. 1999. NPP Tropical Forest: Gunung Mulu, Malaysia, 1977-1978. Available on-line [http://www.daac.ornl.gov/] from Oak Ridge National Laboratory Distributed Active Archive Center, Oak Ridge, Tennessee, U.S.A. 
Stocker, G. C. 2001. NPP Tropical Forest: Atherton, Australia, 1974-1985. Available on-line [http://www.daac.ornl.gov/] from Oak Ridge National Laboratory Distributed Active Archive Center, Oak Ridge, Tennessee, U.S.A.

Tanner, E. V. J., and P. J. Grubb. 1999. NPP Tropical Forest: John Crow Ridge, Jamaica, 19741978. Available on-line [http://www.daac.ornl.gov/] from Oak Ridge National Laboratory Distributed Active Archive Center, Oak Ridge, Tennessee, U.S.A.

Weaver, P. L. 1999. NPP Tropical Forest: Cinnamon Bay, U.S. Virgin Islands, 1982-1993. Available on-line [http://www.daac.ornl.gov/] from Oak Ridge National Laboratory Distributed Active Archive Center, Oak Ridge, Tennessee, U.S.A.

\section{Boreal Forest}

Comeau, P. G., and J. P. Kimmins. 1999. NPP Boreal Forest: Canal Flats, Canada, 1984. Available on-line [http://www.daac.ornl.gov/] from Oak Ridge National Laboratory Distributed Active Archive Center, Oak Ridge, Tennessee, U.S.A.

Hall, F. G. 1997. NPP Boreal Forest: Superior National Forest, U.S.A., 1983-1984. Available online [http://www.daac.ornl.gov/] from Oak Ridge National Laboratory Distributed Active Archive Center, Oak Ridge, Tennessee, U.S.A.

Havas, P. 1999. NPP Boreal Forest: Kuusamo, Finland, 1967-1971. Available on-line [http://www.daac.ornl.gov/] from Oak Ridge National Laboratory Distributed Active Archive Center, Oak Ridge, Tennessee, U.S.A.

Krankina, O. N. 1999. NPP Boreal Forest: Siberian Scots Pine Forests, Russia, 1968-1974. Available on-line [http://www.daac.ornl.gov/] from Oak Ridge National Laboratory Distributed Active Archive Center, Oak Ridge, Tennessee, U.S.A.

Linder, S. 1998. NPP Boreal Forest: Flakaliden, Sweden, 1986-1996. Available on-line [http://www.daac.ornl.gov/] from Oak Ridge National Laboratory Distributed Active Archive Center, Oak Ridge, Tennessee, U.S.A.

Linder, S., and G. I. Agren. 1998. NPP Boreal Forest: Jadraas, Sweden, 1973-1980. Available on-line [http://www.daac.ornl.gov/] from Oak Ridge National Laboratory Distributed Active Archive Center, Oak Ridge, Tennessee, U.S.A.

Morrison, I. K., and N. W. Foster. 2001. NPP Boreal Forest: Mississagi, Canada, 1970-1973. Available on-line [http://www.daac.ornl.gov/] from Oak Ridge National Laboratory Distributed Active Archive Center, Oak Ridge, Tennessee, U.S.A.

Rencz, A. N., and A. N. D. Auclair. 2001. NPP Boreal Forest: Schefferville, Canada, 1974. Available on-line [http://www.daac.ornl.gov/] from Oak Ridge National Laboratory Distributed Active Archive Center, Oak Ridge, Tennessee, U.S.A.

\section{ORNL Collection of Multi-site and Multi-biome Data Sets}

Clark, D. A. 1998. NPP Tropical Forest: La Selva, Costa Rica, 1969-1985. Available on-line [http://www.daac.ornl.gov/] from Oak Ridge National Laboratory Distributed Active Archive Center, Oak Ridge, Tennessee, U.S.A. 
Comeau, P. G., and J. P. Kimmins. 1999. NPP Boreal Forest: Canal Flats, Canada, 1984. Available on-line [http://www.daac.ornl.gov/] from Oak Ridge National Laboratory Distributed Active Archive Center, Oak Ridge, Tennessee, U.S.A.

DeAngelis, D. L., R. H. Gardner, and H. H. Shugart. 1997. NPP Multi-Biome: Global IBP Woodlands Data, 1955-1975. Available on-line [http://www.daac.ornl.gov/] from Oak Ridge National Laboratory Distributed Active Archive Center, Oak Ridge, Tennessee, U.S.A.

Denissenko, E. A., V. Brovkin, and W. Cramer. 2001. NPP Multi-Biome: PIK Data for Northern Eurasia, 1940-1988 (Based on Bazilevich). Available on-line [http://www.daac.ornl.gov/] from Oak Ridge National Laboratory Distributed Active Archive Center, Oak Ridge, Tennessee, U.S.A.

Esser, G. 1998. NPP Multi-Biome: Global Osnabruck Data, 1937-1981. Available on-line [http://www.daac.ornl.gov/] from Oak Ridge National Laboratory Distributed Active Archive Center, Oak Ridge, Tennessee, U.S.A.

Hall, F. G. 1997. NPP Boreal Forest: Superior National Forest, U.S.A., 1983-1984. Available online [http://www.daac.ornl.gov/] from Oak Ridge National Laboratory Distributed Active Archive Center, Oak Ridge, Tennessee, U.S.A.

Kicklighter, D. W. 1999. NPP Multi-Biome: TEM Calibration Data, 1992. Available on-line [http://www.daac.ornl.gov/] from Oak Ridge National Laboratory Distributed Active Archive Center, Oak Ridge, Tennessee, U.S.A.

Krankina, O. N. 1999. NPP Boreal Forest: Siberian Scots Pine Forests, Russia, 1968-1974. Available on-line [http://www.daac.ornl.gov/] from Oak Ridge National Laboratory Distributed Active Archive Center, Oak Ridge, Tennessee, U.S.A.

Linder, S., and G. I. Agren. 1998. NPP Boreal Forest: Jadraas, Sweden, 1973-1980. Available on-line [http://www.daac.ornl.gov/] from Oak Ridge National Laboratory Distributed Active Archive Center, Oak Ridge, Tennessee, U.S.A.

Ni, J., X. S. Zhang, and J. M. O. Scurlock. 2001. NPP Multi-Biome: Chinese Forests Data, 19891994. Available on-line [http://www.daac.ornl.gov/] from Oak Ridge National Laboratory Distributed Active Archive Center, Oak Ridge, Tennessee, U.S.A.

Waring, R. H., B. Law, and B. Bond. 1999. NPP Temperate Forest: OTTER Project Sites, Oregon, U.S.A., 1989-1991. Available on-line [http://www.daac.ornl.gov/] from Oak Ridge National Laboratory Distributed Active Archive Center, Oak Ridge, Tennessee, U.S.A.

\section{UMD Collection of Gridded Cells}

Prince, S. D., J. Haskett, M. Steininger, H. Strand, and R. Wright. 2001. NPP Cropland: Gridded Data for the Central U.S.A., 1982-1996. Available on-line [http://www.daac.ornl.gov/] from the Oak Ridge National Laboratory Distributed Active Archive Center, Oak Ridge, Tennessee, U.S.A. 
Zheng, D. L., S. D. Prince, and R. Wright. 2001. NPP Multi-Biome: Gridded Data for Selected Regions Worldwide, 1989-2001. Available on-line [http://www.daac.ornl.gov/] from the Oak Ridge National Laboratory Distributed Active Archive Center, Oak Ridge, Tennessee, U.S.A.

\section{NCEAS Published NPP Data Sets}

Clark, D. A., S. Brown, D. W. Kicklighter, J. Q. Chambers, J. R. Thomlinson, J. Ni, and E. A. Holland. 2001. NPP Tropical Forest: Consistent Worldwide Data, 1967-1999. Available on-line [http://www.daac.ornl.gov/] from the Oak Ridge National Laboratory Distributed Active Archive Center, Oak Ridge, Tennessee, U.S.A.

Gill, R. A., R. H. Kelly, W. J. Parton, K. A. Day, R. B. Jackson, J. A. Morgan, J. M. O. Scurlock, L. L. Tieszen, J. V. Castle, D. S. Ojima, and X. S. Zhang. 2001. NPP Grassland: Consistent Worldwide Data, 1954-1990. Available on-line [http://www.daac.ornl.gov/] from the Oak Ridge National Laboratory Distributed Active Archive Center, Oak Ridge, Tennessee, U.S.A.

Gower, S. T., O. Krankina, R. J. Olson, M. Apps, S. Linder, and C. Wang. 2001. NPP Boreal Forest: Consistent Worldwide Data, 1977-1994. Available on-line [http://www.daac.ornl.gov/] from the Oak Ridge National Laboratory Distributed Active Archive Center, Oak Ridge, Tennessee, U.S.A.

\section{GPPDI Data Set}

Olson, R. J., J. M. O. Scurlock, S. D. Prince, D. L. Zheng, and K. R. Johnson (eds.). 2001a. NPP Multi-Biome: Global Primary Production Data Initiative Products. Available on-line [http://www.daac.ornl.gov/] from the Oak Ridge National Laboratory Distributed Active Archive Center, Oak Ridge, Tennessee, U.S.A.

\section{EMDI Data Set}

Olson, R. J., J. M. O. Scurlock, S. D. Prince, D. L. Zheng, and K. R. Johnson (eds.). 2001b. NPP Multi-Biome: Data and Drivers for Ecosystem Model-Data Intercomparison. Available on-line [http://www.daac.ornl.gov/] from the Oak Ridge National Laboratory Distributed Active Archive Center, Oak Ridge, Tennessee, U.S.A.

\subsection{LITERATURE CITED}

Agren, G. I., B. Axelsson, J. G. K. Flower-Ellis, S. Linder, H. Persson, H. Staaf, and E. Troeng. 1980. Annual carbon budget for a young Scots pine. pp. 307-13. In T. Persson (ed.), Structure and function of northern coniferous forests - an ecosystem study. Ecol. Bull., Vol. 32, Stockholm.

Barrett, D. J. 2001. Steady state net primary productivity, carbon stocks and mean residence time of carbon in the Australian terrestrial biosphere. Global Biogeochemical Cycles (submitted).

Batjes, N. H. (ed.). 1995. A homogenized soil data file for global environmental research: A subset of FAO, ISRIC and NRCS profiles (Version 1.0). Working Paper and Preprint 95/10b, International Soil Reference and Information Centre, Wageningen, The Netherlands. 
Birdsey, R. A., and H. T. Schreuder. 1992. An overview of forest inventory and analysis estimation procedures in the Eastern United States--with an emphasis on the components of change. Gen. Tech. Report, U.S. Department of Agriculture, Forest Service, Rocky Mountain Forest and Range Experiment, Ft. Collins, Colo., RM-214.

Brown, S. L., P. Schroeder, and J. S. Kern. 1999. Spatial distribution of biomass in forests of the eastern USA. For. Ecol. Manage. 123:81-90.

Buzykin, A. I. 1978. Productivity of Pine Forests. Nauka Publishers, Moscow.

Cairns, M. A., S. L. Brown, E. H. Helmer, and G. A. Baumgardner. 1997. Root biomass allocation in the world's upland forests. Oecologia 111:1-11.

Canadell, J. G., H. A. Mooney, D. D. Baldocchi, J. A. Berry, J. R. Ehleringer, C. B. Field, S. T. Gower, D. Y. Hollinger, J. E. Hunt, R. B. Jackson, S. W. Running, G. R. Shaver, W. Steffen, S. E. Trumbore, R. Valentini, and B. Y. Bond. 2000. Carbon metabolism of the terrestrial biosphere: A multi-technique approach for improved understanding. Ecosystems 3:115-30.

Cannell, M. G. R. 1982. World Forest Biomass and Primary Production Data. Academic Press, London.

Carter, A. J., and R. J. Scholes. 2000. Soil Data v2.0: Generating a Global Database of Soil Properties. Environmentek CSIR, South Africa.

Clark, D. A., S. Brown, D. W. Kicklighter, J. Q. Chambers, J. R. Thomlinson, J. Ni, and E. A. Holland. 2001. NPP in tropical forests: An evaluation and synthesis of the existing field data. Ecol. Appl. 11(2):371-84.

Clark, D. A., S. Brown, D. W. Kicklighter, J. Q. Chambers, J. R. Thomlinson, J. Ni, and E. A. Holland. 2001. Measuring net primary production in forests: Concepts and field methods. Ecol. Appl. 11(2):356-70.

Cohen, W. B., T. A. Spies, and M. Fiorella. 1995. Estimating the age and structure of forests in a multi-ownership landscape of western Oregon, USA. Int. J. Remote Sens. 16:721-46.

Comeau, P. G., and J. P. Kimmins. 1989. Aboveground and below ground biomass and production of lodgepole pine on sites with differing soil-moisture regimes. Can. J. For. Res. 19:447-54.

Cramer, W., B. Moore III, and D. Sahagian. 1996. Data needs for modelling global biosphere carbon fluxes--lessons from a comparison of models. IGBP Newsletter 1996(27):13-15.

Cramer, W., D. W. Kicklighter, A. Fischer, B. Moore III, G. Churkina, A. Ruimy, and A. Schloss. 1999. Comparing global models of terrestrial net primary productivity (NPP): Overview and key results. Global Chg. Biol. 5 (Suppl. 1):1-15.

Cramer, W., J. M. O. Scrulock, R. J. Olson, W. J. Parton, and Stephen D. Prince. 1999. Net Primary Productivity: From Sparse Field Observations to a Consistent Global Data set for Terrestrial Models. Book Chapter. 
Day, K. A., M. R. McCaskill, and G. M. McKeon. 1997. A review of pasture production data in Queensland. In K. A. Day, G. M. McKeon, and J. O. Carter (eds.), Evaluating the Risks of Pasture and Land Degradation in Native Pastures in Queensland. Final report for Rural Industries Research and Development Corporation Project DAQ-124A, February.

DeAngelis, D. L., R. H. Gardner, and H. H. Shugart. 1981. Productivity of forest ecosystems studied during the IBP: The woodlands data set. pp. 567-672. In D. E. Reichle (ed.), Dynamics of Forest Ecosystems. IBP 23. Cambridge University Press, Cambridge, United Kingdom.

Diallo, O., A. Diouf, N. P. Hanan, A. Naliaye, and Y. Prevost. 1991. AVHRR monitoring of savanna primary production in Senegal, West Africa: 1987-1988. Int. J. Remote Sens. 12:1259279.

Esser, G. 1992. Implications of climate change for production and decomposition in grasslands and coniferous forests. Ecol. Appl. 2:47-54.

Esser, G., and M. Lautenschlager. 1994. Estimating the change of carbon in the terrestrial biosphere from 18000 BP to present using a carbon cycle model. Environ. Pollut. 83:4553.

Esser, G., H. F. H. Lieth, J. M. O. Scurlock, and R. J. Olson. 1997. Worldwide estimates and bibliography of net primary productivity derived from pre-1982 publications. ORNL/TM-13485. Oak Ridge National Laboratory.

Etheridge, D. M., L. P. Steele, R. L. Langenfelds, R. J. Francey, J. M. Barnola, and V.I. Morgan. 1998. Historical CO2 records from the Law Dome DE08, DE08-2, and DSS ice cores. In Trends: A Compendium of Data on Global Change. Carbon Dioxide Information Analysis Center, Oak Ridge National Laboratory.

Fan, S., M. Gloor, J. Mahlman, S. Pacala, J. Sarmiento, T. Takahashi, and P. Tans. 1998. A large terrestrial carbon sink in North America implied by atmospheric and oceanic carbon dioxide data and models. Science 282:442-46.

FAO. 1995. The digital soil map of the world. Ver. 3.5. U.N. Food and Agriculture Organization, Rome.

Forestry Ministry of China. 1994. Statistics on forest resources of China (1989-1993). Forestry Publisher, Beijing, China.

Gabeev, V. N. 1990. Ecology and Productivity of Pine Forests. Nauka Publishers, Novosibirsk, Russia.

Gholz, H. L., A. Campbell, K. Cromack Jr., A. T. Brown, and G. M. Hawk. 1985. Early vegetation recovery and element cycles on a clear-cut watershed in western Oregon. Can. J. For. Res. 15:400-09.

Gill, R. A., R. H. Kelly, W. J. Parton, K. A. Day, R. B. Jackson, J. A. Morgan, J. M. O. Scurlock, L. L. Tieszen, J. Vande Castle, D. S. Ojima, and X. S. Zhang. 2001. Using simple environmental variables to estimate below ground productivity in grasslands. Global Ecology and Biogeography (in press). 
Global Soil Data Task. 2000. Global Soil Data Products CD-ROM (IGBP-DIS). International Geosphere-Biosphere Programme - Data and Information Services. Available online at [http://www.daac.ornl.gov/] from the ORNL Distributed Active Archive Center, Oak Ridge National Laboratory.

Goetz, S., O. Krankina, L. Tieszen, J. Jenkins, B. Wylie, T. Maiersperger, and W. Cohen. 2001. Net primary production at the landscape scale: Spatial extrapolation of field measurements using areal stratification (in review).

Goetz, S. J., and S. D. Price. 1996. Remote sensing of net primary production in boreal forest stands. Agric. For. Meteorol. 78.

Gower, S. T., O. Krankina, R. J. Olson, M. Apps, S. Linder, and C. K. Wang. 2000. Net primary production and carbon allocation patterns of boreal forest ecosystems. Ecological Applications (in press).

Greenland, D. J., and J. M. L. Kowal. 1960. Nutrient content of the tropical moist forest of Ghana. Plant Soil 12:154-174.

Grier, C. C., and R. S. Logan. 1977. Old-growth Pseudotsuga menziesii communities of a western Oregon watershed: Biomass distribution and production budgets. Ecol. Monogr. 47:373-400.

Hall, F. G., K. F. Huemmrich, D. E. Strebel, S. J. Goetz, J. E. Nickeson, and K. D. Woods. 1992. Biophysical, Morphological, Canopy Optical Property, and Productivity Data from the Superior National Forest. NASA Technical Memorandum 104568, National Aeronautics and Space Administration, Washington, D.C.

Hame, T., A. Salli, K. Andersson, and A. Lohi. 1997. A new methodology for the estimation of biomass of conifer-dominated boreal forest using NOAA AVHRR data. Int. J. Remote Sens. 18:3211-243.

Hansen, A. J., J. J. Rotella, M. P. V. Kraska, and D. Brown. 2000a. Spatial patterns of primary productivity in the Greater Yellowstone ecosystem. Landscape Ecol. 15:505-22.

Hansen, M. C., R. S. Defries, J. R. G. Townshend, and R. Sohlberg. 2000b. Global land cover classification at $1 \mathrm{~km}$ spatial resolution using a classification tree approach. Int. J. Remote Sens. 21:1331-364.

Hansen, M. H., T. Frieswyk, J. F. Glover, and J. F. Kelly. 1992. The Eastwide Forest Inventory Data Base: Users Manual. USDA Forest Service. Data available from: http://www.srsfia.usfs.msstate.edu/tables.htm.

Hanson, P. J., D. E. Todd, and J. S. Amthor. 2001. A six-year study of sapling and large tree growth and mortality responses to natural and induced variability in precipitation and throughfall. Tree Physiology (in press).

Hibbard, K. A., and D. Sahagian. 1998. Net Primary Productivity Model Intercomparison Activity. IGBP/GAIM Report \#5. International-Geosphere Program/Global Analysis, Interpretation, and Modelling. 
Hume, M. 1999. 'g55wld0098.dat' (Ver. 1.0), constructed and supplied by Dr Mike Hulme at the Climatic Research Unit, University of East Anglia, Norwich, United Kingdom. This work has been supported by the United Kingdom Department of the Environment, Transport, and the Regions (Contract EPG 1/1/48).

James, M. E., and S. N. V. Kalluri. 1994. The Pathfinder AHRR land data set. An improved coarse resolution data set for terrestrial monitoring. Int. J. Remote Sens. 15:3347-364.

Jenkins, J. C., R. A. Birdsey, and Y. Pan. 2001. Potential biomass and NPP estimation for the mid-Atlantic region (USA) using forest inventory data. Ecol. Appl. 11(4):1174-193.

Jiang, H., M. J. Apps, Y. Zhang, C. Peng, and P. M. Woodard. 1999. Modelling the spatial pattern of net primary productivity in Chinese forests. Ecol. Modell. 122:275-88.

Joyce, L. A., D. E. Chalk, and A. Vigil. 1986. Range forage database for 20 Great Plains, southern, and western states. General Techical Report RM-133, U.S. Department of Agriculture, U.S. Forest Service, Ft. Collins, Colo.

Keeling, C. D., and T. P. Whorf. 2001. Atmospheric CO2 records from sites in the SIO air sampling network. In Trends: A Compendium of Data on Global Change. Carbon Dioxide Information Analysis Center, Oak Ridge National Laboratory.

Krankina, O. N., S. Brown, J. C. Jenkins, D. Kicklighter, M. J. Apps, and R. J. Olson. 2001. Use of forest inventory data for estimating NPP. Ecological Applications (in review).

Lauenroth, W. K., and O. E. Sala. 1992. Long-term forage production of North American shortgrass steppe. Ecol. Appl. 2:397-403.

Leemans, R., and W. Cramer. 1991. The IIASA database for mean monthly values of temperature, precipitation, and cloudiness of a global terrestrial grid. International Institute for Applied Systems Analysis. RR91-18.

Leith, H. 1975. Modeling the primary productivity of the world. pp. 238-63. In H. Lieth and R. H. Whittaker (eds.), Primary Productivity of the Biosphere. Springer-Verlag, New York.

Leith, H., and R. H. Whitaker (eds.). 1975. Primary Productivity of the Biosphere. SpringerVerlag, Berlin.

Lonsdale, W. M. 1988. Predicting the amount of litter fall in forests of the world. Annu. Bot. 61:319-24.

Luo, T. X. 1996. Patterns of biological production and its mathematical models for main forest types of China. Ph.D. dissertation. Committee of Synthesis Investigation of Natural Resources. Chinese Academy of Sciences, Beijing, China (in Chinese).

Lurin, B., W. Cramer, B. Moore, and I. Rasool. 1994. Global terrestrial net primary productivity first model intercomparison workshop. Global Change Newsletter (IGBP) 19:6-8.

McDade, L. A., K. S. Bawa, H. A. Hespenheide, and G. S. Hartshorn (eds.). 1994. La Selva: Ecology and Natural History of a Neotropical Rain Forest. University of Chicago Press. 
McGuire, A. D., J. M. Melillo, L. A. Joyce, D. W. Kicklighter, A. L. Grace, B. Moore III, and C. J. Vorosmarty. 1992. Interactions between carbon and nitrogen dynamics in estimating net primary productivity for potential vegetation in North America. Global Biogeochem. Cycles 6:101-24.

Means, J. E., H. A. Hansen, G. J. Koerper, P. B. Alaback, and M. W. Klopsch. 1994. Software for computing plant biomass-BIOPAK user guide. United States Department of Agriculture Forest Service, Pacific Northwest Research Station. General Technical Report PNW-GTR-340.

Portland, Oregon.

New, M. G., M. Hulme, and P. D. Jones. 2000b. Global Mean Monthly Climatology, 1901-1995. Available online at [http://www.daac.ornl.gov/] from the ORNL Distributed Active Archive Center, Oak Ridge National Laboratory.

New, M. G., M. Hulme, and P. D. Jones. 1999. Representing 20th century space-time climate variability. I: Development of a 1961-1990 mean monthly terrestrial climatology. J. Climate 12:829-56.

New, M. G., M. Hulme, and P. D. Jones. 2000a. Representing 20th century space-time climate variability. II: Development of 1901-1996 monthly grids of terrestrial surface climate. J. Climate 13:2217-238.

Ni, J., X. S. Zhang, and J. M. O. Scurlock. 2000. Synthesis and analysis of biomass and net primary productivity in Chinese forests. Annals of Forest Science (in press).

Pandey, C. B., and J. S. Singh. 1992. Rainfall and grazing effects on net primary production in a tropical savanna, India. Ecology 73:2007-021.

Prince, S. D., J. Haskett, M. Steininger, H. Strand, and R. Wright. 2001. Net primary production of U.S. midwest croplands from agricultural harvest yield data. Ecol. Appl. 11(4):1194-205.

Prince, S. D., R. J. Olson, G. Dedieu, G. Esser, and W. Cramer. 1995. Global Primary Production Data Initiative Project Description. IGBP-DIS Working Paper No. 12. International GeosphereBiosphere Program - Data and Information System, Toulouse.

Raich, J. W., and K. J. Nadelhoffer. 1989. Below ground carbon allocation in forest ecosystems: Global trends. Ecology 70:1346-354.

Raich, J. W., E. B. Rastetter, J. M. Mellillo, D. W. Kicklighter, P. A. Steudler, and B. J. Petterson. 1991. Potential net primary productivity in South America: Application of a global model. Ecol. Appl. 1:399-429.

Runyon, J., R. H. Waring, S. N. Goward, and J. M. Welles. 1994. Environmental limits on net primary production and light-use efficiency across the Oregon transect. Ecol. Appl. 4:226-37.

Sala, O. E., W. J. Parton, L. A. Joyce, and W. K. Lauenroth. 1988. Primary production of the central grassland region of the United States. Ecology 69:40-5.

Schimel, D. S., VEMAP Participants, and B. H. Braswell. 1997. Continental scale variability in ecosystem processes: Models, data, and the role of disturbance. Ecol. Monogr. 67:251-71. 
Scholes, R. J., D. Skole, and J. S. Ingram (eds.). 1995. A Global Database of Soil Properties: Proposal for Implementation. Report of the Global Soils Task Group, IGBP-DIS Working Paper \# 10, University of Paris.

Scurlock, J. M. O., W. Cramer, R. J. Olson, W. J. Parton, and S. D. Prince. 1999. Terrestrial NPP: Towards a consistent data set for global model evaluation. Ecol. Appl. 9(3):913-19.

Scurlock, J. M. O., and R. J. Olson. 2001. Terrestrial Net Primary Productivity: A Brief History and Worldwide Database. Environmental Reviews (accepted).

Scurlock, J. M. O., K. Johnston, and R. J. Olson. 2001. Estimating net primary productivity from grassland biomass dynamics measurements. Global Change Biology (accepted).

Sims, P. L., and J. S. Singh. 1978. The structure and function of ten western North American grasslands. III. Net primary production, turnover and efficiencies of energy capture and water use. J. Ecol. 66:573-97.

Singh and Yadava. 1974. Seasonal variation in composition, plant biomass and net primary productivity of a tropical grassland at Kurukshetra, India. Ecol. Monogr. 44:351-76.

Tieszen, L. L., B. C. Reed, and D. D. Dejong. 1997. NDVI, C3 and C4 production, and distributions in Great Plains grassland land cover classes. Ecol. Appl. 7:59-78.

Turner, D. P., G. J. Koerper, M. E. Hanmon, and J. J. Lee. 1995. A carbon budget for forests of the conterminous United States. Ecol. Appl. 5:421-36.

Turner, D. P., W. B. Cohen, and R. E. Kennedy. 2000. Alternative spatial resolutions and estimations of carbon flux over a managed forest landscape in Western Oregon. Landscape Ecol. $15: 441-52$.

Turner, J., and J. N. Long. 1975. Accumulation of organic matter in a series of Douglas-fir stands. Can. J. For. Res. 5:681-90.

Vogt, K. 1991. Carbon budgets of temperate forest ecosystems. Tree Physiol. 9:69-86.

Wharton, E. H., and D. M. Griffith. 1998. Estimating total forest biomass in Maine, 1995. Radnor, Pa. United States Department of Agriculture Forest Service, Northeast Forest Experiment Station.

Wharton, E. H., A. L. Alerich, and D. A. Drake. 1997. Estimating total forest biomass in New York, 1993. Radnor, Pa. United States Department of Agriculture Forest Service, Northeast Forest Experiment Station. Report No. Resource Bulletin NE-139.

Wu, Z. 1980. Chinese vegetation. Science Press, Beijing, China.

Zheng, D. L., and R. J. Alig. 1999. Changes in the non-federal land base involving forestry in Western Oregon, 1961-94. United States Department of Agriculture Forest Service, Pacific Northwest Research Station. PNW-RP-518. 
Zheng, D. L., S. D. Prince, and R. Wright. 2001a. Terrestrial net primary production estimates for 0.5 degree grid cells from field observations - a contribution to global biogeochemical modelling. Global Change Biology (in review).

Zheng, D. L., S. D. Prince, and T. Hame. 2001b. Estimating net primary production of coniferdominated boreal forests in Finland and Sweden at 1-km and 0.5 degree cells (in preparation).

Zobler, L. 1986. A world soil file for global climate modelling. NASA Technical Memorandum TM-87802. 
APPENDIX A

CONTRIBUTORS TO THE NPP DATABASE AND PARTICIPANTS IN THE EMDI WORKSHOP 
Appendix A

Contributors to the NPP database and participants in the EMDI Workshop

\begin{tabular}{lll}
\hline \multicolumn{1}{c}{ Last Name } & First Name & \multicolumn{1}{c}{ Institution } \\
\hline Aber & John & University of New Hampshire, U.S.A. \\
Braswell & Rob & University of New Hampshire, U.S.A. \\
Brovkin & Victor & Potsdam Institute for Climate Impact Research, Germany \\
Cramer & Wolfgang & Potsdam Institute for Climate Impact Research, Germany \\
Cushman & Bob & ORNL Carbon Dioxide Information and Analysis Center, \\
& & U.S.A. \\
Del Grossa & Steve & Colorado State University, U.S.A. \\
Feldkirchner & Drew & University of Wisconsin-Madison, U.S.A. \\
Field & Chris & Carnegie Institution, Stanford, U.S.A. \\
Foley & Jon & University of Wisconsin, U.S.A. \\
Friedlingston & Pierre & CNRS, France \\
Gower & Tom & University of Wisconsin-Madison, U.S.A. \\
Hibbard & Kathy & University of New Hampshire, U.S.A. \\
Jenkins & Jennifer & USDA Forest Service, U.S.A. \\
Ji & Jinjun & Institute of Atmospheric Physics, China \\
Johnson & Keri & Oak Ridge National Laboratory, U.S.A. \\
Kaduk & Jörg & Carnegie Institution, Stanford, U.S.A. \\
Kergoat & Laurent & CNRS, France \\
King & Tony & Oak Ridge National Laboratory, U.S.A. \\
Kucharik & Chris & University of Wisconsin, U.S.A. \\
Law & Beverly & Oregon State University, U.S.A. \\
Nemry & Bernard & University of Liege, Belgium \\
Ni & Jian & University of Beijing, China \\
Olson & Dick & Oak Ridge National Laboratory, U.S.A. \\
Parton & Bill & Colorado State University, U.S.A. \\
Post & Mac & Oak Ridge National Laboratory, U.S.A. \\
Prince & Steve & University of Maryland, U.S.A. \\
Scurlock & Jonathan & Oak Ridge National Laboratory, U.S.A. \\
Sitch & Stephen & Potsdam Institute for Climate Impact Research, Germany \\
Smith & Ben & Potsdam Institute for Climate Impact Research, Germany \\
Thornton & Peter & University of Montana, U.S.A. \\
Tieszen & Larry & USGS EROS Data Center, U.S.A. \\
Wright & Robb & University of Maryland, U.S.A. \\
Zheng & Daolan & University of Maryland, U.S.A. \\
\hline & &
\end{tabular}


APPENDIX B

CLASS C 0.5 ${ }^{\circ}$ GRID CELL DATA FORMAT AND PROCESSING NOTES 


\section{APPENDIX B: CLASS C $0.5^{\circ}$ GRID CELL DATA FORMAT AND PROCESSING NOTES}

NPP and driver data for EMDI II Class C cells were compiled by Daolan Zheng of the Geography Department at the University of Maryland (version dated October 4, 2000). Drivers includes elevation, biome, monthly climate (mean, min, and max temperature and total precipitation), NDVI, and soil texture (fraction sand, silt, and clay). The specific contents are described below, along with notes describing the processing performed by the University of Maryland. Specific questions on the Class C data can be addressed to Daolan Zheng, dzheng@geog.umd.edu, telephone (301) 314-2798, or Steven Prince, sp43@umail.umd.edu, telephone (301) 405-4062.

Table B.1. File layout, variables, and units of measure for the Class $\mathrm{C} 0.5^{\circ}$ grid cell measurements

\begin{tabular}{|c|c|c|}
\hline Variable & Units & Description \\
\hline Lat & Degrees & Latitude of $.5^{\circ}$ cell centroid \\
\hline Lon & Degrees & Longitude of $.5^{\circ}$ cell centroid \\
\hline Anpp & $\mathrm{gC} / \mathrm{m}^{2} / \mathrm{y}$ & Aboveground NPP reported in $\mathrm{gC} / \mathrm{m}^{2} / \mathrm{y}$ \\
\hline Totnpp & $\mathrm{gC} / \mathrm{m}^{2} / \mathrm{y}$ & Total NPP reported in $\mathrm{gC} / \mathrm{m}^{2} / \mathrm{y}$ \\
\hline Elev & Meters & Elevation in meter (http://www.ngdc.noaa.gov/seg/topo/globe.shtml) \\
\hline Ele_std & Meters & $\begin{array}{l}\text { Standard deviation of elevation in a } 0.5 \text { cell based on } 1-\mathrm{km} \text { data } \\
\text { (http://www.ngdc.noaa.gov/seg/topo/globe.shtml) }\end{array}$ \\
\hline Anu_avgT & ${ }^{\circ} \mathrm{C}$ & Annual mean air temperature $\left({ }^{\circ} \mathrm{C}\right), 1961-1990$, New et al. \\
\hline Jan_avgT & ${ }^{\circ} \mathrm{C}$ & Mean monthly air temperature $\left({ }^{\circ} \mathrm{C}\right)$ in January $1961-1990$ \\
\hline Jan_minT & ${ }^{\circ} \mathrm{C}$ & Minimum monthly air temperature $\left({ }^{\circ} \mathrm{C}\right)$ in January $1961-1990$ \\
\hline Jan_maxT & ${ }^{\circ} \mathrm{C}$ & Maximum monthly air temperature $\left({ }^{\circ} \mathrm{C}\right)$ in January $1961-1990$ \\
\hline \multicolumn{3}{|l|}{$\cdots$} \\
\hline$\cdots$ & & \\
\hline Dec_avgT & ${ }^{\circ} \mathrm{C}$ & Mean monthly arr temperature $\left({ }^{\circ} \mathrm{C}\right)$ in December $1961-1990$ \\
\hline Dec_minT & ${ }^{\circ} \mathrm{C}$ & Minimum monthly air temperature $\left({ }^{\circ} \mathrm{C}\right)$ in December $1961-1990$ \\
\hline Dec_maxT & ${ }^{\circ} \mathrm{C}$ & Maximum monthly air temperature $\left({ }^{\circ} \mathrm{C}\right)$ in December $1961-1990$ \\
\hline Anu_ppt & Millimeters & Annual mean total precipitation in millimeters, $1961-1990$, New et al. \\
\hline Jan_avgppt & Millimeters & Mean monthly total precipitation in millimeters in January $1961-1990$ \\
\hline Jan_minppt & Millimeters & $\begin{array}{l}\text { Minimum monthly total precipitation in millimeters in January 1961- } \\
1990\end{array}$ \\
\hline Jan_maxppt & Millimeters & $\begin{array}{l}\text { Maximum monthly total precipitation in millimeters in January 1961- } \\
1990\end{array}$ \\
\hline \multicolumn{3}{|l|}{$\cdots$} \\
\hline Dec avgppt & Millimeters & Mean monthly total precipitation in millimeters in December $1961-1990$ \\
\hline Dec_minppt & Millimeters & $\begin{array}{l}\text { Minimum monthly total precipitation in millimeters in December 1961- } \\
1990\end{array}$ \\
\hline Dec_maxppt & Millimeters & $\begin{array}{l}\text { Maximum monthly total precipitation in millimeters in December 1961- } \\
1990\end{array}$ \\
\hline Jan_ndvi & & $\begin{array}{l}\text { Monthly mean NDVI in January (August } 1981 \text { through July } 1994 \text { from } \\
\text { University of New Hampshire) }\end{array}$ \\
\hline \multicolumn{3}{|l|}{$\cdots$} \\
\hline Dec_ndvi & & $\begin{array}{l}\text { Monthly mean NDVI in December (August } 1981 \text { through July } 1994 \text { from } \\
\text { University of New Hampshire) }\end{array}$ \\
\hline
\end{tabular}


Table B.1 (continued)

\begin{tabular}{|c|c|c|}
\hline Variable & Units & Description \\
\hline Landcover & Code & $\begin{array}{l}\text { Landcover types at } 0.5^{\circ} \text { based on Hansen et al. } 2000 \mathrm{~b} \text {, University of } \\
\text { Maryland }\end{array}$ \\
\hline sand & $\%$ & Percentages of soil composition in sand, Zobler, 1986 \\
\hline silt & $\%$ & Percentages of soil composition in silt, Zobler, 1986 \\
\hline clay & $\%$ & Percentages of soil composition in clay, Zobler, 1986 \\
\hline Biome & & Biome types (see Table 4) \\
\hline Methods & & $\begin{array}{l}\text { Major methods used in developing NPP values: } \\
\text { FIA=Forest Inventory and Assessment; } \\
\text { RS=Remote sensing; } \\
\text { NASS=National Agricultural Statistics Service; } \\
\text { STATSGO=State Soil Geographic Data }\end{array}$ \\
\hline Year(s) & & Period from which the NPP was estimated (N/A = Not applied) \\
\hline Source & & Primary author for NPP values \\
\hline Type & & Data type (I/II, III, cell) \\
\hline Id & & Unique ID number for each record \\
\hline Flag & Code & $\begin{array}{l}\text { Outliers that outside of } \pm 2 \text { std of total NPP at biome level: } \\
\quad 1=\text { outside the low end; } \\
2=\text { outside the high end of the range. } \\
\text { The test was based on landcover type at the } 0.5 \text { cell after regrouping the } \\
13 \text { classes (Hansen et al. } 2000 \text { b) as follows: } \\
\text { forest }=1-6 ; \\
\text { savanna }=7 \\
\text { shrub }=8-9 ; \\
\text { grass }=10 \\
\text { crop }=11 ; \\
\text { desert }=12\end{array}$ \\
\hline
\end{tabular}

\section{Processing Notes}

1) Except for 14 cells (IDs 1921, 1922, 5001, 5002, 7001-7008, and 10001) and those provided by Barrett and Raich, for which NPP was expressed in units of $\mathrm{gC} / \mathrm{m}^{2} / \mathrm{y}$ (no conversion required), all other cells were provided in units of grams biomass and were converted to $\mathrm{gC} / \mathrm{m}^{2} / \mathrm{y}$ by multiplying by 0.475 for forest and 0.45 for grassland.

2) The total NPP values for cells with ID\# 8001-8100 (Sala) were calculated by TNPP $\left(\mathrm{gC} / \mathrm{m}^{2} / \mathrm{y}\right)=1.54 \mathrm{ANPP}+111.7$, derived from Parton's ANPP and TNPP, because only ANPP was provided for those cells.

3) Cells 1921 and 1922 have the same coordinates as 1919 and 1920 (all from Tieszen). However, the NPP data were derived from different methods. The NPP values $(1921,1922)$ were derived from land cover stratification and NPP values for all the other 920 cells of Tieszen were based on the STATSGO database to estimate mean potential aboveground production (ANPP) for map units related to soil surveys at each site (Tieszen et al. 1997).

4) For Prince data, the total NPP values for cells with ID\# 9001-9155 were for Midwest states in 1992, while the total NPP values for cells with ID\# 9156-9220 were the mean from 1982 through 1996 for the state of Iowa.

5) Methods used for developing NPP for the 62 cells based on Brown et al. (1999) are described in Zheng et al. (2001a) and summarized below:

- Brown's original data contain aboveground annual mean woody increment. 
- Leaf litter fall production was estimated based on latitude (Lonsdale 1988).

- Fine root production = leaf litter fall (Raich and Nadelhoffer 1989).

- Coarse root production $=22.5 \%$ of aboveground woody increment (Krankina et al. 2001); as a result, $\mathrm{ANPP}=\mathrm{a}+\mathrm{b}$ and $\mathrm{TNPP}=\mathrm{ANPP}+\mathrm{c}+\mathrm{d}$.

- Only those counties in Brown's study with forest cover $>=75 \%$ were used. Also, only the cells $(0.5 \times 0.5)$ that were fully covered with the selected counties whose NPP were calculated using area-weighted method were used.

6) Vegetation type for each cell was based on the 1-km gridded global land cover map of Hansen et al. (2000b), except for the cells from Raich (vegetation type provided).

7) The criteria used for selecting cells vary from one study to another. In other words, it is always a balance between the data quality and availability of NPP cell quantity. Details are shown below.

- There were a total of 25500.5 cells available in Australia. Only those cells in which the dominant land cover type covered $>90 \%$ of the total cell area were selected (resulted in 615).

- A total of 680.5 cells were available in Senegal, then $75 \%$ criteria was used (32 selected).

- For the study in Finland/Sweden, the cells selected must include a) location $<66.0 \mathrm{~N}$ (within conifer forest zoon), b) forest cover $>80 \%$ of the cell area, and c) evergreen needleleaf forest $>50 \%$ of the cell area (resulted in 82 ).

- For the study in South America, dominated type must be $>90 \%$ (1510 selected) of the cell area.

8) Outliers were flagged as outside the range of \pm 2 standard deviations of total NPP, grouped by landcover type. Similar (but not identical) results are reported by Zheng et al. (2001a). A summary table follows:

\begin{tabular}{ccccc}
\hline Type & $\begin{array}{c}\text { Mean } \\
\left(\mathrm{gC} / \mathrm{m}^{2} / \mathrm{y}\right)\end{array}$ & Standard error & Range & \# of cell \\
\hline Forest & 798 & 824 & $0-2446$ & 2057 \\
Savanna & 335 & 134 & $67-603$ & 469 \\
Shrub & 84 & 75 & $0-234$ & 826 \\
Grass & 204 & 61 & $82-326$ & 902 \\
Crop & 397 & 128 & $141-653$ & 835 \\
Desert & 83 & 116 & $0-315$ & 21 \\
Urban & 7 & & & \\
Water & 12 & & & \\
\hline
\end{tabular}

No outlier checks were done for those cells classified as urban and water. Values for forests present a problem because of inclusion of "woodlands," which cover some cells at high latitudes in Sweden and Finland with very low TNPP, together with many forest cells from the Amazon basin that have high potential TNPP.

9) The data set was evaluated by comparison with existing literature and the widely used Miami model.

10) A 13-year average NDVI was provided for EMDI II Class C cells based on an analysis of the relationships between 3-year and 13-year NDVI values. The results of that analysis are briefly summarized here.

- All $0.5^{\circ} \mathrm{NDVI}$ cells between $64 \mathrm{~N}$ and $50 \mathrm{~S}$ were used (total of 57,600 cells). 
- A subset was systematically selected (e.g., 1,5,9, . .) because there is a maximum limit of 30,000 points in Excel for doing regression. This process selected 14,400 cells which should be large enough to represent the whole profile.

- All pairs with -9999 were dropped.

- Regression analysis was performed for 4 representative months. The summary of the results is as follows:

\begin{tabular}{ccc}
\hline Month & $\mathrm{r}^{2}$ & Number \\
\hline Jan & 0.97 & 11,944 \\
Apr & 0.973 & 13,488 \\
Jul & 0.98 & 14,230 \\
0ct & 0.961 & 14,168 \\
\hline
\end{tabular}

11) A value of -9999 in the data set represents missing values. 
APPENDIX C

STATISTICAL ANALYSIS OF RATIOS OF BELOW GROUND NET PRIMARY PRODUCTIVITY TO TNPP TO DERIVE CONVERSIONS TO ESTIMATE TOTAL NPP 


\section{APPENDIX C: STATISTICAL ANALYSIS OF RATIOS OF BELOW GROUND NET PRIMARY PRODUCTIVITY TO TNPP TO DERIVE CONVERSIONS TO ESTIMATE TOTAL NPP}

For those sites lacking a value for TNPP, we estimated total NPP (NPP_EST) from ANPP or BNPP by calculated biome-specific ratios from sites that NPP measurements with both ANPP and BNPP. Table C.1 summarizes the calculated ratios for those sites having both above and below ground measurements by biome.

Table C.1. Ratios of below ground to total NPP estimates summarized by biome

\begin{tabular}{|c|c|c|c|c|c|c|c|}
\hline Biome & $\mathrm{N}$ & NMISS & MEAN & STD & STDERR & MIN & MAX \\
\hline \multicolumn{8}{|c|}{ BIOME - total of 21 classes } \\
\hline DBL forest / boreal & 3 & 39 & 0.155 & 0.032 & 0.019 & 0.125 & 0.189 \\
\hline DBL forest / temperate & 95 & 293 & 0.152 & 0.093 & 0.010 & 0.020 & 0.706 \\
\hline DBL forest / tropical & 29 & 17 & 0.218 & 0.110 & 0.020 & 0.061 & 0.432 \\
\hline DNL forest / boreal & 6 & 37 & 0.148 & 0.023 & 0.009 & 0.125 & 0.188 \\
\hline EBL forest / temperate & 9 & 366 & 0.152 & 0.042 & 0.014 & 0.109 & 0.209 \\
\hline EBL forest / tropical & 37 & 131 & 0.282 & 0.133 & 0.022 & 0.021 & 0.489 \\
\hline ENL forest / boreal & 60 & 171 & 0.266 & 0.148 & 0.019 & 0.038 & 0.647 \\
\hline ENL forest / temperate & 155 & 290 & 0.206 & 0.107 & 0.009 & 0.015 & 0.725 \\
\hline desert & 8 & 35 & 0.529 & 0.239 & 0.084 & 0.250 & 0.846 \\
\hline grassland / C3 & 35 & 33 & 0.561 & 0.195 & 0.033 & 0.063 & 0.840 \\
\hline grassland / & 20 & 12 & 0.571 & 0.160 & 0.036 & 0.208 & 0.788 \\
\hline C4temperate & & & & & & & \\
\hline grassland / C4tropical & 35 & 26 & 0.403 & 0.135 & 0.023 & 0.176 & 0.700 \\
\hline mixed forest & 44 & 137 & 0.166 & 0.065 & 0.010 & 0.064 & 0.305 \\
\hline tundra & 12 & 40 & 0.438 & 0.200 & 0.058 & 0.125 & 0.778 \\
\hline ALL & 551 & 1812 & 0.263 & 0.178 & 0.008 & 0.015 & 0.846 \\
\hline \multicolumn{8}{|c|}{ BIOME2 - aggregation into 12 classes } \\
\hline DBL forest / temperate & 95 & 293 & 0.152 & 0.093 & 0.010 & 0.020 & 0.706 \\
\hline DBL forest / tropical & 29 & 17 & 0.218 & 0.110 & 0.020 & 0.061 & 0.432 \\
\hline $\begin{array}{l}\text { DBL-DNL forest / } \\
\text { boreal }\end{array}$ & 9 & 76 & 0.150 & 0.024 & 0.008 & 0.125 & 0.189 \\
\hline EBL forest / temperate & 9 & 366 & 0.152 & 0.042 & 0.014 & 0.109 & 0.209 \\
\hline EBL forest / tropical & 37 & 131 & 0.282 & 0.133 & 0.022 & 0.021 & 0.489 \\
\hline ENL forest / boreal & 60 & 171 & 0.266 & 0.148 & 0.019 & 0.038 & 0.647 \\
\hline ENL forest / temperate & 156 & 291 & 0.208 & 0.108 & 0.009 & 0.015 & 0.725 \\
\hline desert & 8 & 35 & 0.529 & 0.239 & 0.084 & 0.250 & 0.846 \\
\hline grassland & 90 & 71 & 0.502 & 0.182 & 0.019 & 0.063 & 0.840 \\
\hline mixed forest & 44 & 137 & 0.166 & 0.065 & 0.010 & 0.064 & 0.305 \\
\hline savanna & 2 & 19 & 0.421 & 0.029 & 0.021 & 0.400 & 0.441 \\
\hline tundra & 12 & 40 & 0.438 & 0.200 & 0.058 & 0.125 & 0.778 \\
\hline ALL & 551 & 1812 & 0.263 & 0.178 & 0.008 & 0.015 & 0.846 \\
\hline
\end{tabular}

We calculate these ratios based on a consolidated biome classification with outliers excluded. The General Linear Model output from the SAS ${ }^{\mathrm{tm}}$ of the BNPP:TNPP ratios shows that there is a significant difference between biomes (Table C.2). We used the Duncan's Multiple Range option (Table C.3) to determine that the mean ratios for desert, grassland, tundra, and savanna biomes were significantly different $(\mathrm{p}=0.05)$ than the ratios for tropical, boreal, and temperate forest biomes. Based on our analysis, we used a ratio of 0.50 BNPP:TNPP for grasslands, deserts, and tundra and a ratio of 0.22 BNPP:TNPP for boreal, tropical, and temperate forests. 
Table C.2. Results of general linear models procedure on dependent variable: BNPP:TNPP

\begin{tabular}{llllll}
\hline Source & DF & Sum of squares & Mean square & F Value & Pr $>$ F \\
\hline Model & 6 & 8.0863 & 1.3477 & 79.11 & 0.0001 \\
Error & 544 & 9.2672 & 0.0170 & & \\
Corrected total & 550 & 17.3536 & & & \\
& & & & & \\
& R-Square & C.V. & Root MSE & BNPP TNPP & \\
& & & & mean & \\
& 0.465973 & 49.5496 & 0.1305 & 0.2634 & \\
Source & & & & & Pr $>$ F \\
BIOME3 & DF & Type I SS & Mean square & F Value & 0.0001 \\
Source & 6 & 8.0863 & 1.3477 & 79.11 & $\operatorname{Pr}>\mathrm{F}$ \\
BIOME3 & DF & Type III SS & Mean square & F Value & 0.0001 \\
\hline
\end{tabular}

Table C.3. Duncan's multiple range test for variable BNPP:TNPP with alpha $=0.05$, $\mathrm{df}=\mathbf{5 4 4}, \mathrm{MSE}=\mathbf{0 . 0 1 7 0 3 5}$

Means with the same letter are not significantly different. (NOTE: This test controls the type I comparison-wise error rate, not the experiment-wise error rate.)

\begin{tabular}{cccc}
\hline $\begin{array}{c}\text { Duncan } \\
\text { grouping }\end{array}$ & Mean & $\mathrm{N}$ & BIOME3 \\
\hline A & 0.52938 & 8 & desert \\
A & 0.50175 & 90 & grassland \\
A & 0.43813 & 12 & tundra \\
A & 0.42059 & 2 & savanna \\
B & 0.25424 & 66 & tropical \\
B & 0.25071 & 69 & boreal \\
B & 0.18280 & 304 & temperate \\
\hline
\end{tabular}


APPENDIX D

DATA SETS OF MODEL DRIVER AND VALIDATION VARIABLES 


\section{APPENDIX D: DATA SETS OF MODEL DRIVER AND VALIDATION VARIABLES}

Appendix D describes the overall content and organization of the GPPDI and the EMDI databases on terrestrial NPP. These data were used in the EMDI I Workshop held at the University of New Hampshire, Durham, New Hampshire, December 5-8, 1999, and the EMDI II workshop held at the NCEAS, Santa Barbara, California, April 18-21, 2001.

The NPP sites were categorized as either Class A, representing intensively-studied or well-documented study sites (e.g., with aboveground and below ground NPP, site-specific climate, soils information, etc.); Class B, representing more numerous "extensive" sites with less documentation and site-specific information available; or Class $\mathrm{C}$, representing regional collections of $0.5^{\circ}$ latitude-longitude grid cells.

Table D.1 describes the maturation of the GPPDI and EMDI databases. The set of Class C cells was expanded in October 2000, and the content and organization used with the expanded data is described in Appendix B. Table D.2 describes the data sets associated with GPPDI and EMDI, with Tables D.3-D.17 providing definitions of variables in each data set.

Table D.1. Maturation of the ecosystem model-data intercomparison database

\begin{tabular}{|c|c|c|c|c|}
\hline \multicolumn{3}{|c|}{ Number of records } & \multirow{2}{*}{$\begin{array}{c}\text { Date } \\
\text { compiled }\end{array}$} & \multirow[t]{2}{*}{ Description } \\
\hline Class A & Class B & Class C & & \\
\hline 162 & 2363 & 2768 & $\begin{array}{l}\text { June/July } \\
1999\end{array}$ & $\begin{array}{l}\text { Initial set of GPPDI NPP measurements, many sites with } \\
\text { multiple measurements }\end{array}$ \\
\hline 150 & 1690 & 2110 & $\begin{array}{l}\text { June/July } \\
1999\end{array}$ & Initial set of unique sites used to extract driver data \\
\hline 87 & 1271 & 1622 & $\begin{array}{l}\text { December } \\
1999\end{array}$ & Set of sites with both NPP and driver data \\
\hline 151 & 1689 & 2696 & March 2000 & NPP measurements passing outlier review \\
\hline 81 & 933 & 1637 & March 2000 & $\begin{array}{l}\text { Set of sites with outliers excluded and means of multiple } \\
\text { measurements }\end{array}$ \\
\hline \multicolumn{5}{|c|}{ Expanded Class C cells } \\
\hline \multirow{3}{*}{\multicolumn{2}{|c|}{$\begin{array}{l}\text { No change in data for } \\
\text { the Class A and B } \\
\text { sites }\end{array}$}} & 5,164 & $\begin{array}{l}\text { October } \\
2000\end{array}$ & $\begin{array}{l}\text { Expanded set of Class C grid cell NPP measurements, } \\
\text { some sites with multiple measurements (includes } 2396 \text { new } \\
\text { values in addition to the } 2768 \text { available in July 1999) }\end{array}$ \\
\hline & & 3,980 & $\begin{array}{l}\text { October } \\
2000\end{array}$ & Set of unique Class $\mathrm{C}$ grid cells with driver data \\
\hline & & 3,855 & $\begin{array}{l}\text { January } \\
2001\end{array}$ & $\begin{array}{l}\text { Expanded set of Class C grid cell NPP measurements } \\
\text { passing outlier review }\end{array}$ \\
\hline
\end{tabular}

The GPPDI and EMDI databases contain 40 primary data sets, plus an additional 570 data sets of monthly climate data for Class A sites. There are approximately 200 variables, plus monthly data for a variety of climate parameters. The databases include the assignment of consistent biome class (BIOMENEW) to all sites, standardized latitude and longitude to 2 decimal places, and assigned unique identifiers for locations (SITE_ID) and individual measurements (MEAS_ID) within classes for linking with model driver data and validation data. Appendix D provides variable names, units of measure, and sources of data for each data set in the EMDI database. Often the "XXX" in the name is used to refer to a convention of including the number of records in the data set as part of the data set name. In addition, the numbers of observations of each variable are provided for Classes $\mathrm{A}, \mathrm{B}$, and $\mathrm{C}$ sites, with an $\mathrm{X}$ in a cell indicating the number of observations for that variable. The data sets are grouped into:

1) site characteristics data sets derived from site-specific sources (Tables D.3-D.6);

2) model driver data sets derived from global sources (Tables D.7-D.13); and

3) model validation data sets (Tables D.14-D.17), i.e., the NPP data. 
Table D.2. Descriptions of data sets where xxx in data set name indicates the number of observations in the data set, e.g., 81,933 , and 1627 for Class A, B, and C sets, respectively

\begin{tabular}{|c|c|c|}
\hline $\begin{array}{c}\text { Table } \\
\text { number }\end{array}$ & Data set name & Description \\
\hline & \multicolumn{2}{|c|}{ Model driver data sets derived from site-specific sources } \\
\hline 3 & Site_xxx.csv & Site information (elevation, country name, annual climate) from the ORNL NPP database \\
\hline 4 & Veg_xxx.csv & $\begin{array}{l}\text { Site-specific vegetation/species information from the ORNL NPP database, as provided by the original } \\
\text { source }\end{array}$ \\
\hline 5 & Soil_xxx.csv & Site-specific soils information from the ORNL NPP database, as provided by the original source \\
\hline 6 & TMĀXsite.csv & $\begin{array}{l}\text { Site-specific monthly maximum temperature data from the ORNL NPP database, including climate data for } \\
38 \text { sites and averaging } 40 \text { years per site }\end{array}$ \\
\hline 6 & TMINsite.csv & $\begin{array}{l}\text { Site-specific monthly minimum temperature data from the ORNL NPP database, including climate data for } \\
38 \text { sites and averaging } 40 \text { years per site }\end{array}$ \\
\hline \multirow[t]{2}{*}{6} & PRECsite.csv & $\begin{array}{l}\text { Site-specific monthly precipitation data from the ORNL NPP database, including climate data for } 38 \text { sites } \\
\text { and averaging } 40 \text { years per site }\end{array}$ \\
\hline & \multicolumn{2}{|c|}{ Model driver data sets derived from global sources } \\
\hline 7 & Summ_xxx.csv & $\begin{array}{l}\text { Summary information extracted from each of the global data sets: annual climate, soil texture, dominant } \\
\text { land cover type. }\end{array}$ \\
\hline 8 & CoverUMD.csv & Land cover based on 14 cover classes, compiled by the University of Maryland \\
\hline 9 & SoillGBP.csv & Soil texture, $\mathrm{pH}$, carbon and nitrogen density, compiled from the IGBP global database \\
\hline 10 & NDVI_UNH.csv & $\begin{array}{l}\text { Average monthly NDVI values based on available data for 1986, 1987, and 1990, compiled by the } \\
\text { University of New Hampshire }\end{array}$ \\
\hline 11 & TAVE_PIK.csv & Monthly average temperature, compiled by the Potsdam Institute for Climate Impact Research (PIK) \\
\hline 11 & TMAX_PIK.csv & Monthly maximum temperature, compiled by PIK \\
\hline 11 & TMIN_PIK.csv & Monthly minimum temperature, compiled by PIK \\
\hline 11 & PREC_PIK.csv & Monthly total precipitation, compiled by PIK \\
\hline 11 & SUN_PIK.csv & Monthly percentage sunshine for daylight hours, compiled by PIK \\
\hline 12 & CO2_95.csv & $\begin{array}{l}\text { Estimates of annual global atmospheric CO2 levels for 1901-1995, compiled by the ORNL Carbon Dioxide } \\
\text { Information and Analysis Center (CDIAC) }\end{array}$ \\
\hline & \multicolumn{2}{|c|}{ 95-Year monthly climates for Class A sites only } \\
\hline 13 & $<$ temp_years $>$ & $\begin{array}{l}\text { Actual monthly average temperatures for 1901-1995 with separate files for each year containing data for all } \\
\text { sites, compiled by PIK }\end{array}$ \\
\hline 13 & $<$ tmax_years $>$ & $\begin{array}{l}\text { Actual monthly maximum temperatures for } 1901-1995 \text { with separate files for each year containing data for } \\
\text { all sites, compiled by PIK }\end{array}$ \\
\hline 13 & $<$ tmin_years $>$ & $\begin{array}{l}\text { Actual monthly minimum temperatures for } 1901-1995 \text { with separate files for each year containing data for } \\
\text { all sites, compiled by PIK }\end{array}$ \\
\hline 13 & $<$ dtr_years $>$ & $\begin{array}{l}\text { Actual monthly diurnal temperature range for 1901-1995 with separate files for each year containing data } \\
\text { for all sites, compiled by PIK }\end{array}$ \\
\hline 13 & $<$ prec_years $>$ & $\begin{array}{l}\text { Actual monthly precipitation for 1901-1995 with separate files for each year containing data for all sites, } \\
\text { compiled by PIK }\end{array}$ \\
\hline \multirow[t]{2}{*}{13} & $<$ sun_years $>$ & $\begin{array}{l}\text { Actual monthly sunshine for } 1901-1995 \text { with separate files for each year containing data for all sites, } \\
\text { compiled by PIK }\end{array}$ \\
\hline & \multicolumn{2}{|c|}{ Model validation data sets } \\
\hline 14 & NPP_xxx.csv & $\begin{array}{l}\text { Individual NPP measurements for sites with BIOMENEW, lat/long expressed with } 2 \text { decimal places, and } \\
\text { unique SITE_ID and MEAS_ID added for linking with model driver data. These are the GPPDI NPP data } \\
\text { sets. }\end{array}$ \\
\hline 15 & FLAGS_xxx.csv & Flags associated with the outlier analysis. \\
\hline 16 & MEANS_XXxx.csv & $\begin{array}{l}\text { Mean NPP measurements for unique sites based on those NPP measurements that were not flagged during } \\
\text { the outlier analysis. These are the EMDI NPP data sets. }\end{array}$ \\
\hline 17 & DRIVER_xxx.csv & Driver data associated with each site. \\
\hline
\end{tabular}


Table D.3. Model driver location information derived from site-specific sources

\begin{tabular}{|c|c|c|c|c|c|c|}
\hline Variable & Units & Description & Source & \multicolumn{3}{|c|}{ Class } \\
\hline \multicolumn{4}{|c|}{ SITE_xxx - Location information } & A & $\mathrm{B}$ & $\mathrm{C}$ \\
\hline SITE_ID & N/A & Site ID number based on unique lat/long & Assigned & 81 & $\mathrm{X}$ & 1637 \\
\hline SITE_OLD & N/A & Unique site number & Assigned & $\mathrm{X}$ & $\mathrm{X}$ & $\mathrm{X}$ \\
\hline LAT_DD & Decimal degrees & Latitude $\mathrm{xx} . \mathrm{xx}$ & As given & 81 & $\mathrm{X}$ & 1637 \\
\hline LONG_DD & Decimal degrees & Longitude $\mathrm{xx} \cdot \mathrm{xx}$ & As given & 81 & $\mathrm{X}$ & 1637 \\
\hline BIOME & N/A & Biome type as given, somewhat standardized & As given & $\mathrm{X}$ & $\mathrm{X}$ & 1637 \\
\hline ELEV_GIV & Meters & Elevation as given for the site & As given & 54 & $\mathrm{X}$ & $\mathrm{X}$ \\
\hline ELEV_DEM & Meters & $\begin{array}{l}\text { Elevation extracted from a global DEM }(1 \mathrm{~km} \\
\text { resolution) }\end{array}$ & $\begin{array}{l}\text { Extracted from a } \\
\text { global DEM (1 km } \\
\text { resolution) }\end{array}$ & 81 & $\mathrm{X}$ & 1637 \\
\hline ELEV_N & N/A & Number of elevation measurements for this site & Calculated & $\mathrm{X}$ & $\mathrm{X}$ & 1637 \\
\hline COUNTRY & $\mathrm{N} / \mathrm{A}$ & Country name & As given & 81 & $\mathrm{X}$ & $\mathrm{X}$ \\
\hline TAVE_ANN & ${ }^{\circ} \mathrm{C}$ & Annual average temperature & As given & 64 & $\mathrm{X}$ & $\mathrm{X}$ \\
\hline TMIN_ANN & ${ }^{\circ} \mathrm{C}$ & Annual minimum temperature & As given & 28 & $\mathrm{X}$ & $\mathrm{X}$ \\
\hline TMAX̄_ANN & ${ }^{\circ} \mathrm{C}$ & Annual maximum temperature & As given & 28 & $\mathrm{X}$ & $\mathrm{X}$ \\
\hline PREC_ANN & Millimeters & Annual total precipitation & As given & 70 & $\mathrm{X}$ & $\mathrm{X}$ \\
\hline FLAG_LOC & Coded & $\begin{array}{l}\text { Flag indicating potential problems with the } \\
\text { location variables (lat/long/elev) }\end{array}$ & Assigned & $\mathrm{X}$ & $\mathrm{X}$ & $\mathrm{X}$ \\
\hline
\end{tabular}

Table D.4. Model driver site soils information derived from site-specific sources

\begin{tabular}{|c|c|c|c|c|c|c|}
\hline Variable & Units & Description & Source & \multicolumn{3}{|c|}{ Class } \\
\hline \multicolumn{4}{|c|}{ SOIL_xxx - Site soils information } & $\mathrm{A}$ & $\mathrm{B}$ & $\mathrm{C}$ \\
\hline SITE_ID & N/A & Site ID number based on unique lat/long & Assigned & 81 & $\mathrm{X}$ & $\mathrm{X}$ \\
\hline LAT_DD & Decimal degrees & Latitude $\mathrm{xx} . \mathrm{xx}$ & As given & 81 & $\mathrm{X}$ & $\mathrm{X}$ \\
\hline LONG_DD & Decimal degrees & Longitude $\mathrm{xxx} . \mathrm{xx}$ & As given & 81 & $\mathrm{X}$ & $\mathrm{X}$ \\
\hline $\mathrm{SOIL}^{-}$ & N/A & Soil type as given & As given & 81 & $\mathrm{X}$ & $\mathrm{X}$ \\
\hline SOIL_BLK & & Soil bulk density as given & As given & 81 & $\mathrm{X}$ & $\mathrm{X}$ \\
\hline SOIL_PH & & Soil $\mathrm{pH}$ as given & As given & 81 & $\mathrm{X}$ & $\mathrm{X}$ \\
\hline SOIL_TXT & & Soil texture as given & As given & 81 & $\mathrm{X}$ & $\mathrm{X}$ \\
\hline SOIL C & & Soil carbon as given & As given & 81 & $\mathrm{X}$ & $\mathrm{X}$ \\
\hline SOIL $^{-} \mathrm{N}$ & & Soil nitrogen as given & As given & 81 & $\mathrm{X}$ & $\mathrm{X}$ \\
\hline
\end{tabular}

Table D.5. Model driver site vegetation information derived from site-specific sources

\begin{tabular}{|c|c|c|c|c|c|c|}
\hline Variable & Units & $\begin{array}{r}\text { Description } \\
\end{array}$ & Source & \multicolumn{3}{|c|}{ Class } \\
\hline \multicolumn{4}{|c|}{ VEG_xxx - Site vegetation information } & A & $\mathrm{B}$ & $\mathrm{C}$ \\
\hline SITE_ID & N/A & Site ID number based on unique lat/long & Assigned & 81 & $\mathrm{X}$ & $\mathrm{X}$ \\
\hline LAT DD & Decimal degrees & Latitude $\mathrm{xx} . \mathrm{xx}$ & As given & 81 & $\mathrm{X}$ & $\mathrm{X}$ \\
\hline LONG_DD & Decimal degrees & Longitude $\mathrm{xxx} . \mathrm{xx}$ & As given & 81 & $\mathrm{X}$ & $\mathrm{X}$ \\
\hline BIOME & N/A & Biome type as given, somewhat standardized & As given & 81 & $\mathrm{X}$ & $\mathrm{X}$ \\
\hline VEG_TYPE & N/A & Vegetation type as given, somewhat standardized & As given & 73 & $\mathrm{X}$ & $\mathrm{X}$ \\
\hline SPECIES & $\mathrm{N} / \mathrm{A}$ & Dominant species & As given & 67 & $\mathrm{X}$ & $\mathrm{X}$ \\
\hline STAND_AGE & Years & Stand age, if known & As given & $\mathrm{X}$ & $\mathrm{X}$ & $\mathrm{X}$ \\
\hline DISTURB_Y & Years & Years since last disturbance, if known & As given & $\mathrm{X}$ & $\mathrm{X}$ & $\mathrm{X}$ \\
\hline MNGMT & N/A & Site management, if known & As given & 18 & $\mathrm{X}$ & $\mathrm{X}$ \\
\hline
\end{tabular}


Table D.6. Model driver monthly temperature (Tmax, Tmin) and precipitation climate data from site-specific sources for 38 Class A sites, averaging 40 years of observations per site

\begin{tabular}{|c|c|c|c|c|c|c|}
\hline Variable & Units & Description & Source & \multicolumn{3}{|c|}{ Class } \\
\hline \multicolumn{4}{|c|}{ Site-specific monthly Tmax, Tmin, and Prec Climate } & A & $\mathrm{B}$ & $\mathrm{C}$ \\
\hline SITE_ID & N/A & Site ID number based on unique lat/long & Assigned & 1537 & $\mathrm{X}$ & $\mathrm{X}$ \\
\hline LAT_DD & Decimal degrees & Latitude $\mathrm{xx} . \mathrm{xx}$ & As given & 1537 & $\mathrm{X}$ & $\mathrm{X}$ \\
\hline LONG_DD & Decimal degrees & Longitude $\mathrm{xxx} . \mathrm{xx}$ & As given & 1537 & $\mathrm{X}$ & $\mathrm{X}$ \\
\hline PARM $^{-}$ & N/A & Parameter measured - Tmax, Tmin, and Prec & As given & 1537 & $\mathrm{X}$ & $\mathrm{X}$ \\
\hline JAN & $\begin{array}{l}\text { Based on PARM: }{ }^{\circ} \text {, } \\
\text { millimeters }\end{array}$ & Climate values for month & As given & 1537 & $\mathrm{X}$ & $\mathrm{X}$ \\
\hline FEB & $\begin{array}{l}\text { Based on PARM: }{ }^{\circ} \text {, } \\
\text { millimeters }\end{array}$ & Climate values for month & As given & 1537 & $\mathrm{X}$ & $\mathrm{X}$ \\
\hline MAR & $\begin{array}{l}\text { Based on PARM: }{ }^{\circ} \text {, } \\
\text { millimeters }\end{array}$ & Climate values for month & As given & 1537 & $\mathrm{X}$ & $\mathrm{X}$ \\
\hline APR & $\begin{array}{l}\text { Based on PARM: }{ }^{\circ} \text {, } \\
\text { millimeters }\end{array}$ & Climate values for month & As given & 1537 & $\mathrm{X}$ & $\mathrm{X}$ \\
\hline MAY & $\begin{array}{l}\text { Based on PARM: }{ }^{\circ} \text {, } \\
\text { millimeters }\end{array}$ & Climate values for month & As given & 1537 & $\mathrm{X}$ & $\mathrm{X}$ \\
\hline JUN & $\begin{array}{l}\text { Based on PARM: }{ }^{\circ} \text {, } \\
\text { millimeters }\end{array}$ & Climate values for month & As given & 1537 & $\mathrm{X}$ & $\mathrm{X}$ \\
\hline JUL & $\begin{array}{l}\text { Based on PARM: }{ }^{\circ} \text {, } \\
\text { millimeters }\end{array}$ & Climate values for month & As given & 1537 & $\mathrm{X}$ & $\mathrm{X}$ \\
\hline AUG & $\begin{array}{l}\text { Based on PARM: }{ }^{\circ} \text {, } \\
\text { millimeters }\end{array}$ & Climate values for month & As given & 1537 & $\mathrm{X}$ & $\mathrm{X}$ \\
\hline SEP & $\begin{array}{l}\text { Based on PARM: }{ }^{\circ} \text {, } \\
\text { millimeters }\end{array}$ & Climate values for month & As given & 1537 & $\mathrm{X}$ & $\mathrm{X}$ \\
\hline OCT & $\begin{array}{l}\text { Based on PARM: }{ }^{\circ} \text {, } \\
\text { millimeters }\end{array}$ & Climate values for month & As given & 1537 & $\mathrm{X}$ & $\mathrm{X}$ \\
\hline NOV & $\begin{array}{l}\text { Based on PARM: }{ }^{\circ} \text {, } \\
\text { millimeters }\end{array}$ & Climate values for month & As given & 1537 & $\mathrm{X}$ & $\mathrm{X}$ \\
\hline $\mathrm{DEC}$ & $\begin{array}{l}\text { Based on PARM: }{ }^{\circ} \text {, } \\
\text { millimeters }\end{array}$ & Climate values for month & As given & 1537 & $\mathrm{X}$ & $\mathrm{X}$ \\
\hline YR & $\begin{array}{l}\text { Based on PARM: }{ }^{\circ} \text {, } \\
\text { millimeters }\end{array}$ & Climate values for year & $\begin{array}{l}\text { Calculated from } 12 \\
\text { months }\end{array}$ & 1537 & $\mathrm{X}$ & $\mathrm{X}$ \\
\hline \multicolumn{4}{|c|}{ Three data sets contain climate data described above for each of the climate parameters defined below: } & A & $\mathrm{B}$ & $\mathrm{C}$ \\
\hline TMIN & ${ }^{\circ} \mathrm{C}$ & Temperature - average monthly minimum & & & & \\
\hline TMAX & ${ }^{\circ} \mathrm{C}$ & Temperature - average monthly maximum & & & & \\
\hline PREC & Millimeters & Precipitation - annual total & & & & \\
\hline
\end{tabular}

Table D.7. Model driver summary information derived from global sources

\begin{tabular}{|c|c|c|c|c|c|c|}
\hline Variable & Units & Description & Source & \multicolumn{3}{|c|}{ Class } \\
\hline \multicolumn{4}{|c|}{ SUMM_xxx - Summary information based on global extractions } & $\mathrm{A}$ & $\mathrm{B}$ & $\mathrm{C}$ \\
\hline SITE_ID & N/A & Site ID number based on unique lat/long & Assigned & 81 & 933 & 1637 \\
\hline LAT_DD & Decimal degrees & Latitude xx.xx & As given & 81 & 933 & 1637 \\
\hline LONG_DD & Decimal degrees & Longitude $\mathrm{xxx} . \mathrm{xx}$ & As given & 81 & 933 & 1637 \\
\hline ELEV_GIV & Meters & Elevation as given for the site & As given & 81 & 933 & 1637 \\
\hline ELEV_DEM & Meters & $\begin{array}{l}\text { Elevation extracted from a global DEM }(1 \mathrm{~km} \\
\text { resolution) }\end{array}$ & $\begin{array}{l}\text { Extracted from a } \\
\text { global DEM }(1 \mathrm{~km} \\
\text { resolution })\end{array}$ & 81 & 933 & 1637 \\
\hline SAND & $\% \mathrm{w} / \mathrm{w}$ & Sand content in top $30 \mathrm{~cm}$ & $\begin{array}{l}\text { IGBP Soils } \\
\text { Database (extracted } \\
\text { by Olson) }\end{array}$ & 81 & 933 & 1637 \\
\hline SILT & $\% \mathrm{w} / \mathrm{w}$ & Silt content in top $30 \mathrm{~cm}$ & $\begin{array}{l}\text { IGBP Soils } \\
\text { Database (extracted } \\
\text { by Olson) }\end{array}$ & 81 & 933 & 1637 \\
\hline CLAY & $\% \mathrm{w} / \mathrm{w}$ & Clay content in top $30 \mathrm{~cm}$ & $\begin{array}{l}\text { IGBP Soils } \\
\text { Database (extracted } \\
\text { by Olson) }\end{array}$ & 81 & 933 & 1637 \\
\hline TAVE & ${ }^{\circ} \mathrm{C}$ & Temperature - long-term ( 30 y) monthly average & $\begin{array}{l}\text { Leemans and } \\
\text { Cramer (extracted } \\
\text { by Cramer) }\end{array}$ & 81 & 933 & 1637 \\
\hline
\end{tabular}


Table D.7 (continued)

\begin{tabular}{|c|c|c|c|c|c|c|}
\hline Variable & Units & Description & Source & \multicolumn{3}{|c|}{ Class } \\
\hline \multicolumn{4}{|c|}{ SUMM_xxx - Summary information based on global extractions } & $\mathrm{A}$ & $\mathrm{B}$ & $\mathrm{C}$ \\
\hline TMIN & ${ }^{\circ} \mathrm{C}$ & $\begin{array}{l}\text { Temperature - long-term ( } 30 \mathrm{y}) \text { average monthly } \\
\text { minimum }\end{array}$ & $\begin{array}{l}\text { Leemans and } \\
\text { Cramer (extracted } \\
\text { by Cramer) }\end{array}$ & 81 & 933 & 1637 \\
\hline TMAX & ${ }^{\circ} \mathrm{C}$ & $\begin{array}{l}\text { Temperature - long-term ( } 30 \text { y) average monthly } \\
\text { maximum }\end{array}$ & $\begin{array}{l}\text { Leemans and } \\
\text { Cramer (extracted } \\
\text { by Cramer) }\end{array}$ & 81 & 933 & 1637 \\
\hline PREC & Millimeters & $\begin{array}{l}\text { Precipitation - long-term (30 y) average annual } \\
\text { total }\end{array}$ & $\begin{array}{l}\text { Leemans and } \\
\text { Cramer (extracted } \\
\text { by Cramer) }\end{array}$ & 81 & 933 & 1637 \\
\hline SUN & $\%$ & $\begin{array}{l}\text { Sunshine - long-term ( } 30 \mathrm{y}) \text { average percentage } \\
\text { of hours of sunshine per daylight hours }\end{array}$ & $\begin{array}{l}\text { Leemans and } \\
\text { Cramer (extracted } \\
\text { by Cramer) }\end{array}$ & 81 & 933 & 1637 \\
\hline COVR1KM & Code & $\begin{array}{l}\text { Dominant land cover based on a } 1 \mathrm{~km} \text { grid cell } \\
\text { centered on the site }\end{array}$ & $\begin{array}{l}\text { DeFries \& } \\
\text { Townsend (extracted } \\
\text { by Prince) }\end{array}$ & 81 & 933 & 1637 \\
\hline COVR50KM & Code & $\begin{array}{l}\text { Dominant land cover based on } 0.5^{\circ} \text { grid cell } \\
\text { centered the on site }\end{array}$ & $\begin{array}{l}\text { DeFries \& } \\
\text { Townsend (extracted } \\
\text { by Prince) }\end{array}$ & 81 & 933 & 1637 \\
\hline COVTYPES & Code & $\begin{array}{l}\text { Dominant land cover frequencies based on } 0.5^{\circ} \\
\text { grid cell }\end{array}$ & $\begin{array}{l}\text { DeFries \& } \\
\text { Townsend (extracted } \\
\text { by Prince) }\end{array}$ & $X$ & 933 & 1637 \\
\hline
\end{tabular}

Table D.8. Model driver land cover information derived from global sources

\begin{tabular}{|c|c|c|c|c|c|c|}
\hline Variable & Units & Description & Source & \multicolumn{3}{|c|}{ Class } \\
\hline \multicolumn{4}{|c|}{ COVER_UMD - Land cover extracted from DeFries and Townsend for 9x9 1 km cells } & A & $\mathrm{B}$ & $\mathrm{C}$ \\
\hline SITE_ID & N/A & Site ID number based on unique lat/long & Assigned & 81 & 933 & 1637 \\
\hline LAT_DD & Decimal degrees & Latitude $\mathrm{xx} . \mathrm{xx}$ & As given & 81 & 933 & 1637 \\
\hline LONG_DD & Decimal degrees & Longitude $\mathrm{xxx} . \mathrm{xx}$ & As given & 81 & 933 & 1637 \\
\hline WATER & $\%$ & Landcover 0 - Water & $\begin{array}{l}\text { DeFries \& } \\
\text { Townsend } \\
\text { (Extracted by } \\
\text { Prince) }\end{array}$ & 81 & $\mathrm{X}$ & $\mathrm{X}$ \\
\hline NEEDLE_E & $\%$ & Landcover 1 - Evergreen needleleaf Forests & Same source & 81 & $\mathrm{X}$ & $\mathrm{X}$ \\
\hline BROAD_E & $\%$ & Landcover 2 - Evergreen broadleaf Forests & Same source & 81 & $\mathrm{X}$ & $\mathrm{X}$ \\
\hline NEEDLE_D & $\%$ & Landcover 3 - Deciduous needleleaf Forests & Same source & 81 & $\mathrm{X}$ & $\mathrm{X}$ \\
\hline BROAD_D & $\%$ & Landcover 4 - Deciduous broadleaf Forests & Same source & 81 & $\mathrm{X}$ & $\mathrm{X}$ \\
\hline MIXED & $\%$ & Landcover 5 - Mixed forests & Same source & 81 & $\mathrm{X}$ & $\mathrm{X}$ \\
\hline WOODLAND & $\%$ & Landcover 6 - Woodlands & Same source & 81 & $\mathrm{X}$ & $\mathrm{X}$ \\
\hline WOODGRSS & $\%$ & Landcover 7 - Wooded Grasslands/ Shrubs & Same source & 81 & $\mathrm{X}$ & $\mathrm{X}$ \\
\hline SHRUB_CL & $\%$ & Landcover 8 - Closed Bushlands or Shrublands & Same source & 81 & $\mathrm{X}$ & $\mathrm{X}$ \\
\hline SHRUB_OP & $\%$ & Landcover 9 - Open Shrublands & Same source & 81 & $\mathrm{X}$ & $\mathrm{X}$ \\
\hline GRASS & $\%$ & Landcover 10 - Grasses & Same source & 81 & $\mathrm{X}$ & $\mathrm{X}$ \\
\hline CROP & $\%$ & Landcover 11 - Croplands & Same source & 81 & $\mathrm{X}$ & $\mathrm{X}$ \\
\hline BARE & $\%$ & Landcover 12 - Bare & Same source & 81 & $\mathrm{X}$ & $\mathrm{X}$ \\
\hline URBAN & $\%$ & Landcover 13 - Mosses and lichens & Same source & 81 & $\mathrm{X}$ & $\mathrm{X}$ \\
\hline COVR1KM & Code & $\begin{array}{l}\text { Dominant land cover based on a } 5 \text { x } 5 \text { set of } 1 \mathrm{~km} \\
\text { grid cells }\end{array}$ & Same source & 81 & 933 & 1637 \\
\hline COVR50KM & Code & $\begin{array}{l}\text { Dominant land cover based on } 0.5^{\circ} \text { grid cell } \\
\text { centered on site }\end{array}$ & Same source & 81 & 933 & 1637 \\
\hline COVTYPES & Code & $\begin{array}{l}\text { Dominant land cover frequencies based on } 0.5^{\circ} \\
\text { grid cell }\end{array}$ & Same source & $\mathrm{X}$ & 933 & 1637 \\
\hline
\end{tabular}


Table D.9. Model driver soils information derived from global sources

\begin{tabular}{|c|c|c|c|c|c|c|}
\hline Variable & Units & Description & Source & \multicolumn{3}{|c|}{ Class } \\
\hline \multicolumn{4}{|c|}{ SOILIGBP - Soils information extracted for 5 ' grid cell } & A & $\mathrm{B}$ & $\mathrm{C}$ \\
\hline SITE_ID & N/A & Site ID number based on unique lat/long & Assigned & 81 & 933 & 1637 \\
\hline LAT_DD & Decimal degrees & Latitude xx.xx & As given & 81 & 933 & 1637 \\
\hline LONG_DD & Decimal degrees & Longitude $\mathrm{xxx} . \mathrm{xx}$ & As given & 81 & 933 & 1637 \\
\hline SAND & $\% \mathrm{w} / \mathrm{w}$ & Sand content in top $30 \mathrm{~cm}$ & $\begin{array}{l}\text { IGBP Soils } \\
\text { Database (extracted } \\
\text { by Olson) }\end{array}$ & 81 & 933 & 1637 \\
\hline SILT & $\% \mathrm{w} / \mathrm{w}$ & Silt content in top $30 \mathrm{~cm}$ & Same source & 81 & 933 & 1637 \\
\hline CLAY & $\% \mathrm{w} / \mathrm{w}$ & Clay content in top $30 \mathrm{~cm}$ & Same source & 81 & 933 & 1637 \\
\hline SOILN30 & $\mathrm{g} \mathrm{m}^{-2}$ & Soil nitrogen in top $30 \mathrm{~cm}$ & Same source & 81 & 933 & 1637 \\
\hline SOILN20 & $\mathrm{g} \mathrm{m}^{-2}$ & Soil nitrogen in top $20 \mathrm{~cm}$ & Same source & 81 & 933 & 1637 \\
\hline SOILN100 & $\mathrm{g} \mathrm{m}^{-2}$ & Soil nitrogen in top $100 \mathrm{~cm}$ & Same source & 81 & 933 & 1637 \\
\hline SOILC30 & $\mathrm{Kg} \mathrm{m}^{-2}$ & Soil carbon in top $30 \mathrm{~cm}$ & Same source & 81 & 933 & 1637 \\
\hline SOILC20 & $\mathrm{Kg} \mathrm{m}^{-2}$ & Soil carbon in top $20 \mathrm{~cm}$ & Same source & 81 & 933 & 1637 \\
\hline SOILC100 & $\mathrm{Kg} \mathrm{m}^{-2}$ & Soil carbon in top $100 \mathrm{~cm}$ & Same source & 81 & 933 & 1637 \\
\hline $\mathrm{PH}$ & N/A & Soil $\mathrm{pH}$ (water) in top $30 \mathrm{~cm}$ & Same source & 81 & 933 & 1637 \\
\hline $\mathrm{BD}$ & $\mathrm{g} \mathrm{cm}^{-1}$ & Bulk density of top $30 \mathrm{~cm}$ & Same source & 81 & 933 & 1637 \\
\hline $\mathrm{FC}$ & Millimeters & $\begin{array}{l}\text { Field capacity (water holding capacity) in top } 30 \\
\mathrm{~cm}\end{array}$ & Same source & 81 & 933 & 1637 \\
\hline WP & Millimeters & Wilting point for top $30 \mathrm{~cm}$ & Same source & 81 & 933 & 1637 \\
\hline PAWC & Millimeters & Profile available water capacity & Same source & 81 & 933 & 1637 \\
\hline
\end{tabular}

Table D.10. Model driver average monthly NDVI information derived from global sources

\begin{tabular}{|c|c|c|c|c|c|c|}
\hline Variable & Units & Description & Source & \multicolumn{3}{|c|}{ Class } \\
\hline \multicolumn{4}{|c|}{ NDVI_UNH - Average monthly NDVI based on 1986,1987 , and 1990} & $\mathrm{~A}$ & $\mathrm{~B}$ & $\mathrm{C}$ \\
\hline SITE_ID & N/A & Site ID number based on unique lat/long & Assigned & 81 & 933 & 1637 \\
\hline LAT_DD & Decimal degrees & Latitude $\mathrm{xx} . \mathrm{xx}$ & As given & 81 & 933 & 1637 \\
\hline LONG_DD & Decimal degrees & Longitude $\mathrm{xxx} . \mathrm{xx}$ & As given & 81 & 933 & 1637 \\
\hline JAN & & NDVI - mean of 1986, 1987, and 1990 & $\begin{array}{l}\text { Pathfinder AVHRR } \\
\text { Land (PAL) }\end{array}$ & 81 & 933 & 1637 \\
\hline FEB & & NDVI - mean of 1986, 1987, and 1990 & Same source & 81 & 933 & 1637 \\
\hline MAR & & NDVI - mean of 1986, 1987, and 1990 & Same source & 81 & 933 & 1637 \\
\hline APR & & NDVI - mean of 1986, 1987, and 1990 & Same source & 81 & 933 & 1637 \\
\hline MAY & & NDVI - mean of 1986, 1987, and 1990 & Same source & 81 & 933 & 1637 \\
\hline JUN & & NDVI - mean of 1986,1987 , and 1990 & Same source & 81 & 933 & 1637 \\
\hline JUL & & NDVI - mean of 1986,1987 , and 1990 & Same source & 81 & 933 & 1637 \\
\hline AUG & & NDVI - mean of 1986, 1987, and 1990 & Same source & 81 & 933 & 1637 \\
\hline SEP & & NDVI - mean of 1986, 1987, and 1990 & Same source & 81 & 933 & 1637 \\
\hline OCT & & NDVI - mean of 1986, 1987, and 1990 & Same source & 81 & 933 & 1637 \\
\hline NOV & & NDVI - mean of 1986, 1987, and 1990 & Same source & 81 & 933 & 1637 \\
\hline DEC & & NDVI - mean of 1986, 1987, and 1990 & Same source & 81 & 933 & 1637 \\
\hline JAN_STD & & NDVI - standard deviation & Calculated & 81 & 933 & 1637 \\
\hline FEB_STD & & NDVI - standard deviation & Calculated & 81 & 933 & 1637 \\
\hline MAR_STD & & NDVI - standard deviation & Calculated & 81 & 933 & 1637 \\
\hline APR_STD & & NDVI - standard deviation & Calculated & 81 & 933 & 1637 \\
\hline MAY__STD & & NDVI - standard deviation & Calculated & 81 & 933 & 1637 \\
\hline JUN_STD & & NDVI - standard deviation & Calculated & 81 & 933 & 1637 \\
\hline JUL_STD & & NDVI - standard deviation & Calculated & 81 & 933 & 1637 \\
\hline AUG_STD & & NDVI - standard deviation & Calculated & 81 & 933 & 1637 \\
\hline SEP_STD & & NDVI - standard deviation & Calculated & 81 & 933 & 1637 \\
\hline OCT_STD & & NDVI - standard deviation & Calculated & 81 & 933 & 1637 \\
\hline NOV_STD & & NDVI - standard deviation & Calculated & 81 & 933 & 1637 \\
\hline DEC_STD & & NDVI - standard deviation & Calculated & 81 & 933 & 1637 \\
\hline JAN_N & & NDVI - number of years in mean $(0-3)$ & Calculated & 81 & 933 & 1637 \\
\hline FEB_N & & NDVI - number of years in mean (0-3) & Calculated & 81 & 933 & 1637 \\
\hline MAR_N & & NDVI - number of years in mean $(0-3)$ & Calculated & 81 & 933 & 1637 \\
\hline APR_N & & NDVI - number of years in mean $(0-3)$ & Calculated & 81 & 933 & 1637 \\
\hline MAY__N & & NDVI - number of years in mean (0-3) & Calculated & 81 & 933 & 1637 \\
\hline JUN_- & & NDVI - number of years in mean $(0-3)$ & Calculated & 81 & 933 & 1637 \\
\hline
\end{tabular}


Table D.10 (continued)

\begin{tabular}{|c|c|c|c|c|c|c|}
\hline Variable & Units & Description & Source & \multicolumn{3}{|c|}{ Class } \\
\hline & NDVI_UNH & monthly NDVI based on 1986,1987 , and 1990 & & A & B & $\mathrm{C}$ \\
\hline JUL_N & & NDVI - number of years in mean $(0-3)$ & Calculated & 81 & 933 & 1637 \\
\hline AUG_N & & NDVI - number of years in mean $(0-3)$ & Calculated & 81 & 933 & 1637 \\
\hline SEP_N & & NDVI - number of years in mean $(0-3)$ & Calculated & 81 & 933 & 1637 \\
\hline OCT_N & & NDVI - number of years in mean $(0-3)$ & Calculated & 81 & 933 & 1637 \\
\hline NOV_N & & NDVI - number of years in mean $(0-3)$ & Calculated & 81 & 933 & 1637 \\
\hline DEC_N & & NDVI - number of years in mean $(0-3)$ & Calculated & 81 & 933 & 1637 \\
\hline
\end{tabular}

Table D.11. Model driver 30-year average monthly climate information derived from global sources

\begin{tabular}{|c|c|c|c|c|c|c|}
\hline Variable & Units & Description & Source & \multicolumn{3}{|c|}{ Class } \\
\hline \multicolumn{4}{|c|}{$\begin{array}{l}\text { Monthly TAVE_PIK, TMAX_PIK, etc., climate - } \\
\text { amon variables in } 6 \text { data sets containing average 1961-1990 monthly climate data }\end{array}$} & A & $\mathrm{B}$ & $\mathrm{C}$ \\
\hline SITE_ID & $\mathrm{N} / \mathrm{A}$ & Site ID number based on unique lat/long & Assigned & 81 & 933 & 1637 \\
\hline LAT_DD & Decimal degrees & Latitude $\mathrm{xx} . \mathrm{xx}$ & As given & 81 & 933 & 1637 \\
\hline LONG_DD & Decimal degrees & Longitude $\mathrm{xxx} . \mathrm{xx}$ & As given & 81 & 933 & 1637 \\
\hline YEAR & $1961-1990$ & Year of record & & 81 & 933 & 1637 \\
\hline TYPE & $\begin{array}{l}\text { TAVE, TMAX. } \\
\text { TMIN. PREC, SUN }\end{array}$ & Type of climate variable & $\begin{array}{l}\text { Leemans and } \\
\text { Cramer (extracted } \\
\text { by Cramer) }\end{array}$ & 81 & 933 & 1637 \\
\hline ELEV & $\mathrm{m}$ & Elevation & As given & 81 & $\mathrm{X}$ & $\mathrm{X}$ \\
\hline JAN & $\begin{array}{l}\text { Based on TYPE: }{ }^{\circ} \\
\text { millimeters, } \%\end{array}$ & Climate values for month & Same source & 81 & 933 & 1637 \\
\hline FEB & $\begin{array}{l}\text { Based on TYPE: }{ }^{\circ} \\
\text { millimeters, } \%\end{array}$ & Climate values for month & Same source & 81 & 933 & 1637 \\
\hline MAR & $\begin{array}{l}\text { Based on TYPE: }{ }^{\circ} \text {, } \\
\text { millimeters, } \%\end{array}$ & Climate values for month & Same source & 81 & 933 & 1637 \\
\hline APR & $\begin{array}{l}\text { Based on TYPE: }{ }^{\circ} \text {, } \\
\text { millimeters, } \%\end{array}$ & Climate values for month & Same source & 81 & 933 & 1637 \\
\hline MAY & $\begin{array}{l}\text { Based on TYPE: }{ }^{\circ} \\
\text { millimeters, } \%\end{array}$ & Climate values for month & Same source & 81 & 933 & 1637 \\
\hline JUN & $\begin{array}{l}\text { Based on TYPE: }{ }^{\circ} \text {, } \\
\text { millimeters, } \%\end{array}$ & Climate values for month & Same source & 81 & 933 & 1637 \\
\hline JUL & $\begin{array}{l}\text { Based on TYPE: }{ }^{\circ} \\
\text { millimeters, } \%\end{array}$ & Climate values for month & Same source & 81 & 933 & 1637 \\
\hline AUG & $\begin{array}{l}\text { Based on TYPE: }{ }^{\circ} \\
\text { millimeters, } \%\end{array}$ & Climate values for month & Same source & 81 & 933 & 1637 \\
\hline SEP & $\begin{array}{l}\text { Based on TYPE: }{ }^{\circ} \\
\text { millimeters, } \%\end{array}$ & Climate values for month & Same source & 81 & 933 & 1637 \\
\hline OCT & $\begin{array}{l}\text { Based on TYPE: }{ }^{\circ} \\
\text { millimeters, } \%\end{array}$ & Climate values for month & Same source & 81 & 933 & 1637 \\
\hline $\mathrm{NOV}$ & $\begin{array}{l}\text { Based on TYPE: }{ }^{\circ} \\
\text { millimeters, } \%\end{array}$ & Climate values for month & Same source & 81 & 933 & 1637 \\
\hline DEC & $\begin{array}{l}\text { Based on TYPE: }{ }^{\circ} \\
\text { millimeters, } \%\end{array}$ & Climate values for month & Same source & 81 & 933 & 1637 \\
\hline $\mathrm{ANN}$ & $\begin{array}{l}\text { Based on TYPE: }{ }^{\circ} \text {, } \\
\text { millimeters, } \%\end{array}$ & $\begin{array}{l}\text { Climate statistic for the year: mean(TAVE), } \\
\max (\mathrm{TMAX}) \min (\mathrm{TMIN}), \operatorname{sum}(\mathrm{PREC}) \\
\operatorname{mean}(\mathrm{SUN})\end{array}$ & $\begin{array}{l}\text { Calculated from } 12 \\
\text { months }\end{array}$ & 81 & 933 & 1637 \\
\hline \multicolumn{4}{|c|}{ Five data sets contain climate data described above for each of the climate parameters defined below: } & A & $\mathrm{B}$ & $\mathrm{C}$ \\
\hline TAVE & ${ }^{\circ} \mathrm{C}$ & Temperature - long-term (30 y) monthly average & $\begin{array}{l}\text { Leemans and } \\
\text { Cramer (extracted } \\
\text { by Cramer) }\end{array}$ & & & \\
\hline TMIN & ${ }^{\circ} \mathrm{C}$ & $\begin{array}{l}\text { Temperature - long-term ( } 30 \text { y) average monthly } \\
\text { minimum }\end{array}$ & Same source & & & \\
\hline TMAX & ${ }^{\circ} \mathrm{C}$ & $\begin{array}{l}\text { Temperature - long-term ( } 30 \text { y) average monthly } \\
\text { maximum }\end{array}$ & Same source & & & \\
\hline PREC & Millimeters & $\begin{array}{l}\text { Precipitation - long-term ( } 30 \mathrm{y}) \text { average annual } \\
\text { total }\end{array}$ & Same source & & & \\
\hline SUN & $\%$ & $\begin{array}{l}\text { Sunshine - long-term ( } 30 \mathrm{y}) \text { average percentage } \\
\text { of hours of sunshine per daylight hours }\end{array}$ & Same source & & & \\
\hline
\end{tabular}


Table D.12. Model driver atmospheric carbon dioxide information derived from global sources

\begin{tabular}{|c|c|c|c|c|c|c|}
\hline Variable & Units & Description & Source & \multicolumn{3}{|c|}{ Class } \\
\hline \multicolumn{4}{|c|}{ CO2_95 - Global Atmospheric CO2 Information } & $\mathrm{A}$ & $\mathrm{B}$ & $\mathrm{C}$ \\
\hline YEAR & & Year (1901-1995) & & 95 & $\mathrm{X}$ & $\mathrm{X}$ \\
\hline $\mathrm{CO} 2$ & ppmv & Global Atmospheric $\mathrm{CO} 2$ estimates & $\begin{array}{l}\text { Law Dome/Mauna } \\
\text { Loa (Keeling et al.) } \\
\text { provided by CDIAC }\end{array}$ & 95 & $\mathrm{X}$ & $\mathrm{X}$ \\
\hline
\end{tabular}

Table D.13. Model driver 95-year transient climate information derived from global sources

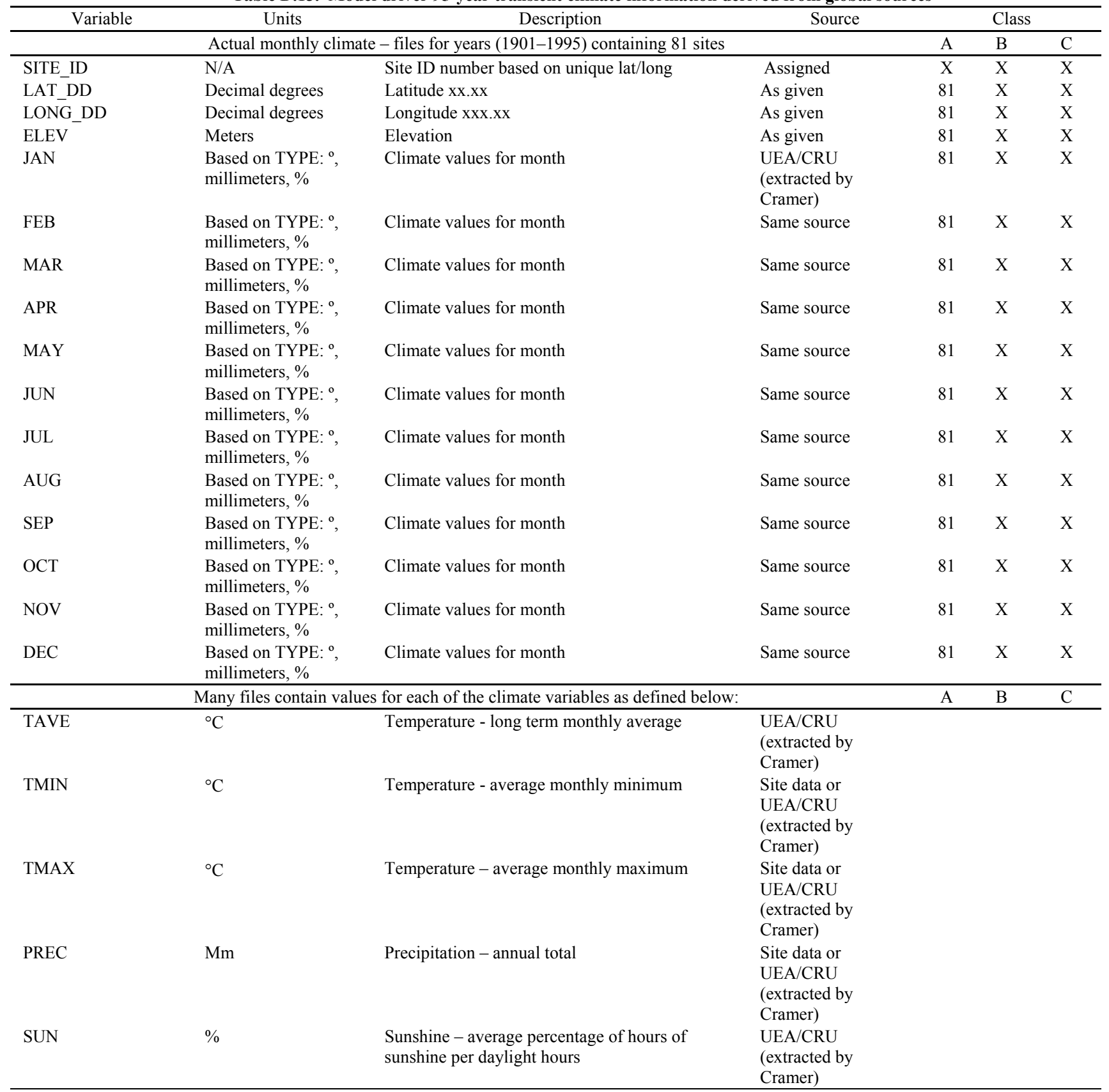


Table D.14. Model validation NPP information derived from site-specific sources

\begin{tabular}{|c|c|c|c|c|c|c|}
\hline Variable & Units & Description & Source & & Class & \\
\hline & & NPP_xxx.csv & & A & $\mathrm{B}$ & $\mathrm{C}$ \\
\hline MEAS_ID & $\mathrm{N} / \mathrm{A}$ & Unique measurement ID number & Assigned & 162 & 2363 & 2696 \\
\hline SITE_ID & N/A & Site ID number based on lat/long & Assigned & 162 & 2363 & 2696 \\
\hline LAT_DD & Decimal degrees & Latitude xx.xx, southern latitudes are negative & As given & 162 & 2363 & 2696 \\
\hline LONG_DD & Decimal degrees & $\begin{array}{l}\text { Longitude } \mathrm{xxx} . \mathrm{xx} \text {, western longitudes are } \\
\text { negative }\end{array}$ & As given & 162 & 2363 & 2696 \\
\hline LAT_OLD & Decimal degrees & Latitude $\mathrm{xx} . \mathrm{xx}$, southern latitudes are negative & As given & 162 & 2363 & $\mathrm{X}$ \\
\hline LONG_OLD & Decimal degrees & $\begin{array}{l}\text { Longitude xxx.xx, western longitudes are } \\
\text { negative }\end{array}$ & As given & 162 & 2363 & $\mathrm{X}$ \\
\hline ELEV_GIV & Meters & Elevation for site & As given & 98 & 1174 & $\mathrm{X}$ \\
\hline ELEV_DEM & Meters & $\begin{array}{l}\text { Elevation extracted from a global DEM }(1 \mathrm{~km} \\
\text { resolution) }\end{array}$ & $\begin{array}{l}\text { Extracted from a } \\
\text { global DEM (1 km } \\
\text { resolution) }\end{array}$ & $\mathrm{X}$ & 2346 & 2696 \\
\hline SITE_OLD & $\mathrm{N} / \mathrm{A}$ & Site identifier & As given & $\mathrm{X}$ & 1438 & $\mathrm{X}$ \\
\hline SOURCE & $\mathrm{N} / \mathrm{A}$ & Source of the NPP data name or code & As assigned & 162 & 2363 & 2696 \\
\hline COUNTRY & $\mathrm{N} / \mathrm{A}$ & Country name & As given & 162 & 2363 & $\mathrm{X}$ \\
\hline BIOMENEW & $\mathrm{N} / \mathrm{A}$ & Biome type, standardized to EMDI classes & $\begin{array}{l}\text { Based on Biome, } \\
\text { Species, Veg_type }\end{array}$ & 162 & 2363 & $\mathrm{X}$ \\
\hline SUBBIOME & N/A & Sub Biome, e.g., conifer, decid. & As given & $\mathrm{X}$ & 1465 & $\mathrm{X}$ \\
\hline VEG_TYPE & $\mathrm{N} / \mathrm{A}$ & Vegetation type as given, somewhat standardized & As given & 162 & 1399 & $\mathrm{X}$ \\
\hline SPECIES & N/A & Dominant species & As given & 145 & 1425 & $\mathrm{X}$ \\
\hline TEMP_ANN & ${ }^{\circ} \mathrm{C}$ & Annual average temperature & $\begin{array}{l}\text { Extracted from global } \\
\text { gridded climate }\end{array}$ & 131 & 607 & 2696 \\
\hline PREC_ANN & Millimeters & Annual total precipitation & $\begin{array}{l}\text { Extracted from global } \\
\text { gridded climate }\end{array}$ & 147 & 787 & 2696 \\
\hline ANPP_C & $\mathrm{gC} / \mathrm{m}^{2} / \mathrm{y}$ & Aboveground NPP & As given & 162 & 1484 & 2477 \\
\hline $\mathrm{BNPP} C \mathrm{C}$ & $\mathrm{gC} / \mathrm{m}^{2} / \mathrm{y}$ & Below ground NPP & As given & 117 & 601 & $\mathrm{X}$ \\
\hline TNPP_C & $\mathrm{gC} / \mathrm{m}^{2} / \mathrm{y}$ & Total NPP & As given & 162 & 1486 & 2695 \\
\hline REFERENC & $\mathrm{N} / \mathrm{A}$ & Reference for the NPP value & As given & 129 & 2358 & $\mathrm{X}$ \\
\hline YEAR_REF & $\mathrm{N} / \mathrm{A}$ & Year of the reference & As given & 81 & 861 & $\mathrm{X}$ \\
\hline
\end{tabular}

Table D.15. Model validation outlier flags derived from site-specific reviews

\begin{tabular}{|c|c|c|c|c|c|c|}
\hline Variable & Units & Description & Source & & Class & \\
\hline & & FLAGS_xxx.csv & & A & $\mathrm{B}$ & $\mathrm{C}$ \\
\hline MEAS_ID & $\mathrm{N} / \mathrm{A}$ & Unique measurement ID number & Assigned & 162 & 2363 & 2696 \\
\hline SITE_ID & N/A & Site ID number based on lat/long & Assigned & 162 & 2363 & 2696 \\
\hline $\mathrm{LAT}_{-} \mathrm{DD}$ & Decimal degrees & Latitude xx.xx, southern latitudes are negative & As given & 162 & 2363 & 2696 \\
\hline LONG_DD & Decimal degrees & $\begin{array}{l}\text { Longitude } \mathrm{xxx} . \mathrm{xx} \text {, western longitudes are } \\
\text { negative }\end{array}$ & As given & 162 & 2363 & 2696 \\
\hline ELEV & Meters & Elevation for site & As given & 98 & 2346 & 2696 \\
\hline SOURCE & N/A & Source of the NPP data name or code & As assigned & 162 & 2363 & 2696 \\
\hline BIOMENEW & $\mathrm{N} / \mathrm{A}$ & Biome type, standardized to 21 EMDI classes & $\begin{array}{l}\text { Based on Biome, } \\
\text { Species, Veg_type }\end{array}$ & 162 & 2363 & 2696 \\
\hline BIOME2 & N/A & Biome type, consolidated into 14 EMDI classes & $\begin{array}{l}\text { Based on } \\
\text { BIOMENEW, }\end{array}$ & 162 & 2363 & $\mathrm{X}$ \\
\hline TAVE & ${ }^{\circ} \mathrm{C}$ & Annual average temperature & $\begin{array}{l}\text { Extracted from global } \\
\text { gridded climate }\end{array}$ & 131 & 2346 & 2696 \\
\hline PREC & Millimeters & Annual total precipitation & $\begin{array}{l}\text { Extracted from global } \\
\text { gridded climate }\end{array}$ & 147 & 2346 & 2696 \\
\hline ANPP_C & $\mathrm{gC} / \mathrm{m}^{2} / \mathrm{y}$ & Aboveground NPP & As given & 162 & 1484 & 2477 \\
\hline $\mathrm{BNPP}_{-}^{-} \mathrm{C}$ & $\mathrm{gC} / \mathrm{m}^{2} / \mathrm{y}$ & Below ground NPP & As given & 117 & 601 & X \\
\hline $\mathrm{TNPP}_{-} \mathrm{C}$ & $\mathrm{gC} / \mathrm{m}^{2} / \mathrm{y}$ & Total NPP & As given & 162 & 1486 & 2695 \\
\hline
\end{tabular}


Table D.15 (continued)

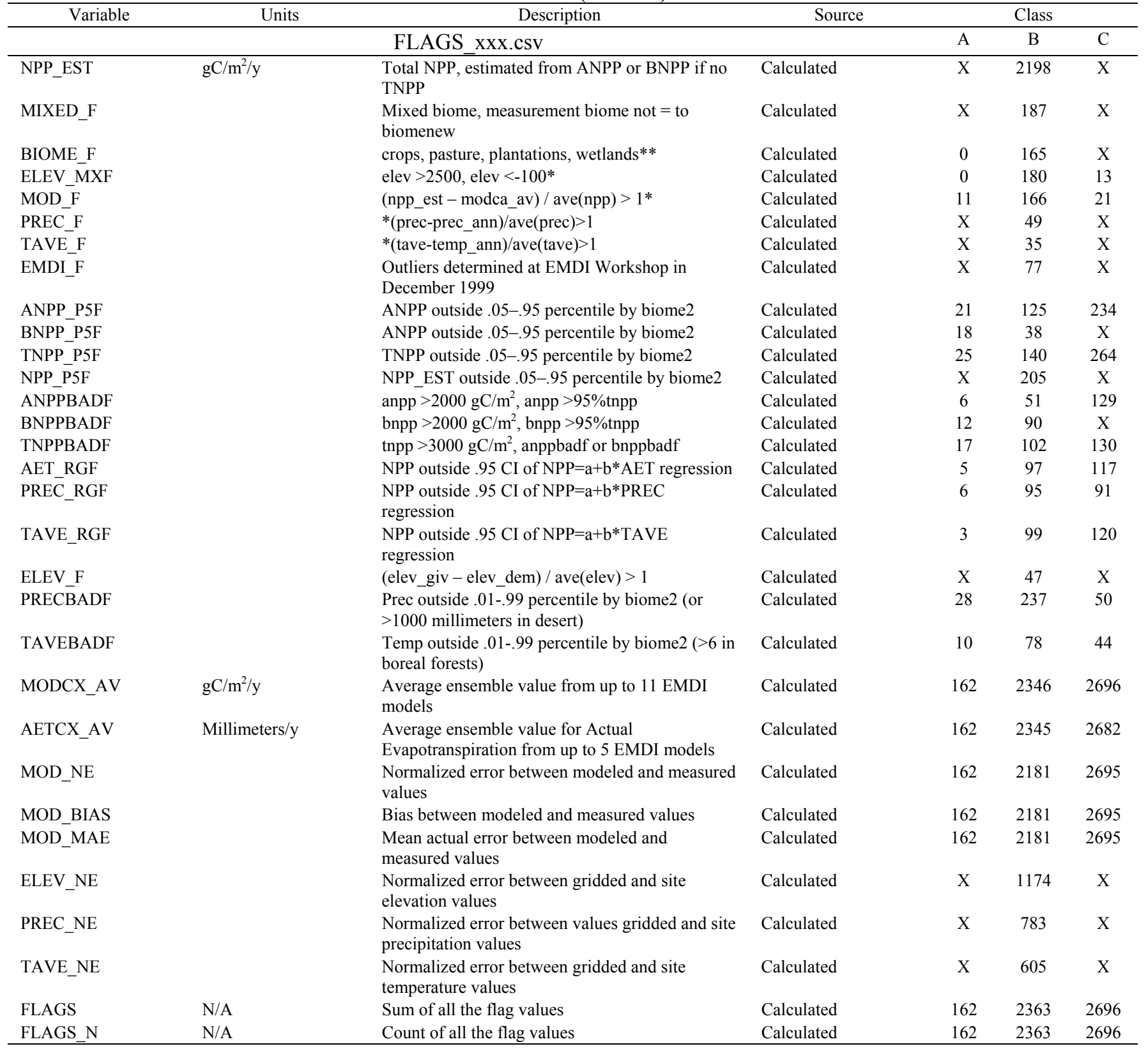

Table D.16. Model validation mean NPP information derived from site-specific data that passed outlier analysis

\begin{tabular}{|c|c|c|c|c|c|c|}
\hline Variable & Units & Description & Source & \multicolumn{3}{|c|}{ Class } \\
\hline & & MEANS_xxx.csv & & $\mathrm{A}$ & $\mathrm{B}$ & $\mathrm{C}$ \\
\hline SITE_ID & N/A & $\begin{array}{l}\text { Site ID number (1-149) based on } \\
\text { lat/long }\end{array}$ & Assigned & 81 & 933 & 1637 \\
\hline LAT_DD & Decimal degrees & $\begin{array}{l}\text { Latitude xx.xx, southern latitudes are } \\
\text { negative }\end{array}$ & As given & 81 & 933 & 1637 \\
\hline LONG_DD & Decimal degrees & $\begin{array}{l}\text { Longitude xxx.xx, western } \\
\text { longitudes are negative }\end{array}$ & As given & 81 & 933 & 1637 \\
\hline ELEV & Meters & Elevation for site & $\begin{array}{l}\text { As given or, if not } \\
\text { given, from DEM }\end{array}$ & 54 & 933 & 1637 \\
\hline ELEV_N & N/A & $\begin{array}{l}\text { Number of elevation measurements } \\
\text { for this site }\end{array}$ & Calculated & 54 & 933 & 1637 \\
\hline
\end{tabular}


Table D.16 (continued)

\begin{tabular}{|c|c|c|c|c|c|c|}
\hline Variable & Units & Description & Source & \multicolumn{3}{|c|}{ Class } \\
\hline & & MEANS_xxx.csv & & A & $\mathrm{B}$ & $\mathrm{C}$ \\
\hline BIOME2 & N/A & $\begin{array}{l}\text { Biome type, consolidated into } 14 \\
\text { EMDI classes }\end{array}$ & $\begin{array}{l}\text { Based on } \\
\text { BIOMENEW, }\end{array}$ & 81 & $\mathrm{X}$ & $\mathrm{X}$ \\
\hline BIOME & N/A & $\begin{array}{l}\text { Biome type, consolidated into } 4 \\
\text { EMDI classes }\end{array}$ & As given & $\mathrm{X}$ & $\mathrm{X}$ & 1637 \\
\hline TAVE_N & N/A & $\begin{array}{l}\text { Number of temperature readings for } \\
\text { this site }\end{array}$ & Calculated & 67 & 933 & 1637 \\
\hline PREC & Millimeters & Annual total precipitation & $\begin{array}{l}\text { Extracted from global } \\
\text { gridded climate }\end{array}$ & 72 & 933 & 1637 \\
\hline PREC_N & N/A & $\begin{array}{l}\text { Number of precipitation values for } \\
\text { this site }\end{array}$ & Calculated & 72 & 933 & 1637 \\
\hline BNPP_C & $\mathrm{gC} / \mathrm{m}^{2} / \mathrm{y}$ & $\begin{array}{l}\text { Below ground NPP - mean of } \\
\text { several published estimates }\end{array}$ & Calculated & 72 & 192 & $X$ \\
\hline BNPP_N & N/A & $\begin{array}{l}\text { Number of published BNPP } \\
\text { measurements for this site }\end{array}$ & Calculated & 72 & 192 & $\mathrm{X}$ \\
\hline TNPP_C & $\mathrm{gC} / \mathrm{m}^{2} / \mathrm{y}$ & $\begin{array}{l}\text { Total NPP - mean of several } \\
\text { published estimates }\end{array}$ & Calculated & 81 & 671 & 1636 \\
\hline TNPP_N & N/A & $\begin{array}{l}\text { Number of published TNPP } \\
\text { measurements for this site }\end{array}$ & Calculated & 81 & 671 & 1636 \\
\hline NPP_EST & $\mathrm{gC} / \mathrm{m}^{2} / \mathrm{y}$ & $\begin{array}{l}\text { Total NPP, estimated from ANPP or } \\
\text { BNPP if no TNPP }\end{array}$ & Calculated & $\mathrm{X}$ & 933 & $\mathrm{X}$ \\
\hline NPP_N & N/A & $\begin{array}{l}\text { Number of NPP_EST estimates for } \\
\text { this site }\end{array}$ & Calculated & $\mathrm{X}$ & 933 & $\mathrm{X}$ \\
\hline FLAGS & N/A & Sum of all the flag values & Calculated & 81 & 933 & 1637 \\
\hline FLAG_N & N/A & Number of all the flag values & Calculated & 81 & 933 & 1637 \\
\hline TAVE_MAX & ${ }^{\circ} \mathrm{C}$ & Maximum temperature for this site & Calculated & 67 & 933 & 1637 \\
\hline PREC_MAX & Millimeters & Maximum precipitation for this site & Calculated & 72 & 933 & 1637 \\
\hline ELEV_MAX & Meters & Maximum elevation for this site & Calculated & 54 & 933 & 1637 \\
\hline ANPP_MAX & $\mathrm{gC} / \mathrm{m}^{2} / \mathrm{y}$ & $\begin{array}{l}\text { Aboveground NPP - maximum of } \\
\text { several published estimates }\end{array}$ & Calculated & 81 & 465 & 1461 \\
\hline BNPP_MAX & $\mathrm{gC} / \mathrm{m}^{2} / \mathrm{y}$ & $\begin{array}{l}\text { Below ground NPP - maximum of } \\
\text { several published estimates }\end{array}$ & Calculated & 72 & 192 & $\mathrm{X}$ \\
\hline TNPP_MAX & $\mathrm{gC} / \mathrm{m}^{2} / \mathrm{y}$ & $\begin{array}{l}\text { Total NPP - maximum of several } \\
\text { published estimates }\end{array}$ & Calculated & 81 & 671 & 1636 \\
\hline NPP_MAX & $\mathrm{gC} / \mathrm{m}^{2} / \mathrm{y}$ & $\begin{array}{l}\text { NPP_EST - maximum of several } \\
\text { estimates from ANPP or BNPP if no } \\
\text { TNPP }\end{array}$ & Calculated & $\mathrm{X}$ & 933 & $\mathrm{X}$ \\
\hline MOD_MAX & $\mathrm{gC} / \mathrm{m}^{2} / \mathrm{y}$ & Maximum model output of NPP & Calculated & 81 & 933 & 1637 \\
\hline AET_MAX & Millimeters/y & Maximum model output of AET & Calculated & 81 & 932 & \\
\hline FLAG_MAX & N/A & $\begin{array}{l}\text { Maximum number of flags } \\
\text { associated with a site }\end{array}$ & Calculated & 81 & 933 & 1637 \\
\hline TAVE_MIN & ${ }^{\circ} \mathrm{C}$ & Minimum temperature for this site & Calculated & 67 & 933 & 1637 \\
\hline PREC_MIN & Millimeters & Minimum precipitation for this site & Calculated & 72 & 933 & 1637 \\
\hline ELEV_MIN & Meters & Minimum elevation for this site & Calculated & 54 & 933 & 1637 \\
\hline
\end{tabular}


Table D.16 (continued)

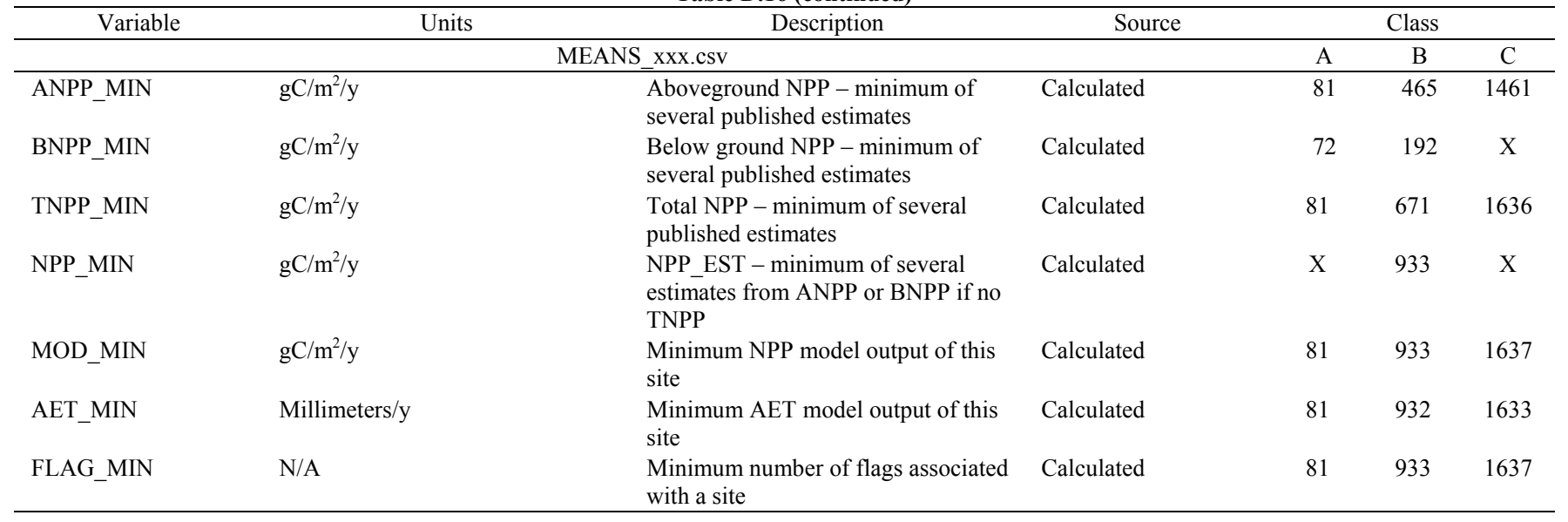

Table D.17. Model validation driver information derived from a variety of sources

\begin{tabular}{|c|c|c|c|c|c|c|}
\hline Variable & Units & Description & Source & \multicolumn{3}{|c|}{ Class } \\
\hline & & DRIVER_xxx.csv & & $\mathrm{A}$ & $\mathrm{B}$ & $\mathrm{C}$ \\
\hline SITE_ID & N/A & Site ID number based on lat/long & Assigned & $\bar{X}$ & 933 & $\mathrm{X}$ \\
\hline LAT_DD & Decimal degrees & Latitude $x x . x x$, southern latitudes are negative & As given & $\mathrm{X}$ & 933 & $\mathrm{X}$ \\
\hline LONG_DD & Decimal degrees & $\begin{array}{l}\text { Longitude xxx.xx, western longitudes are } \\
\text { negative }\end{array}$ & As given & $\mathrm{X}$ & 933 & $\mathrm{X}$ \\
\hline ELEV_GIV & Meters & Elevation for site & As given & $\mathrm{X}$ & 468 & $\mathrm{X}$ \\
\hline ELEV_DEM & Meters & Elevation extracted from a global DEM & $\begin{array}{l}\text { Global DEM }(1 \mathrm{~km} \\
\text { resolution) }\end{array}$ & $\mathrm{X}$ & 200 & $\mathrm{X}$ \\
\hline ELEV_G_N & N/A & Number of elevation measurements for this site & Calculated & $\mathrm{X}$ & 468 & $\mathrm{X}$ \\
\hline ELEV_D_N & N/A & Number of elevation measurements for this site & Calculated & $\mathrm{X}$ & 200 & $\mathrm{X}$ \\
\hline SITE_OLD & $\mathrm{N} / \mathrm{A}$ & Site identifier & As given & $\mathrm{X}$ & 706 & $\mathrm{X}$ \\
\hline SOURCE & $\mathrm{N} / \mathrm{A}$ & Source of the NPP data name or code & As assigned & $\mathrm{X}$ & 933 & $\mathrm{X}$ \\
\hline COUNTRY & N/A & Country name & As given & $\mathrm{X}$ & 933 & $\mathrm{X}$ \\
\hline BIOMENEW & $\mathrm{N} / \mathrm{A}$ & Biome type, standardized to EMDI classes & $\begin{array}{l}\text { Based on Biome, } \\
\text { Species, Veg_type }\end{array}$ & $\mathrm{X}$ & 933 & $\mathrm{X}$ \\
\hline SUBBIOME & N/A & Sub Biome, e.g., conifer, decid. & As given & $\mathrm{X}$ & 933 & $\mathrm{X}$ \\
\hline VEG_TYPE & N/A & Vegetation type as given, somewhat standardized & As given & $\mathrm{X}$ & 688 & $\mathrm{X}$ \\
\hline SPECIES & N/A & Dominant species & As given & $\mathrm{X}$ & 704 & $\mathrm{X}$ \\
\hline SUBBIOME & N/A & Sub Biome, e.g., conifer, decid. & As given & $\mathrm{X}$ & 582 & $\mathrm{X}$ \\
\hline REFERENC & N/A & Reference & As given & $\mathrm{X}$ & 933 & $\mathrm{X}$ \\
\hline YEAR_REF & N/A & Year of reference & As given & $\mathrm{X}$ & 202 & $\mathrm{X}$ \\
\hline
\end{tabular}


ORNL/TM-2001/196

\section{INTERNAL DISTRIBUTION}

1. J. S. Amthor

2. R. B. Cook

3. D. E. Fowler

4. P. J. Hanson

5. W. F. Harris

6. S. G. Hildebrand

7. M. A. Huston

8. G. K. Jacobs

9. A. W. King

10. G. Marland
11-20. R. J. Olson

21. W. M. Post

22-31. J. M. O. Scurlock

32. L. D. Voorhees

33. S. Wullschleger

34. Central Research Library

35-37. ESD Library

38. Laboratory Records Department

39. Laboratory Records, ORNL-RC

\section{EXTERNAL DISTRIBUTION}

40. Michael Apps, Department of Natural Resources, Canadian Forest Service, $5320122^{\text {nd }}$ Street, Edmonton, Alberta, T6H 3S5, Canada

41. Dominique Bachelet, Department of Bioresource Engineering, Oregon State University, 2905 Hampton Drive SW, Tumwater, WA 98512

42. Dennis Baldocchi, Ecosystem Science Division and Berkeley Atmospheric Science Center, Department of Environmental Science, Policy, and Management, 151 Hilgard Hall, University of California, Berkeley, Berkeley, CA 94720

43. Richard Birdsey, Northern Global Change Research Program, USDA Forest Service, Newtown Square Corporate Campus, 11 Campus Boulevard, Suite 200, Newtown Square, PA 19073

44. Victor Brovkin, Climate Systems Research Department, Potsdam Institute for Climate Impact Research, P.O. Box 601203, 14412 Potsdam, Germany

45. Sandra Brown, Winrock International, 1621 N Kent Street, Suite 1200, Arlington, VA 22209

46. Ingrid C. Burke, Department of Forest Sciences, 206 Natural Resources, Colorado State University, Fort Collins, CO 80523

47. Josep Canadell, GCTE International Project Office, CSIRO Sustainable Ecosystems, P.O. Box 284, Canberra, ACT, 2601, Australia

48. Josef Cihlar, Canada Centre for Remote Sensing, Energy Mines \& Resources Canada, 588 Booth Street, $4^{\text {th }}$ Floor, Ottawa, Canada K1A 0 Y7

49. Deborah Clark, Department of Biology, University of Missouri, St. Louis, INTERLINK-341, P.O. Box 02-5635, Miami, FL 33152

50. Warren Cohen, Forestry Sciences Laboratory, United States Forest Service, 3200 SW Jefferson Way, Corvallis, OR 97332 
51. Michael Coughenour, Natural Resources Ecology Laboratory, Colorado State University, Fort Collins, CO 80523

52. Wolfgang Cramer, Potsdam Institute for Climate Impact Research, P.O. Box 601203, Telegrafenberg, D-14412, Potsdam, Germany

53. Roger C. Dahlman, U.S. Department of Energy, SC-74, 19901 Germantown Road, Germantown, MD 20874-1290

54. Ken Day, Department of Natural Resources, Climate Impacts and Grazing Systems, 80 Meiers Road, Indooroopilly, Brisbane, Queensland, 4086, Australia

55. Ruth S. DeFries, Department of Geography, Room 1127, Le Frak Hall, University of Maryland, College Park, MD 20742-8225

56. Jerry Elwood, Acting Director, Environmental Sciences Division, ER-74, Department of Energy, 19901 Germantown Road, Germantown, MD 20874

57. Gerd Esser, Institute for Plant Ecology, Justus-Liebig-University, Heinrich-Buff-Ring 38, D35292 Giessen, Germany

58. Christopher Field, Carnegie Institution of Washington, 290 Panama Street, Stanford, CA 94305

59. Jonathan A. Foley, Climate, People, and Environment Program, Institute for Environmental Studies, University of Wisconsin, 1225 West Dayton Street, Madison, WI 53706

60. Tagir Gilmanov, Department of Biology/Microbiology, AgH 310, Box 2207B, South Dakota State University, Brookings, SD 57007-2142

61. Scott Goetz, Department of Geography, University of Maryland, College Park, MD 20742-8225

62. James Gosz, Department of Biology, University of New Mexico, Albuquerque, NM 87131-1091

63. Stith T. Gower, Forest Ecosystem Ecology Program, Department of Forestry, 1630 Linden Drive, University of Wisconsin, Madison, WI 53706

64. Kathy Hibbard, Climate Change Research Center, Institute for the Study of Earth, Oceans, and Space, University of New Hampshire, Morse Hall, 39 College Road, Durham, NH 03824-3525

65. Elisabeth Holland, Atmospheric Chemistry Division, National Center for Atmospheric Research, 1850 Table Mesa Drive, P.O. Box 3000, Boulder, CO 80307-3000

66. Robert B. Jackson, Department of Biology and Nicholas School of the Environment, Box 90340, Phytotron Building, Duke University, Durham, NC 27708

67. Jennifer Jenkins, Research Forester, USDA Forest Service, Northern Global Change Program, 5 Radnor Corporate Center, Suite 200, 100 Matsonford Road, Radnor, PA 19087

68. Jinjun Ji, Institute of Atmospheric Physics, Chinese Academy of Sciences, Beijing, 100029, China 
69. Keri Johnson, 19 Clark Place, Oak Ridge, TN 37830

70. Chris Justice, University of Virginia, Department of Environmental Sciences, Science Clark Hall, Charlottesville, VA 22903

71. Joerg Kaduk, Department of Geography, University of Leicester, Leicester LE1 7RH, England, UK

72. David Kicklighter, The Ecosystems Center, Marine Biological Laboratory, 7 MBL Street, Woods Hole, MA 02543

73. Timothy G. F. Kittel, National Center for Atmospheric Research, P.O. Box 3000, Boulder, CO 80307

74. Steven Klooster, Ecosystem Science and Technology Branch, NASA Ames Research Center, Mail Stop 242-4, Moffett Field, CA 94035

75. Alan K. Knapp, Division of Biology, Kansas State University, Manhattan, KS 66506

76. Olga Krankina, Department of Forest Science, Oregon State University, Corvallis, OR 97330

77. Chris Kucharik, Department of Soil Science, University of Wisconsin-Madison, 1525

Observatory Drive, Madison, WI 53706

78. William Lauenroth, Department of Range Science, NREL, Colorado State University, Fort Collins, CO 80523

79. Beverly E. Law, 328 Richardson Hall, College of Forestry, Oregon State University, Corvallis, OR 97331

80. Yingpeng Li, Institute of Atmospheric Physics, Chinese Academy of Sciences, Chaoyang District, Beijing, 100029, China

81. Sune Linder, Department of Ecology and Environmental Research, Swedish University of Agricultural Sciences, P.O. Box 7072, S-75007 Uppsala, Sweden

82. Ross McMurtrie, School of Biological Science, University of New South Wales, BioScience Building, Sydney, 2052 Australia

83. Berrien Moore III, Morse Hall, Institute for the Study of Earth, Oceans, and Space, University of New Hampshire, Durham, NH 03824

84. Jeff Morisette, NASA GSFC, University of Maryland, Code 923, Greenbelt, MD 20771

85. Jian Ni, Max Planck Institute for Biogeochemistry, Carl Zeiss Promenade 10, P.O. Box 1001 64, D-07701, Jena, Germany

86. Office of Assistant Manager for Energy Research and Development, Department of Energy, Oak Ridge Operations, P.O. Box 2001, Oak Ridge, TN 37831-8600 
87. Office of Scientific and Technical Information, P.O. Box 62, Oak Ridge, TN 37831

88. Dennis Ojima, Natural Resource Ecology Laboratory, Colorado State University, Fort Collins, CO 80523

89. Jerry S. Olson, 508 Eblen Cave Road, Lenoir City, TN 37771

90. William Parton, Natural Resource Ecology Laboratory, Colorado State University, Fort Collins, CO 80523

91-100. Stephen D. Prince, Department of Geography, LeFrak Hall, University of Maryland, College Park, MD 20742-8225

101. Jeffrey L. Privette, NASA Biospheric Sciences, Code 923, Goddard Space Flight Center, Greenbelt, MD 20771

102. James Reichman, National Center for Ecological Analysis and Synthesis, 735 State Street, Suite 300, Santa Barbara, CA 93101-3351

103. Steve Running, School of Forestry, University of Montana, Missoula, MT 59812

104. H. Jochen Schenk, Department of Biology, Box 90338, Duke University, Durham, NC 27708

105. David Schimel, Ecosystem Dynamics and the Atmosphere, Climate and Global Dynamics Division, National Center for Atmospheric Research, Boulder, CO 80307

106. Robert Scholes, CSIR, P.O. Box 395, Pretoria 0001, South Africa

107. Hank Shugart, Department of Environmental Science, University of Virginia, Charlottesville, VA 22903

108. Will Steffen, IGBP Secretariat, Royal Swedish Academy of Sciences, Box 50005, S-104 05 Stockholm, Sweden

109. Philippe M. Teillet, Canada Centre for Remote Sensing, 588 Booth Street, Ottawa, Ontario, K1A 0Y7, Canada

110. Peter Thornton, Climate and Global Dynamics Division, National Center for Atmospheric Research, 1850 Table Mesa Drive, P.O. Box 3000, Boulder, CO 80307-3000

111. Larry Tieszen, EROS Data Center, US Geological Survey, Sioux Falls, SD 57198

112. David P. Turner, Forest Science Department, Oregon State University, Corvallis, OR 97331

113. John Vande Castle, University of New Mexico, 801 University Boulevard SE, Suite 104, Albuquerque, NM 87106

114. Charles Vorosmarty, Complex System Research Center, University of New Hampshire, Durham, NH 03824 
115. Diane E. Wickland, Manager, Terrestrial Ecology Program, NASA Code YS, 300 E Street, SW, Washington, DC 20546

116. Curtis Woodcock, Department of Geography, Boston University, 675 Commonwealth Avenue, Boston, MA 02215

117. Xinshi Zhang, Institute of Botany, Chinese Academy of Sciences, 20 Nanxincun XiangShan, Beijing, 100093, PR China

118. Daolan Zheng, Research Associate, Department of Geography, University of Maryland, College Park, MD 20742 